\title{
\#USGS
}

science for a changing world

In cooperation with Monroe County Department of Health

\section{Water Resources of Monroe} County, New York, Water Years 1997-99, with Emphasis on Water Quality in the Irondequoit Creek Basin

Atmospheric Deposition, Ground Water, Streamflow, Trends in Water Quality, and Chemical Loads to Irondequoit Bay

Water-Resources Investigations Report 02-4221

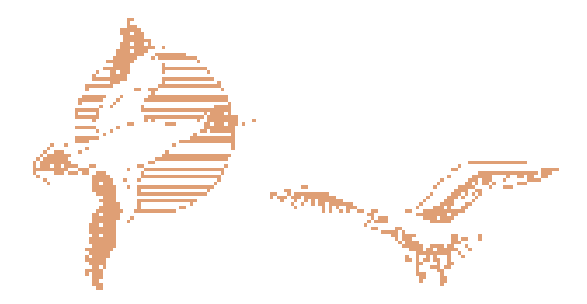


This page has been left blank intentionally. 


\section{Water Resources of Monroe County, New York, Water Years 1997-99, with Emphasis on Water Quality in the Irondequoit Creek Basin}

\section{Atmospheric Deposition, Ground Water, Streamflow,}

Trends in Water Quality, and Chemical Loads to Irondequoit Bay

BY DONALD A. SHERWOOD

U.S. GEOLOGICAL SURVEY

Water-Resources Investigations Report 02-4221

In cooperation with

MONROE COUNTY DEPARTMENT OF HEALTH 


\section{U.S. DEPARTMENT OF THE INTERIOR GAIL NORTON, Secretary}

U.S. GEOLOGICAL SURVEY

Charles G. Groat, Director

Any use of trade, product, or firm names in this publication is for descriptive purposes only and does not imply

endorsement by the U.S. Government

For additional information

write to:

Subdistrict Chief

U.S. Geological Survey

30 Brown Road

Ithaca, NY 14850
Copies of this report can be purchased from:

U.S. Geological Survey Branch of Information Services

Box 25286

Denver, CO 80225 


\section{CONTENTS}

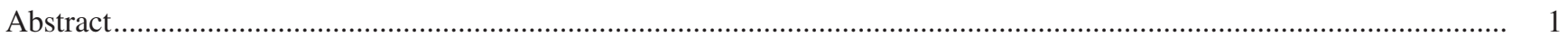

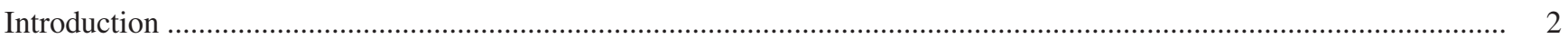

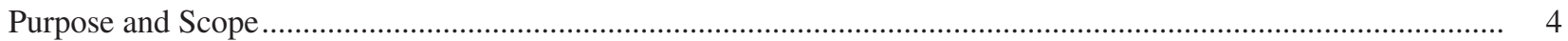

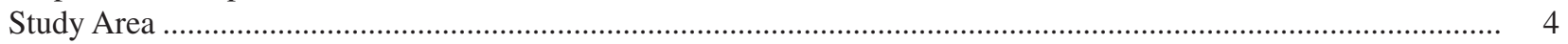

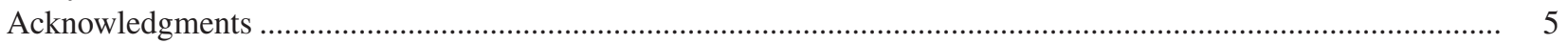

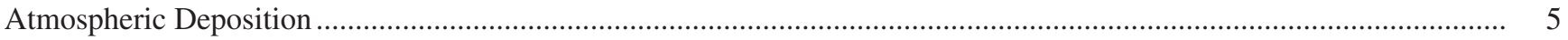

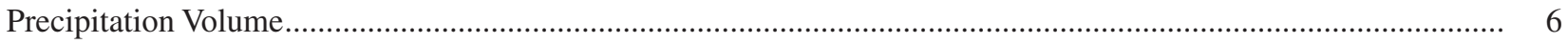

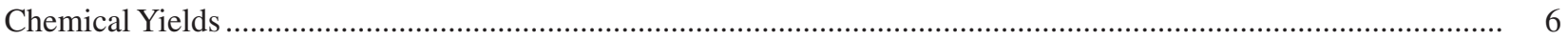

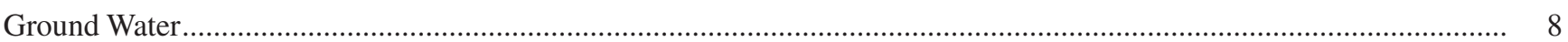

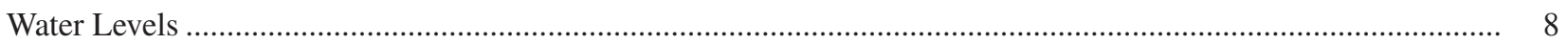

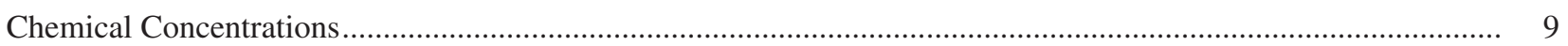

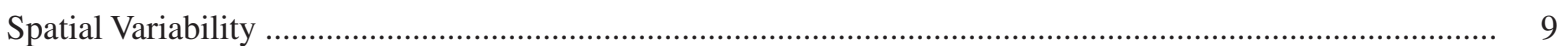

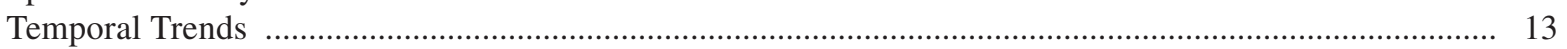

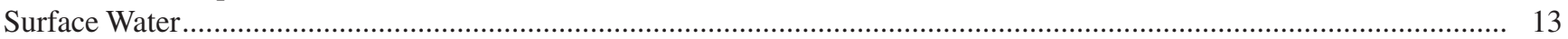

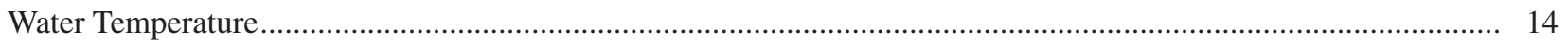

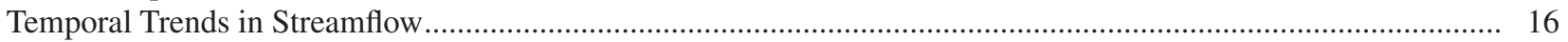

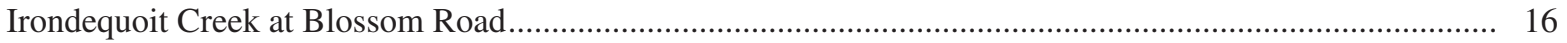

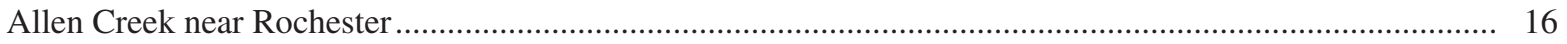

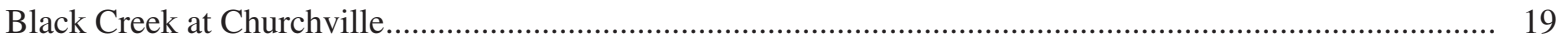

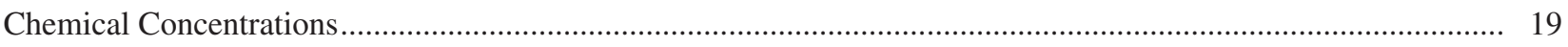

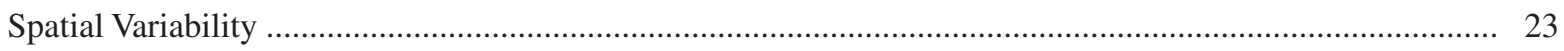

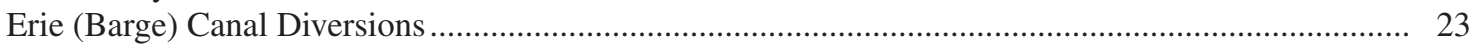

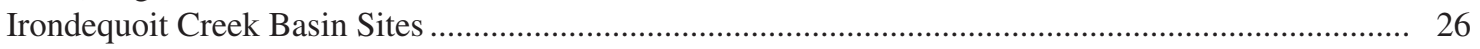

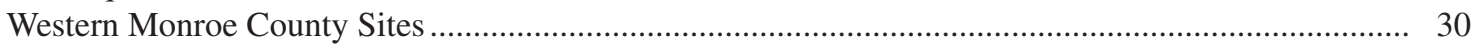

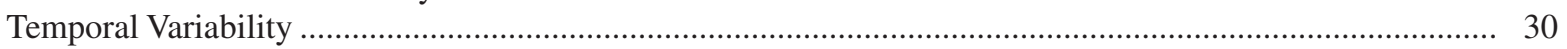

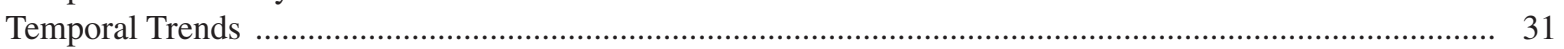

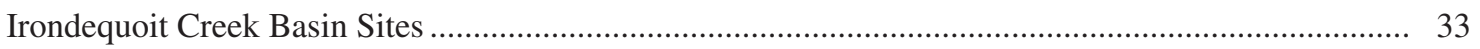

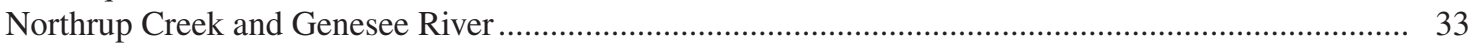

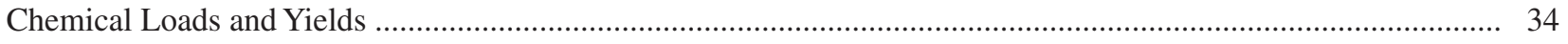

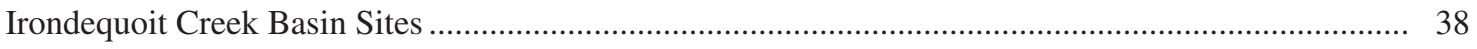

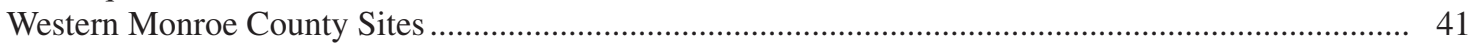

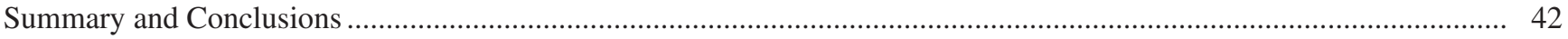

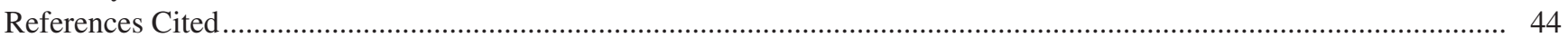

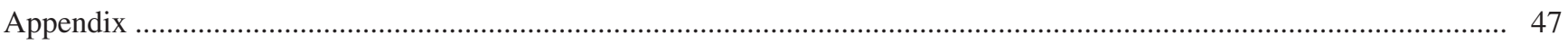

\section{FIGURES}

1. Map showing principal geographic features of Monroe County, N.Y. and locations of streamflow-gaging stations in study area

2. Map showing locations of streamflow-gaging stations, canal-diversion sites, and atmospheric-deposition collection sites within the Irondequoit Creek basin

3. Bar graph showing ammonia in atmospheric deposition at Mendon Ponds County Park. A. Annual yield of ammonia to the Irondequoit Creek basin 1984-99. B. Mean monthly concentration of ammonia in bulk atmospheric deposition

4. Graph showing monthly concentration of dissolved ammonia in bulk atmospheric deposition at Mendon Ponds County Park and locally weighted scatterplot smooth (LOWESS) trend line 1984-99..............................................

5. Map showing locations of observation wells in Ellison Park . 
6. Hydrographs showing water levels in Ellison Park wells, 1985-99

7. Plot of mean monthly water levels at wells Mo 2 and Mo 3, for 1997-99, with mean monthly, maximum, and minimum water levels for 1985-96

8. Bar graphs showing median concentrations of selected constituents in Ellison Park wells for period of record through 1996 and for 1997-99.

9. Bar plot of monthly water-temperature range and mean monthly water temperature at four sites in the Irondequoit Creek basin and Northrup Creek, water years 1997-99.

10. Daily mean water temperatures at four sites in the Irondequoit Creek basin and Northrup Creek, water years 1997-99.

11. Monthly mean flows of three streams in Monroe County, N.Y., water years 1997, 1998, and 1999, in relation to normal range (flows between the 25 th and 75 th percentile) for period of record: A. Irondequoit Creek at Blossom Road. B. Allen Creek near Rochester. C. Black Creek at Churchville.

12. Mean monthly flows of three streams in Monroe County, N.Y., for period of record and three-year period, water years 1997-99, in relation to normal range (flows between the 25th and 75th percentile) for period of record: A. Irondequoit Creek at Blossom Road. B. Allen Creek near Rochester. C. Black Creek at Churchville.

13. Annual mean flow for Irondequoit Creek at Blossom Road and mean annual flow for period of record ....

14. Annual mean flow for Allen Creek near Rochester and Black Creek at Churchville, with mean annual flow for period of record.

15. Bar graph showing median concentrations of selected constituents at Erie (Barge) Canal diversions at Allen Creek and East Branch Allen Creek for period of record through 1999.

16. Bar graph showing median values of instantaneous flow and nutrient loads at Erie (Barge) Canal diversions at East Branch Allen Creek and Allen Creek, period of record through 1999

17. Boxplots showing ranges in concentration of selected constituents at four Irondequoit Creek basin sites, Northrup Creek and three other sites in western Monoe County, water years 1997-99.

18. Bar graph showing median concentration of selected constituents in samples from four Irondequoit Creek basin sites and Northrup Creek, for the period of record through 1996 and 1997-99

9. Plot showing concentrations of (A) total phosphorus and (B) orthophosphate along with LOWESS trendlines, before and after implementation of improved treatment for phosphorus at the Spencerport wastewatertreatment plant, at Northrup Creek, water years 1989-99.

20. Bar graph showing the annual yield of selected constituents at four sites in the Irondequoit Creek basin and four sites in western Monroe County, water years 1997-99.

\section{TABLES}

1. Monthly and annual total precipitation, with 3-year average monthly and normal monthly values, at RochesterMonroe County Airport, water years 1997-99.

2. Annual yields of selected constituents in bulk atmospheric deposition at Mendon Ponds County Park, water years 1997-99.

3. Completion data on wells in Ellison Park.

4. Descriptive statistics and trends of water levels in Ellison Park wells, period of record through 1999

5. Statistically significant differences in median concentration of chemical constituents in paired wells by depth in Ellison Park, 1997-99.

6. Statistically significant $(\alpha=0.05)$ trends in concentrations of selected ground-water constituents at Ellison Park wells, period of record through 1999.

7. Monthly maximum, minimum, and mean water temperature at four Irondequoit Creek basin sites and Northrup Creek, water years 1997-99.

8. Statistical summary and results of trend tests for streamflow at Northrup Creek and four sites in the Irondequoit Creek basin, period of record through 1999.

9. Median concentrations of selected constituents at four sites in the Irondequoit Creek basin and four sites in western Monroe County, water years 1997-99

10. Median concentrations of selected constituents at Erie (Barge) Canal diversions on East Branch Allen Creek, Allen Creek, and Irondequoit Creek, period of record through 1999

11. Median values of instantaneous flow and nutrient loads at Erie (Barge) Canal diversions on East Branch Allen Creek, and Allen Creek, period of record through 1999. 
12. Results of Tukey's Multiple Comparison Test (MCT) showing statistically significant $(\alpha=0.05)$ differences in mean concentrations of selected constituents among Irondequoit Creek basin sites and Northrup Creek, water years 1997-99.

13. Statistically significant differences between mean concentrations of selected constituents for period of record through 1996 and those for 1997-99 at Irondequoit Creek basin sites and Northrup Creek.

14. Statistical summary and results of trend tests for selected constituents at four sites in the Irondequoit Creek basin for period of record through 1999

15. Statistical summary and results of trend tests for selected chemical constituents at Northrup Creek and Genesee River for period of record through 1999

16. Equation parameter estimates showing linear dependence of concentration on flow $\left(\beta_{1}\right)$ and magnitude $\left(\beta_{3}\right)$, in percent per year, of estimated trends in loads for selected constituents, and $\mathrm{R}^{2}$ values for concentrations and loads at four sites in the Irondequoit Creek basin, Genesee River, and four sites in western Monroe County, N.Y., 1997-99.

17. Annual loads of selected constituents transported by Irondequoit Creek to Irondequoit Bay, water years 1997-99, and percentage of total annual load transported from February through May ....

18. Mean annual yields of selected constituents at four sites in the Irondequoit Creek basin, and four sites in western Monroe County, for indicated water years

19. Median concentrations of selected constituents during the non-navigation season at East Branch Allen Creek before and after construction of the detention pond at Jefferson Road.

20. Annual constituent loads with associated error and annual yield, for Genesee River at Charlotte Pump Station, water years 1997-99.

\section{APPENDIX}

Monthly loads and associated error for nine constituents at four sites in the Irondequoit Creek basin and at four sites in western Monroe County, water years 1997-99 
CONVERSION FACTORS AND VERTICAL DATUM

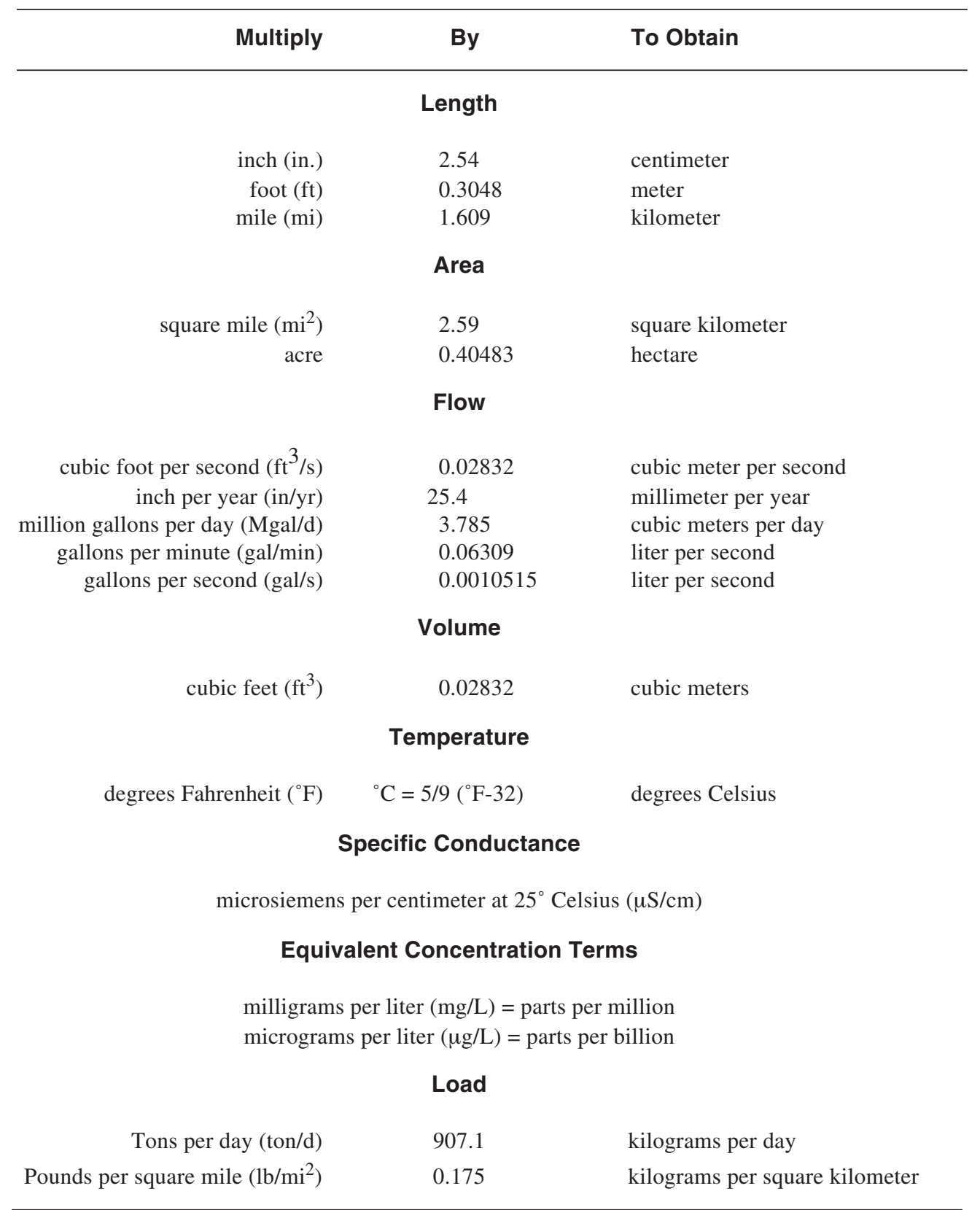

Vertical datum: In this report "sea level" refers to the National Geodetic Vertical Datum of 1929 (NGVD of 1929) — a geodetic datum derived from a general adjustment of the first-order level nets of the United States and Canada, formerly called Sea Level Datum of 1929. 


\title{
Water Resources of Monroe County, New York, Water Years 1997-99, with Emphasis on Water Quality in the Irondequoit Creek Basin Atmospheric Deposition, Ground Water, Streamflow, Trends in Water Quality, and Chemical Loads to Irondequoit Bay
}

\author{
By Donald A. Sherwood
}

\section{ABSTRACT}

Irondequoit Creek drains 169 square miles in the eastern part of Monroe County. Over time, nutrients transported by Irondequoit Creek to Irondequoit Bay on Lake Ontario have contributed to the eutrophication of the bay. Sewage-treatment-plant effluent, a major source of nutrients to the creek and its tributaries, was eliminated from the basin in 1979 by diversion to a regional wastewater-treatment facility, but sediment and contaminants from nonpoint sources continue to enter the creek and Irondequoit Bay.

This report, the fourth in a series of reports that present interpretive analyses of the hydrologic data collected in Monroe County since 1984, interprets data from four surface-watermonitoring sites in the Irondequoit Creek basin-Irondequoit Creek at Railroad Mills, East Branch Allen Creek at Pittsford, Allen Creek near Rochester, and Irondequoit Creek at Blossom Road. It also interprets data from three sites in the the Genesee River basin-Oatka Creek at Garbutt, Honeoye Creek at Honeoye Falls, and Black Creek at Churchville- as well as the Genesee River at Charlotte Pump Station, and also from a site on Northrup Creek at North Greece. The Northrup Creek site drains a 23.5square-mile basin in western Monroe County, and provides information on surface-water quality in streams west of the Genesee River and on loads of nutrients delivered to Long Pond, a small eutrophic embayment of Lake Ontario. The report also includes water-level and water-quality data from nine observation wells in Ellison Park, and atmospheric-deposition data from a collection site at Mendon Ponds County Park.

Average annual loads of some chemical constituents in atmospheric deposition for 199799 differed considerably from those for the long-term period 1984-96. Ammonia and potassium loads for 1997-99 were 144 and 118 percent greater, respectively, than for the previous period. Sodium and ammonia + organic nitrogen loads were 87 and 60 percent greater, respectively. Average annual loads of sulfate and orthophosphate for 1997-99 were 36 and 30 percent lower, respectively, than for the previous period.

Loads of all nutrients deposited on the Irondequoit basin from atmospheric sources during 1997-99 greatly exceeded those transported by Irondequoit Creek. The ammonia load deposited on the basin was 139 times the load transported at Blossom Road (the most downstream site); the ammonia + organic nitrogen load was 6.3 times greater, orthophosphate 7.5 times greater, total phosphorus 1.3 times greater and nitrite + nitrate 1.5 times greater. Average yields of dissolved chloride and dissolved sulfate from atmospheric 
sources were much smaller than those transported by streamflow at Blossom Road-chloride was about 2 percent and sulfate about 8 percent of the amount transported.

Trends in concentration of chemical constituents in surface water generally can be attributed to changes in land use, annual and seasonal variations in streamflow, and annual variations in the application of road salt to county highways and roads.

Concentrations of several constituents in streams of the Irondequoit Creek basin showed statistically significant $(\alpha=0.05)$ trends from the beginning of their period of record through 1999. The constituent with the greatest number of significant trends was ammonia + organic nitrogen, with downward trends ranging from 4.1 to 5.6 percent per year at Allen Creek, Irondequoit Creek at Blossom Road, and East Branch Allen Creek. Orthophosphate showed an upward trend of 4.1 percent per year at Irondequoit Creek at Railroad Mills (the most upstream site). Dissolved chloride showed upward trends at Railroad Mills, Allen Creek, and Blossom Road. No trends in volatile suspended solids were noted at any of the four Irondequoit basin sites.

Northrup Creek showed significant downward trends in concentrations of ammonia + organic nitrogen (3.3 percent per year), total phosphorus (3.4 percent per year), and orthophosphate (5.5 percent per year), and an upward trend for dissolved sulfate (1.8 percent per year). The Genesee River at Charlotte Pump Station showed downward trends of 6.1 percent per year for ammonia + organic nitrogen and 0.1 percent per year for chloride, and upward trends of 1.7 percent per year for total phosphorus and 6.6 percent per year for orthophosphate.

Mean annual yields (mass per unit area) of most constituents at the Irondequoit Creek basin sites were similar to those noted for the previous report period (1994-96). East Branch Allen Creek showed lower yields of all constituents during 1997-99 than previously, even though runoff during 1997-99 was greater. These lower yields are attributed to the construction of an upstream detention basin on East Branch Allen Creek in 1995.

Statistical analysis of long-term (greater than 12 years) streamflow records for unregulated streams in Monroe County indicated that annual mean flows for water years 1997-99 were in the normal range (75th to 25 th percentile), although Allen Creek continues to show a significant downward trend in mean monthly streamflow during the 1984-99 water years.

\section{INTRODUCTION}

Irondequoit Bay, near the city of Rochester, N.Y., (fig. 1) has been eutrophic (overly enriched with nutrients) for several decades, largely as a result of sewage, sediment, and nutrients that enter the bay from Irondequoit Creek. The discharge of sewage to Irondequoit Creek was eliminated in 1979, when the Monroe County wastewater-treatment facility along the shore of Lake Ontario began operation.

Since 1980, the U.S. Geological Survey (USGS) has conducted a program in cooperation with the Monroe County Health Department (MCHD) and the Monroe County Environmental Health Laboratory (MCEHL) to collect and analyze water-resources data from several sites in Monroe County, particularly the Irondequoit Creek basin (fig. 2). Data are analyzed to help identify sources of contamination, estimate the annual loads of selected constituents at various sites, and detect trends in concentration of these constituents in the county's streams and rivers. Although the discharge of sewage to Irondequoit Creek was eliminated in 1979, data collection has been continued in an effort to monitor the chemical quality of the creek and its tributaries and to assess the effectiveness of current resource-management practices. A similar monitoring effort began in 1990 on Northrup Creek at North Greece (fig. 1), the main tributary to Long Pond, a small, highly eutrophic (Makarewicz and others, 1990) embayment in western Monroe County along the southern edge of Lake Ontario.

During water years ${ }^{1} 1980-81$, the USGS National Urban Runoff Program (NURP) study of the

\footnotetext{
${ }^{1}$ Water year: the 12-month period from October 1 through September 30 of the following year. Thus, the water year ending on September 30, 1996, is the 1996 water year. All years referenced in this report are water years.
} 


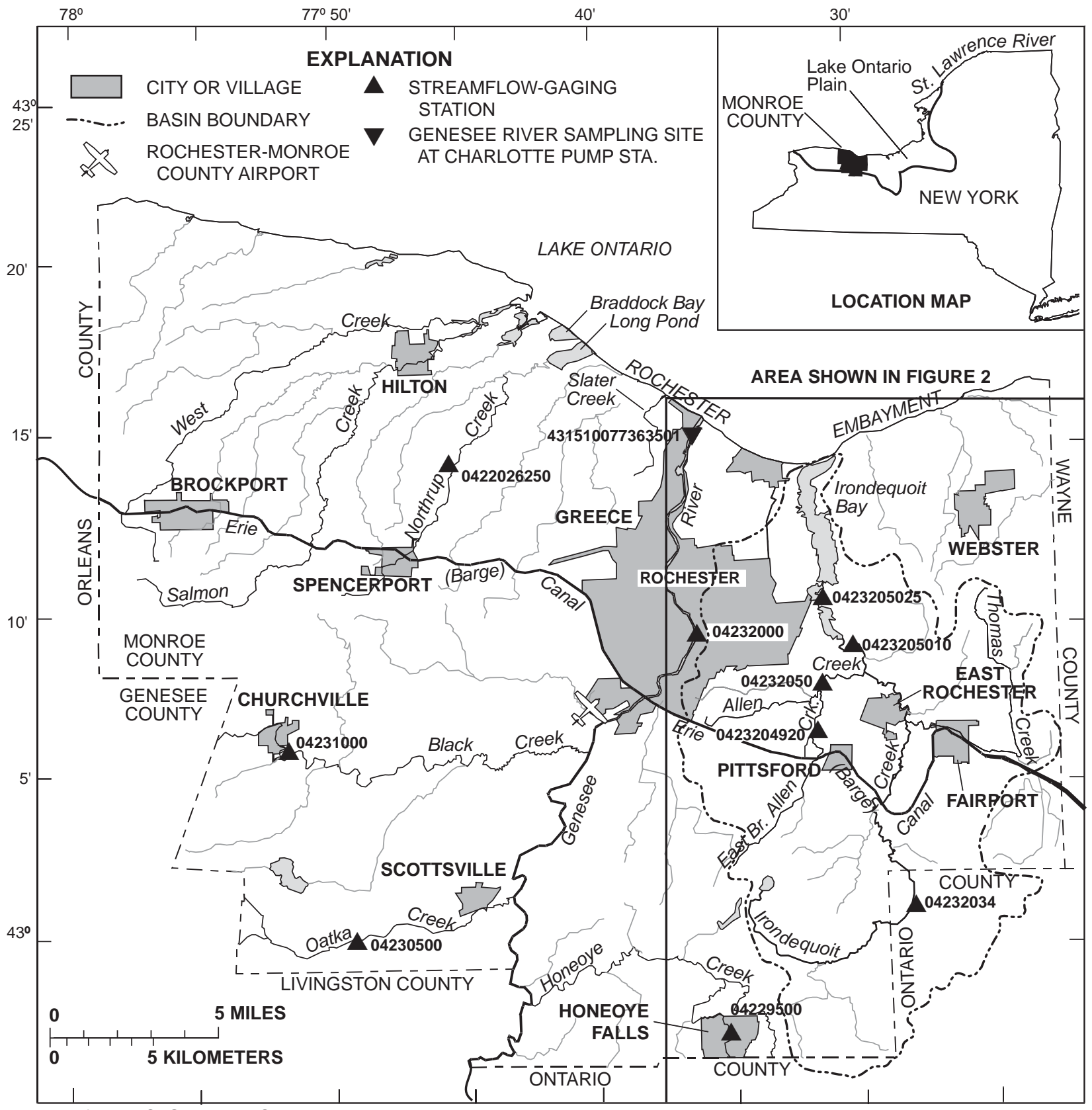

Base from U.S. Geological Survey

Digital Line Graph, 1:100,000

\section{Streamflow-gaging stations}

$\begin{array}{ll}\mathbf{0 4 2 2 0 2 6 2 5 0} & \text { Northrup Creek at North Greece } \\ \mathbf{0 4 2 2 9 5 0 0} & \text { Honeoye Creek at Honeoye Falls } \\ \mathbf{0 4 2 3 0 5 0 0} & \text { Oatka Creek at Garbutt } \\ \mathbf{0 4 2 3 1 0 0 0} & \text { Black Creek at Churchville } \\ \mathbf{0 4 2 3 2 0 0 0} & \text { Genesee River at Rochester }\end{array}$

04232034 Irondequoit Creek at Railroad Mills 0423204920 East Branch Allen Creek at Pittsford $04232050 \quad$ Allen Creek near Rochester 0423205010 Irondequoit Creek at Blossom Road 0423205025 Irondequoit Creek at Empire Boulevard

\section{Water quality site}

431510077363501 Genessee River at Charlotte Pump Station

Figure 1. Principal geographic features of Monroe County, N.Y. and locations of steamflow-gaging stations in study area (from Sherwood, 2001a, fig. 1.) 
Irondequoit Creek basin investigated nonpoint-source contamination from selected areas representing specific land uses. Results of that study provided a basis from which changes in the nutrient and chemical loads of Irondequoit Creek basin sites could be identified. In 1993, the USGS, in cooperation with the Monroe County Health Department, began a program to analyze hydrologic data collected in Monroe County to detect significant temporal trends in the concentrations of selected chemical constituents in streamflow and ground water. Statistical analysis of hydrologic data collected during water years 1984-88 are presented in Johnston and Sherwood (1996), those for water years 1989-93 are given in Sherwood (1999), and those for water years 1994-96 are given in Sherwood (2000).

\section{Purpose and Scope}

This report updates the analysis of hydrologic data presented in previous reports and describes the hydrologic conditions within Monroe County and the Irondequoit Creek basin during water years 1997-99. It describes the methods of data analysis and the statistical methods used for trend analyses and estimation of constituent loads. It provides analysis of precipitation volume and chemical quality of bulk atmospheric deposition during 1997-99, for comparison with data from the three previous periods (1984-88, 1989-93, 1994-96), analyzes fluctuations in ground-water levels in northern Ellison Park (fig. 2), and examines the vertical distribution of chemical concentrations in ground water at paired wells. It relates streamflow in Monroe County during 1997-99 to historical streamflow and to streamflow during the three previous report periods. It examines waterquality trends in Monroe County and relates chemical concentrations in 1997-99 to those of the previous three report periods and presents loads and yields of selected constituents transported by Irondequoit Creek to Irondequoit Bay and by Northrup Creek to Long Pond and by the Genesee River to Lake Ontario. Monthly and annual loads of selected constituents at the Irondequoit basin sites, Oatka Creek, Honeoye Creek, Black Creek and Northrup Creek are presented in the appendix of this report.

\section{Study area}

Monroe County encompasses $673 \mathrm{mi}^{2}$ in the Lake Ontario Plain region of western New York (fig. 1) (Heffner and Goodman, 1973). Rochester, the county seat and largest city, is in the northern part of the county. The Genesee River, which flows northward through Rochester into Lake Ontario is the largest in Monroe County and has a drainage area of 2,480 $\mathrm{mi}^{2}$ at its mouth (Wagner and Dixson, 1985). Streams in various smaller drainage basins (ranging from less than $5 \mathrm{mi}^{2}$ to about $88 \mathrm{mi}^{2}$ ) west of the Genesee River flow northeastward into Lake Ontario or to one of the many bays of the western part of the Rochester Embayment. Streams in small drainage basins (ranging from less than $0.2 \mathrm{mi}^{2}$ to nearly 24 $\mathrm{mi}^{2}$ ) east of the Genesee River flow north or northwestward into Lake Ontario and the Irondequoit Creek basin $\left(169 \mathrm{mi}^{2}\right)$.

Irondequoit Creek drains into Lake Ontario through Irondequoit Bay (fig. 2). Its drainage basin is mostly in eastern Monroe County and includes drainage from the east side of the city of Rochester and from Ontario and Wayne Counties to the south and east. Northrup Creek, drains $23.5 \mathrm{mi}^{2}$ in western Monroe County, and flows into Long Pond, a small embayment on the southern edge of Lake Ontario. A more complete description of the Irondequoit Creek basin, by Kappel and others (1986), describes stormwater and sanitary-sewer systems, drinkingwater supplies, surficial geology, and climate. The glacial history and geohydrology of the Irondequoit Creek valley are discussed in Kappel and Young (1989). Land use is discussed in Johnston and Sherwood (1996) and Sherwood (1999).

The Erie (Barge) Canal flows generally southeastward through the middle of the county and receives flow from the headwater areas the streams described above (fig. 1). Diversion structures at various points along the canal allow water from the canal to augment the flow of these small streams during low-flow conditions. The canal intersects the Genesee River 11.8 mi upstream from the river's mouth. Water diverted by the canal from Lake Erie is discharged into the Genesee River from the west; a smaller amount is then diverted from the Genesee River eastward into the canal. 


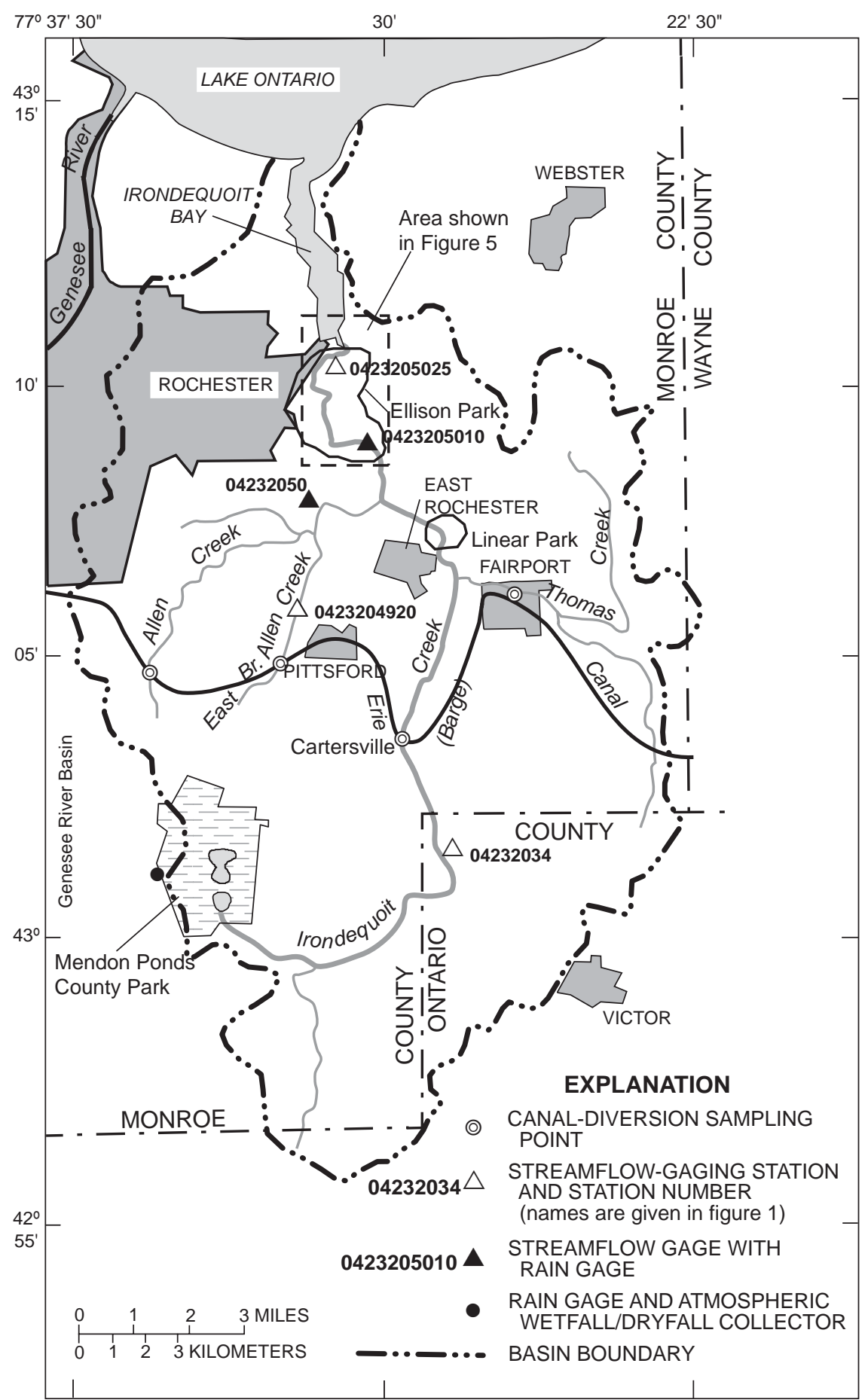

Base from U.S. Geological Survey

State base map 1:500,000, 1974

Figure 2. Locations of streamflow-gaging stations, canal-diversion sites, and atmospheric deposition collection sites within the Irondequoit Creek basin, Monroe County, N.Y. (Location is shown in fig. 1. Modified from Sherwood, 1999, fig. 2.)

\section{Acknowledgments}

Special thanks are extended to the personnel of MCEHL for assistance in the collection, analysis, and verification of the data presented herein, and in particular, to Charles Knauf and Gary Brown for their suggestions and guidance in preparing this report.

\section{ATMOSPHERIC DEPOSITION}

Records of precipitation volume collected at the Rochester-Monroe County Airport (fig. 1) and published by the National Oceanic and Atmospheric Administration (NOAA) (1983, 1997-99) were used with chemical data from Mendon Ponds County Park, near the southwestern edge of the Irondequoit basin (fig. 2), for computation of constituent loads from atmospheric deposition within the Irondequoit Creek basin. The Mendon Ponds site was selected to represent deposition that is unaffected by urban emissions. Data from Mendon Ponds County Park included wetfall (liquid deposition), dustfall (dry deposition, the fraction that settles out of the atmosphere as dust), and bulk (composite) deposition, which consists of the two previous forms. The three forms of deposition were analyzed for common ions, nutrients, and lead, and for physical characteristics such as $\mathrm{pH}$ and specific conductance. The values obtained from the bulk samples have been used throughout this series of reports because bulkdeposition samples seemed to be the form most free from occasional contamination by birds and insects and from collector malfunction, and to provide the most reliable results. Also, there was not consistent 
Table 1. Monthly and annual total precipitation, with 3-year average monthly and normal monthly values, at RochesterMonroe County Airport, N.Y., water years 1997-99.

[All values are in inches. Location is shown in fig.1.]

\begin{tabular}{|c|c|c|c|c|c|c|c|c|c|c|c|c|c|}
\hline \multirow[b]{2}{*}{ Water year } & \multicolumn{12}{|c|}{ Month } & \multirow{2}{*}{$\begin{array}{c}\text { Annual } \\
\text { total }\end{array}$} \\
\hline & Oct & Nov & Dec & Jan & Feb & Mar & Apr & May & June & July & Aug & Sept & \\
\hline 1997 & 5.40 & 4.12 & 2.97 & 2.03 & 2.40 & 3.88 & 1.33 & 2.12 & 3.01 & 1.94 & 4.22 & 5.36 & 38.78 \\
\hline 1998 & 1.94 & 3.57 & 2.88 & 5.63 & 2.34 & 3.50 & 1.81 & 2.63 & 7.11 & 6.09 & 5.39 & 3.00 & 45.89 \\
\hline 1999 & 1.54 & 1.41 & 1.60 & 3.92 & .69 & 3.29 & 2.07 & 2.72 & 2.52 & 1.78 & 5.71 & 3.41 & 30.66 \\
\hline 3-year average & 2.96 & 3.03 & 2.48 & 3.86 & 1.81 & 3.56 & 1.74 & 2.49 & 4.21 & 3.27 & 5.11 & 3.92 & 38.44 \\
\hline Normal* & 2.44 & 2.92 & 2.73 & 2.08 & 2.10 & 2.28 & 2.61 & 2.72 & 3.00 & 2.71 & 3.40 & 2.97 & 31.96 \\
\hline
\end{tabular}

*Normal values are based on the average monthly or annual totals for 1961-90.

agreement between the sum of the results of the wetfall and dryfall samples and the values obtained from the bulk samples.

The chemical composition of rainfall is highly variable, not only from place to place, but from storm to storm in a single area and within individual storm systems as well. The conditions that usually produce rain-a mingling of air masses of different properties and origins - promote a high degree of vertical and horizontal variation. Although sampling and analysis of atmospheric deposition can provide relatively accurate estimates of the amounts of each constituent that reaches the land surface, the effect of these inputs on the loads transported by streams is uncertain because of the interactions of chemicals with the land surface after their deposition until they enter the streams.

\section{Precipitation Volume}

The National Weather Service at the RochesterMonroe County Airport has collected precipitation data since May 1, 1929. Monthly total, annual total, and average monthly precipitation values for water years 1997-99 are shown in table 1; which includes "normal" values (mean values calculated from 196190 records). The 3-year average rainfall for 1997-99 was 38.44 in. (6.48 in. above normal). Several months of greater-than-normal precipitation during water year 1998 resulted in a total annual precipitation of 45.89 in. (13.93 in. above normal). Precipitation for 1997 was also above normal (6.82 in.), whereas that for 1999 was slightly (1.3 in.) below normal. Total precipitation for 1997-99 was 19.45 in. above normal.

\section{Chemical Yields}

Atmospheric deposition is a major source of nutrients, especially nitrogen, to the Irondequoit Creek basin. The yields of all nutrients from atmospheric sources for 1997-99 (table 2) were greater than the yields transported by Irondequoit Creek at its downstream end (Blossom Road) ${ }^{2}$ - ammonia by almost 14,000 percent, orthophosphate by 650 percent, ammonia + organic nitrogen by 530 percent, and total phosphorus and nitrite + nitrate by 30 percent and 50 percent, respectively. In contrast, yields of chloride and sulfate deposited on the Irondequoit Creek basin were about 2 percent and 8 percent, respectively, of those transported in streamflow at Blossom Road.

Annual yield (load per unit area) from atmospheric sources was calculated from the following formula:

$$
\text { Yield }=C P \times \text { conversion factor, }
$$

where: $C=$ concentration, in milligrams per liter; and $P=$ precipitation (annual), in inches.

The concentration $C$ is obtained from the laboratory analysis of monthly bulk samples. The conversion factor transforms the results to the desired units of yield, in mass per unit area. The yield is then multiplied by drainage area to obtain load. This computation assumes that the precipitation recorded at the rain gage fell uniformly over the entire area represented by that particular gage, which is not usually the case and, therefore, the calculated chemical load may be subject to some degree of error.

Annual yields of selected constituents from atmospheric sources to the Irondequoit Creek basin are given in table 2 . The most abundant constituent in

\footnotetext{
${ }^{2}$ Table 18 Blossom Road 1997-99 yields multiplied by $2000 \mathrm{lbs} / \mathrm{ton}$.
} 
Table 2. Annual yields of selected constituents in bulk atmospheric deposition at Mendon Ponds County Park, Monroe County, N.Y., water years 1997-99.

[Yields are in pounds per square mile. Location is shown in fig. 2.]

\begin{tabular}{|c|c|c|c|c|c|c|c|c|c|c|c|c|c|}
\hline Water year & $\begin{array}{l}\text { Calcium, } \\
\text { dis- } \\
\text { solved }\end{array}$ & $\begin{array}{l}\text { Magne- } \\
\text { sium , } \\
\text { dis- } \\
\text { solved }\end{array}$ & $\begin{array}{l}\text { Sodium, } \\
\text { dis- } \\
\text { solved }\end{array}$ & $\begin{array}{l}\text { Potas- } \\
\text { sium, } \\
\text { dis- } \\
\text { solved }\end{array}$ & $\begin{array}{c}\text { Sulfate, } \\
\text { dis- } \\
\text { solved }\end{array}$ & $\begin{array}{l}\text { Chloride, } \\
\text { dis- } \\
\text { solved }\end{array}$ & $\begin{array}{l}\text { Ammonia } \\
\text { plus } \\
\text { organic } \\
\text { nitrogen, } \\
\text { total }\end{array}$ & $\begin{array}{l}\text { Nitrite } \\
\text { plus } \\
\text { nitrate, } \\
\text { total }\end{array}$ & $\begin{array}{c}\text { Am- } \\
\text { monia } \\
\text { nitrogen, } \\
\text { dissolved }\end{array}$ & $\begin{array}{l}\text { Phos- } \\
\text { phorus, } \\
\text { total }\end{array}$ & $\begin{array}{l}\text { Ortho- } \\
\text { phos- } \\
\text { phate }\end{array}$ & $\begin{array}{l}\text { Lead, } \\
\text { total } \\
\text { recover- } \\
\text { able }\end{array}$ & $\begin{array}{l}\text { Zinc, } \\
\text { total } \\
\text { recov- } \\
\text { erable }\end{array}$ \\
\hline 1997 & 3,649 & 809 & 2,803 & 2,515 & 16,936 & 5,468 & 5,332 & 2,985 & 3,061 & 444 & 228 & 32.9 & 127 \\
\hline 1998 & 3,888 & 794 & 1,798 & 2,627 & 23,210 & 5,137 & 9,385 & 3,747 & 5,273 & 414 & 113 & 22.3 & 180 \\
\hline 1999 & 3,660 & 659 & 1,676 & 3,530 & 14,826 & 4,634 & 8,223 & 2,399 & 5,821 & 894 & 248 & 43.6 & 709 \\
\hline 1997-99 avg. & 3,732 & 754 & 2,089 & 2,891 & 18,324 & 5,080 & 7,647 & 3,043 & 4,718 & 584 & 196 & 32.9 & 339 \\
\hline 1984-96 avg. & 3,272 & 806 & 1,116 & 1,329 & 28,524 & 4,913 & 4,771 & 2,770 & 1,932 & 483 & 280 & 31.7 & 206 \\
\hline $\begin{array}{l}\text { Percent } \\
\text { difference }\end{array}$ & +14 & -6.4 & +87 & +118 & -36 & +3.4 & +60 & +9.9 & +144 & +21 & -30 & +3.8 & +65 \\
\hline
\end{tabular}

precipitation in Monroe County is dissolved sulfate. The average annual yield for water years 1997-99 was $18,300 \mathrm{lb} / \mathrm{mi}^{2}$, a 36-percent decrease over the longterm period 1984-96. Lead occurs in the smallest amounts (about $32 \mathrm{lb} / \mathrm{mi}^{2}$ ) and is little changed from the long-term average of $32.9 \mathrm{lb} / \mathrm{mi}^{2}$.

Annual yields of some constituents deposited on the Irondequoit Creek basin from atmospheric sources during 1997-99 were considerably larger than those during 1984-96 (table 2). Atmospheric yields of dissolved sodium (87 percent greater), dissolved potassium (118 percent), ammonia + organic nitrogen (60 percent), ammonia (144 percent) and total zinc (65 percent) showed considerable increases between the long-term averages (1984-96) and 1997-99 averages. The increases in these yields are due in part to the average annual precipitation for 1997-99 being 20 percent greater than normal. Yields of sulfate and orthophosphate were 36 and 30 percent lower than in 1984-96, respectively.

Annual deposition of ammonia on the Irondequoit Basin has increased steadily since 1996 (fig. 3). Reasons for this increase are difficult to assess. The increase may result from increased spring and summer application of fertilizer to agricultural areas just upwind of the Mendon Ponds deposition collector. In agricultural situations, surface volatilization (vaporization of urea to ammonia gas which is lost to the atmosphere) may occur when urea is applied to crop lands (Brown and Johnson, 1996). Surface volatilization is usually a problem in areas with high temperatures, and soils with a high $\mathrm{pH}$. One of the largest sources of ammonia in the atmosphere is fertilizers and livestock manure. Atmospheric concentrations of ammonia during 1984-99 show a clear seasonal pattern with highest concentrations during spring and summer, when fertilizer application is the heaviest (fig. 3). Long-term monthly concentrations of ammonia in bulk atmospheric deposition (fig 4.) show a gradual downward trend from 1984 through 1993 and then an upward trend from 1994 through 1999.
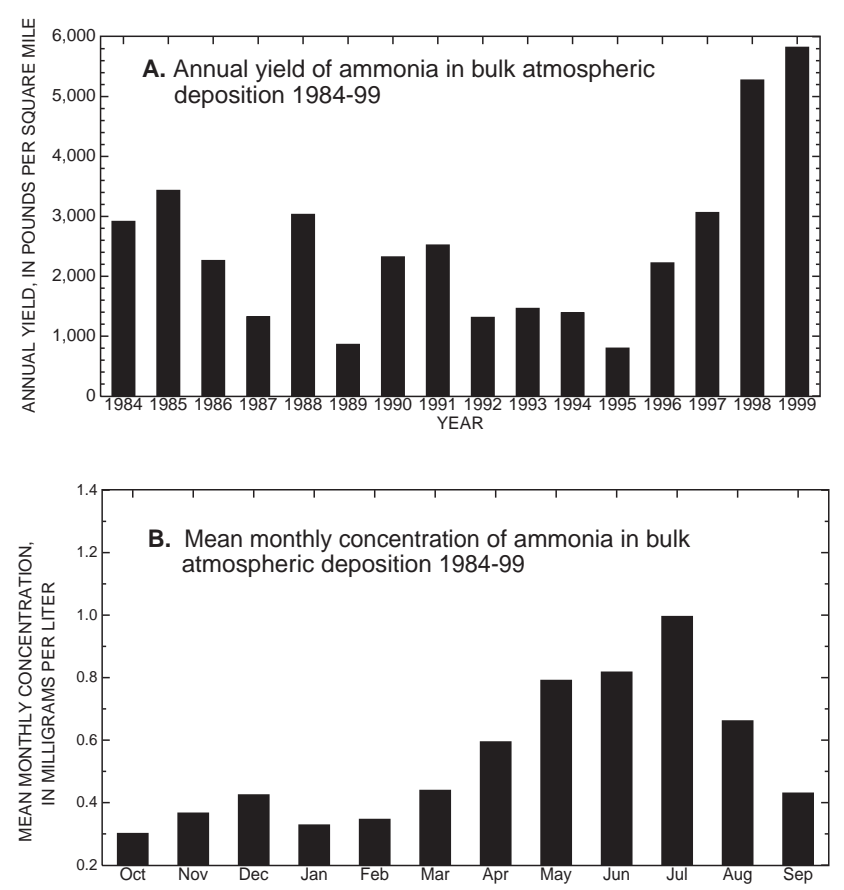

Figure 3. Ammonia in atmospheric deposition at Mendon Ponds County Park, Monroe County, N.Y. A. Annual yield of ammonia to the Irondequoit Creek basin 1984-99. B. Mean monthly concentration of ammonia in bulk atmospheric deposition. (Location is shown in fig. 2.) 


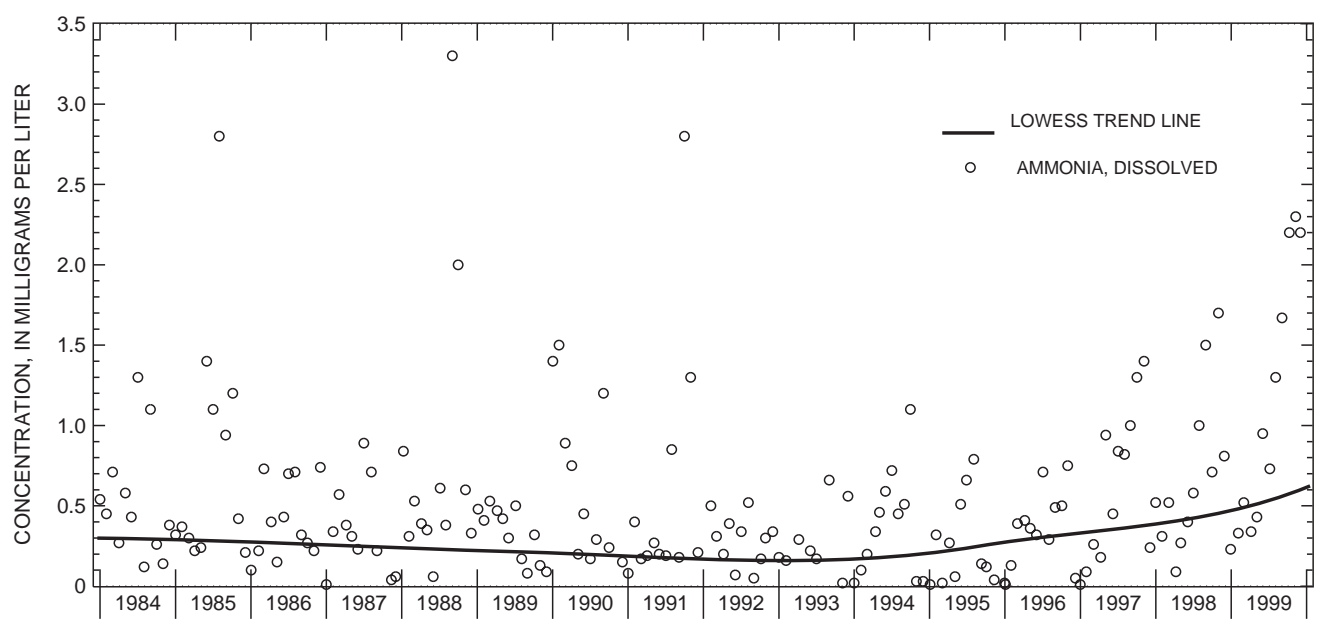

Figure 4. Monthly concentration of dissolved ammonia in bulk atmospheric deposition at Mendon Ponds County Park and locally weighted scatterplot smooth (LOWESS) trend line, Monroe County, N.Y., water years 1984-99. (LOWESS is described on page 31. Location is shown in fig. 2.)

\section{GROUND WATER}

Ground-water-level and quality data used in this report were obtained from nine observation wells in Ellison Park (fig. 5). Water levels were measured monthly and recorded to the nearest $0.01 \mathrm{ft}$. Water samples were collected twice each year during 199799 from all wells and analyzed by MCEHL for specific conductance, $\mathrm{pH}$, alkalinity, and hardness and concentrations of common ions, nutrients, metals, and dissolved solids. All wells except Mo 659 are finished in the upper (unconfined) part of the aquifer (table 3). Water levels and chemical quality at differing depths in the aquifer were compared through data from three sets of paired wells-Mo 663 and Mo 664, on the upper south slope of the buried Pinnacle Hills moraine (fig. 5), Mo 665 and Mo 666, on top of the moraine, and Mo 667 and Mo 668 on the upper north slope of the moraine.

\section{Water Levels}

Water-level data indicate frequent reversals in direction of lateral flow toward or away from the creek, as well as vertically within the aquifer.

Recharge to the sand and gravel aquifers in the glaciated northeastern United States occurs either by direct infiltration of precipitation and surface-water or by underflow from the upgradient aquifer system.

Recharge can also occur through infiltration of surface water. Recharge rates are usually highest during the
Table 3. Completion data on wells in Ellison Park, Monroe County, N.Y.

[LS, land surface; ft, feet. Locations shown in fig. 5.]

\begin{tabular}{lrccccc}
\hline $\begin{array}{c}\text { Well } \\
\text { no. }\end{array}$ & $\begin{array}{c}\text { Instal- } \\
\text { lation } \\
\text { date }\end{array}$ & $\begin{array}{c}\text { LS } \\
\text { datum } \\
\text { (ft above } \\
\text { sea level) }\end{array}$ & $\begin{array}{c}\text { Depth } \\
\text { (ft below } \\
\text { LS) }\end{array}$ & $\begin{array}{c}\text { Screen } \\
\text { interval } \\
\text { (ft below } \\
\text { LS) }\end{array}$ & $\begin{array}{c}\text { Aquifer } \\
\text { type }\end{array}$ & $\begin{array}{c}\text { Principal } \\
\text { aquifer }^{2}\end{array}$ \\
\hline \hline Mo 2 & $9 / 84$ & 252.60 & 45 & $41-45$ & $\mathrm{U}$ & $\mathrm{S} \mathrm{\&} \mathrm{G}$ \\
Mo 3 & $9 / 84$ & 253.20 & 16 & $13.5-16$ & $\mathrm{U}$ & $\mathrm{A}$ \\
Mo 659 & $12 / 86$ & 266.58 & 215 & $80-90$ & $\mathrm{C}$ & $\mathrm{S} \mathrm{\&} \mathrm{G}$ \\
& & & & $160-170$ & & \\
Mo 663 & $9 / 88$ & 251.16 & 10 & $7.5-10$ & $\mathrm{U}$ & $\mathrm{A}$ \\
Mo 664 & $9 / 88$ & 251.18 & 27 & $22-27$ & $\mathrm{U}$ & $\mathrm{A}$ \\
Mo 665 & $9 / 88$ & 254.14 & 17 & $12-17$ & $\mathrm{U}$ & $\mathrm{A}$ \\
Mo 666 & $9 / 88$ & 254.14 & 27 & $22-27$ & $\mathrm{U}$ & $\mathrm{A}$ \\
Mo 667 & $9 / 88$ & 255.38 & 15 & $10-15$ & $\mathrm{U}$ & $\mathrm{A}$ \\
Mo 668 & $9 / 88$ & 255.32 & 36 & $31-36$ & $\mathrm{U}$ & $\mathrm{A}$ \\
\hline
\end{tabular}

${ }^{1} \mathrm{U}$, unconfined; C, confined

${ }^{2}$ S \& G, sand and gravel; A, alluvium

spring snowmelt period and are lowest during midsummer, when evapotranspiration is greatest (fig. 6). Substantial recharge also can occur during fall, when evapotranspiration decreases.

All wells except Mo 2 and Mo 659 are within the flood plain of Irondequoit Creek (fig. 5) and, thus, respond to water-level fluctuations in the creek. Annual mean water levels in well Mo 3, which is on the east bank of Irondequoit Creek, averaged $2.27 \mathrm{ft}$ lower than in Mo 2, which is near the east wall of the valley and upgradient from Mo 3. Water levels in Mo 2 during 1985-99 ranged from $1.77 \mathrm{ft}$ below land 
surface to $1.25 \mathrm{ft}$ above, and those in Mo 3 ranged from $4.17 \mathrm{ft}$ below land surface to 2.03 above. Mean monthly water levels at these two wells during 1997-99 were within the monthly extremes for the period of record (fig. 7) and, except for December and March at Mo 2 and December at Mo 3, were reasonably close to the mean monthly values for the period of record. All wells, including Mo 659, which is screened in a confined aquifer, showed similar seasonal water-level fluctuations and response to recharge.

Water-level records from the beginning of the period of record through 1999 were tested for trends through the seasonal Kendall test (Hirsch and others, 1982), described further on. Two of the nine wells-Mo 659 and Mo 667 - showed statistically significant $(\alpha=$ 0.05 ) upward trends in water level for the period of record (table 4).

\section{Chemical Concentrations}

Comparison of water-quality data among wells can indicate local differences in water quality within a given aquifer, ground-water movement to or from a stream, and possible sources of contamination and the degree of mixing. Water-quality data also can be used to estimate temporal trends in ground-water chemistry at a given site. Factors that affect ground-water quality are well depth and location, rate and direction of ground-water flow (vertical and horizontal), type of aquifer material, availability of dissolved oxygen, and precipitation amount and intensity.

The Oneway Analysis of Variance (ANOVA) combined with Tukey's multiple comparison test was used to identify statistically significant areal differences in mean concentration of selected constituents among wells, as well as differences in constituent concentration with depth at the paired wells. ANOVA is a statistical test used to determine the significance of overall differences in the means of groups of data, but it does not specify which groups are different from the others. Tukey's multiple comparison test is generally used in conjunction with ANOVA to indicate which of the groups are significantly different from the others, and whether the difference is positive or negative. The tests were performed on ranked data because water quality data are usually not normally distributed.

\section{Spatial Variability}

The highest median concentrations of nutrients continue to occur in water samples from well Mo 667,

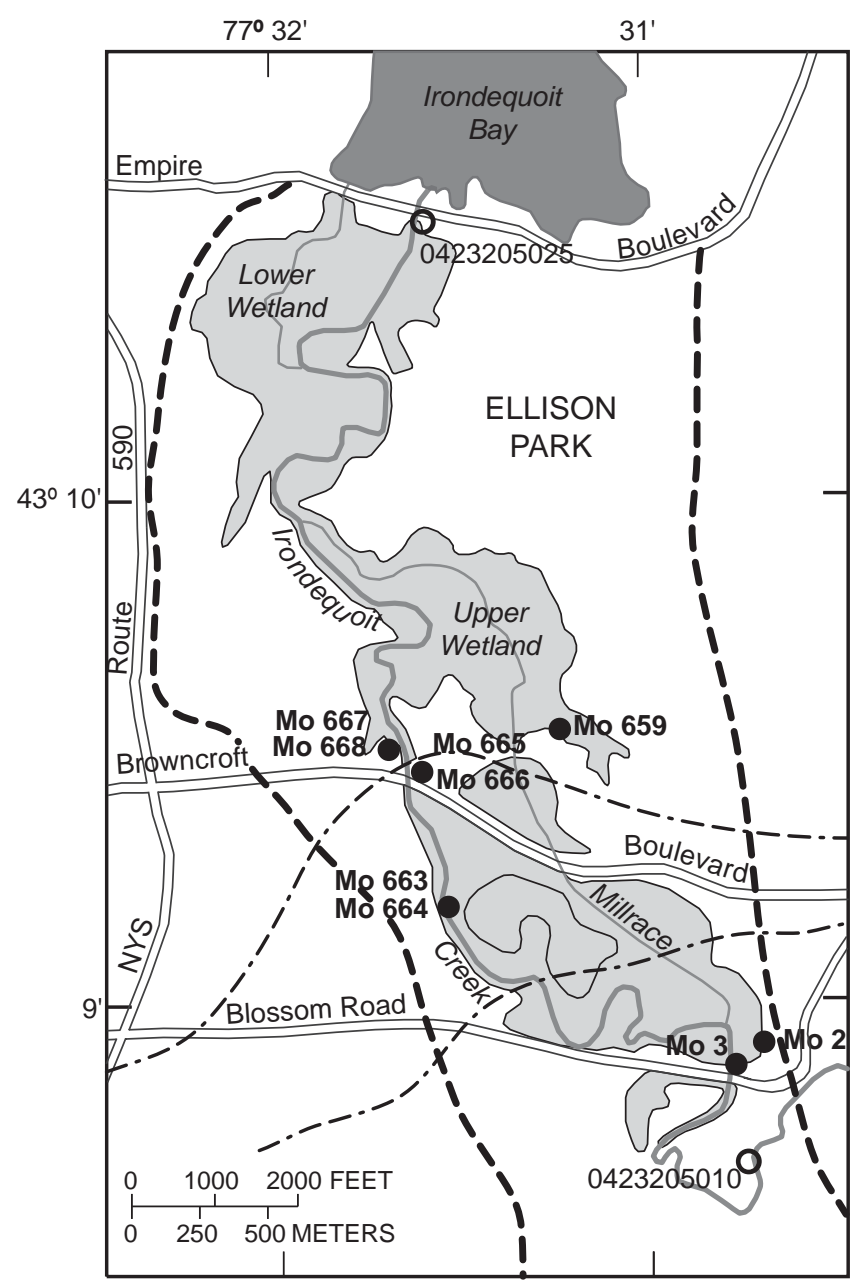

Base from scanned U.S. Geological Survey Rochester East, NY 1:24,000, 1978

\section{EXPLANATION}

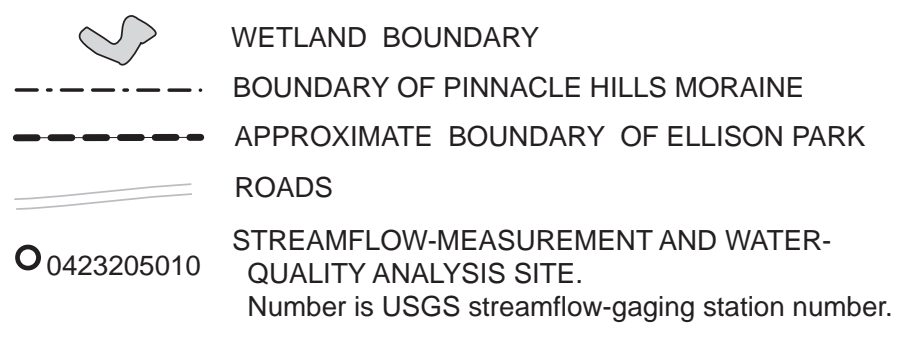

Mo 2 OBSERVATION WELL AND IDENTIFICATION NUMBER

Figure 5. Locations of observation wells in Ellison Park, Monroe County, N.Y. (Modified from Coon, 1996, fig. 2.)

the shallower (15 ft) of a well pair finished in the historic Irondequoit Creek flood-plain sediment (fig. 8). Considerable disturbance of this area occurred during the construction phase of the Pure Waters sewer project and fill and foreign material remaining on the surface may affect the water chemistry at this location (Young, 1993). High concentrations of ammonia and ammonia + 

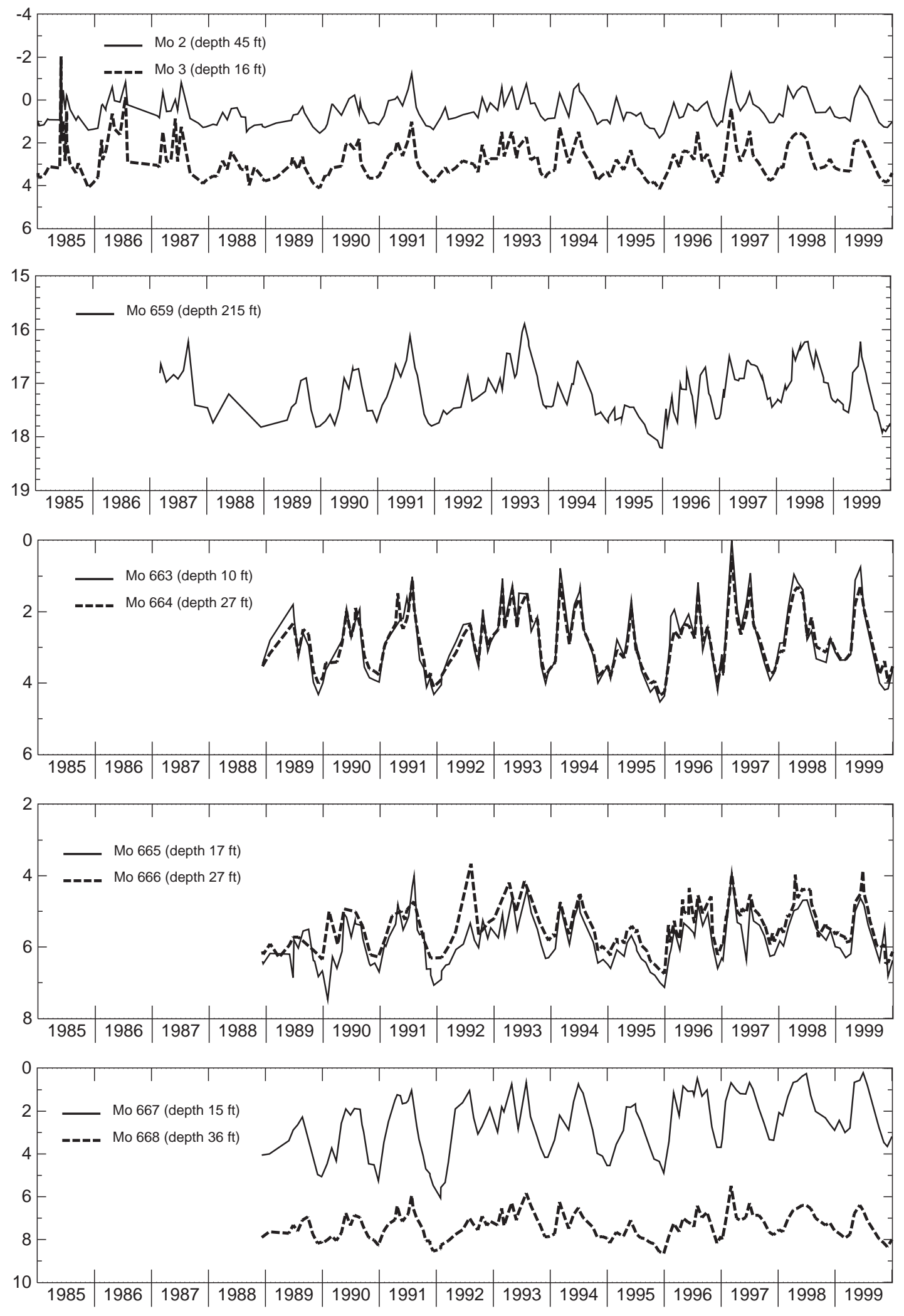

WATER YEAR

Figure 6. Water levels in Ellison Park wells, Monroe County, N.Y., water years 1985-99. (Locations are shown in fig. 5.) 


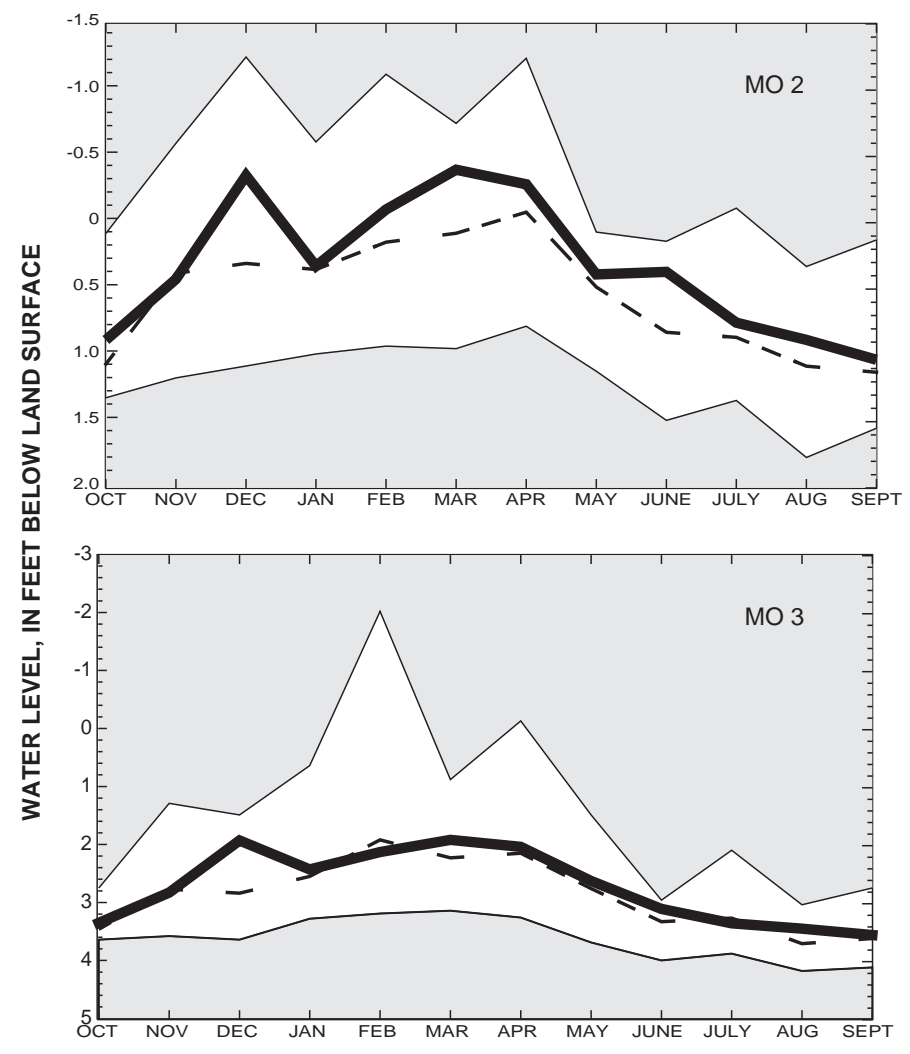

EXPLANATION

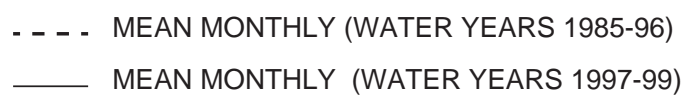

UNSHADED AREA INDICATES HIGHEST AND LOWEST MONTHLY MEAN WATER LEVEL FOR 1985-96

Figure 7. Mean monthly water levels at wells Mo 2 and Mo 3, Monroe County, N.Y., for 1997-99, with mean monthly, maximum, and minimum water levels for 1985-96. (Locations are shown in fig. 5.) organic nitrogen were also detected at wells Mo 666 and Mo 668. Mo 668 is the deeper (36 ft) of the well pair Mo 667-668, and Mo 666 is near Mo 667. Median 1997-99 concentrations of ammonia and ammonia + organic nitrogen for well Mo 666 were slightly higher than those for the previous period of record, whereas those for wells Mo 667 and Mo 668 were lower. The highest median concentrations of nitrite + nitrate $(0.64 \mathrm{mg} / \mathrm{L})$ for $1997-99$

occurred at Mo 3, which is affected by Irondequoit Creek. Median 1997-99 concentrations of nitrite + nitrate for all other wells was at or below the detection limit of $0.05 \mathrm{mg} / \mathrm{L}$. Median concentrations of total phosphorus for Mo 667 were considerably higher than those for any of the other wells, but were lower than the median for the previous period of record. The lower median concentrations for 1997-99 at Mo 667 may reflect a lessening of the effect of the disturbed area around the well.

Common ion concentrations for 1997-99 were again considerably higher at Mo 664 than at any of the other wells. Mo 664 is at the upstream edge of the buried Pinnacle Hills moraine and is subject to an upward flow from a pool of mineralized water that has collected at the base of the moraine (Young, 1993). Median concentrations of common ions for 1997-99 were lower than for the previous period of record however, except for dissolved sulfate, where the median concentration was slightly higher (about $20 \mathrm{mg} / \mathrm{L}$ ).

Median concentrations of iron at the upgradient wells (Mo 664 - Mo 668), were slightly higher for the 1997-99 period than previous period of record values at wells Mo 665 and Mo 666 and

Table 4. Descriptive statistics and trends of water levels in Ellison Park wells, Monroe County, N.Y., period of record through 1999.

[Values are in feet below land surface except as noted. $p$, significance of trend. Bold type indicates trend is statistically significant at $\alpha=0.05$. Well locations are shown in fig. 5.]

\begin{tabular}{|c|c|c|c|c|c|c|c|c|c|c|}
\hline \multirow[b]{2}{*}{ Well no. } & \multirow[b]{2}{*}{$\begin{array}{l}\text { Period of } \\
\text { Record }\end{array}$} & \multicolumn{6}{|c|}{ Descriptive statistics } & \multicolumn{3}{|c|}{ Trend } \\
\hline & & Max & Min & Mean & $\begin{array}{l}\text { 25th } \\
\text { percentile }\end{array}$ & $\begin{array}{l}\text { 50th percentile } \\
\text { (median) }\end{array}$ & $\begin{array}{c}\text { 75th } \\
\text { percentile }\end{array}$ & $\begin{array}{c}\text { Units per } \\
\text { year }\end{array}$ & $\begin{array}{l}\text { Percent } \\
\text { per year }\end{array}$ & $p$ \\
\hline Mo 2 & $1985-99$ & -1.25 & 1.77 & 0.52 & 1.00 & 0.60 & 0.12 & 0.02 & 0.52 & 0.108 \\
\hline Mo 3 & $1985-99$ & -2.03 & 4.17 & 2.79 & 3.41 & 3.00 & 2.37 & .02 & .60 & .140 \\
\hline Мo 659 & 1987-99 & 15.89 & 18.21 & 17.18 & 17.54 & 17.25 & 16.85 & .02 & .11 & .051 \\
\hline Mo 663 & 1989-99 & 0.00 & 4.53 & 2.80 & 3.56 & 2.48 & 2.14 & .02 & .62 & .561 \\
\hline Mo 664 & 1989-99 & 0.42 & 4.35 & 2.81 & 3.42 & 2.89 & 2.34 & .02 & .64 & .411 \\
\hline Mo 665 & $1989-99$ & 3.90 & 7.48 & 5.81 & 6.35 & 5.83 & 5.35 & .03 & .52 & .089 \\
\hline Mo 666 & 1989-99 & 3.66 & 6.75 & 5.42 & 5.93 & 5.46 & 5.00 & .04 & .65 & .096 \\
\hline Мo 667 & 1989-99 & 0.20 & 6.06 & 2.59 & 3.75 & 2.50 & 1.50 & .15 & 5.90 & .000 \\
\hline Mo 668 & 1989-99 & 5.49 & 8.65 & 7.38 & 7.86 & 7.38 & 6.97 & .03 & .34 & .125 \\
\hline
\end{tabular}



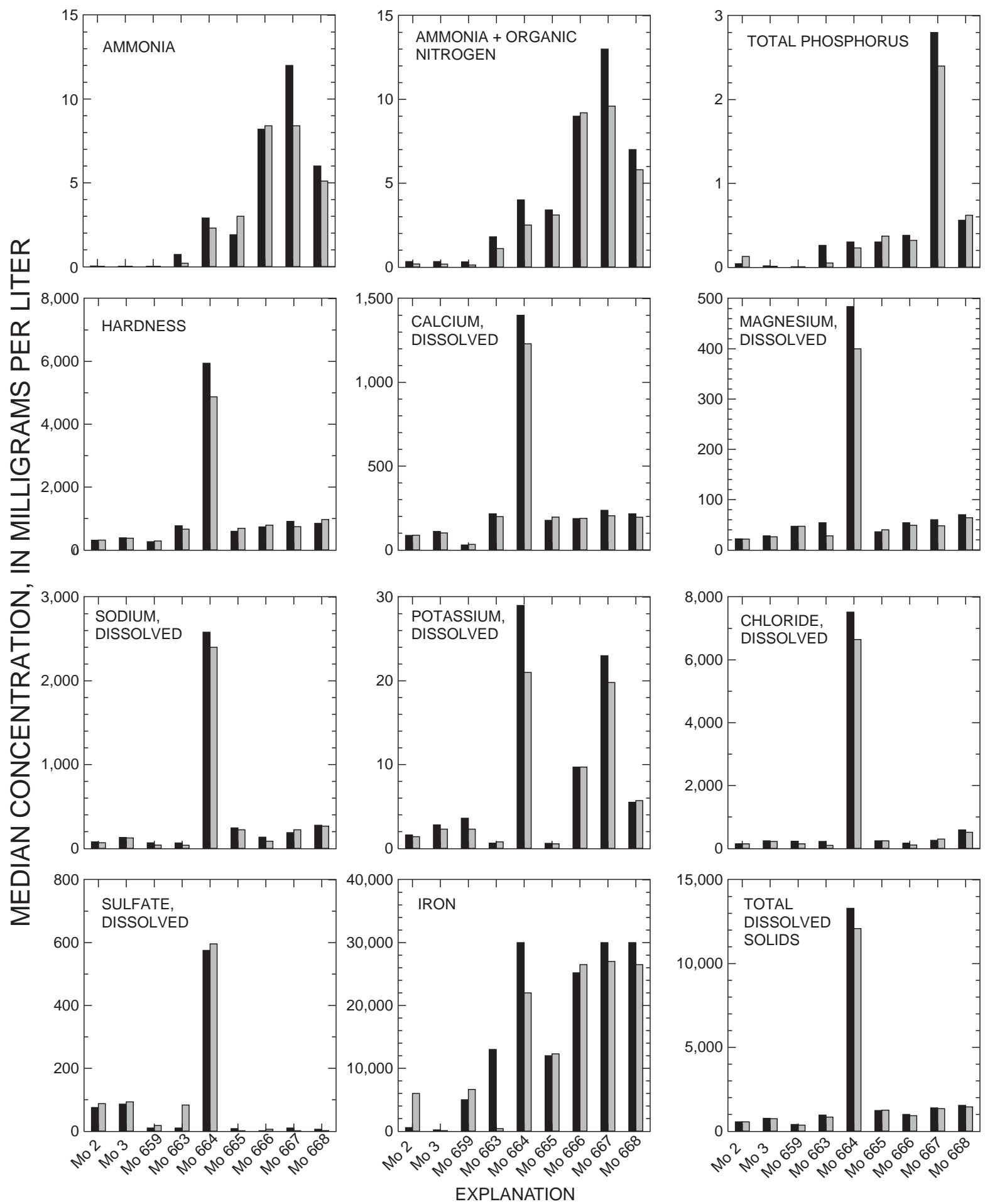

Period of record through 1996

¿ 1997-99

Figure 8. Median concentrations of selected constituents in Ellison Park wells, Monroe County, N.Y., for period of record through 1996 and for 1997-99. (Locations are shown in fig. 5.) 
slightly lower at wells Mo 664, Mo 667, and

Mo 668.

Median concentrations of most constituents in shallow wells showed significant differences from those in the deep well of a well pair. Generally, the lower concentrations were detected in the shallow wells. Well pair Mo 663-664, showed higher concentrations of all constituents at depth (well 664) except for turbidity, nitrite + nitrate, and hardness, which showed no difference in concentration with depth. The significantly higher concentrations of common ions in the deep well are attributed to the upwelling of mineralized water from the base of the Pinnacle Hills moraine. Well pair Mo 665-666 showed similar results, except that total dissolved solids showed no difference with depth. Well pair Mo 667-668 showed no significant differences with depth for nitrite + nitrate, hardness or dissolved sulfate; the other constituents were about equally divided-six showed higher median concentrations in the shallow (Mo 667) well, and five constituents showed higher concentrations in the deep (Mo 668) well (table 5).

\section{Temporal Trends}

Constituent concentrations in water samples from Ellison Park wells were tested for trends through the Kendall slope estimator, a nonparametric test that does not account for seasonality in the data. The Kendall slope estimator incorporates the Mann-Kendall test to determine the statistical significance of the trend.

A total of 75 significant trends were detected among all wells and constituents; approximately twothirds (69 percent) of these trends were downward (table 6). The well with the highest number of constituents showing a significant trend was well Mo 3, where 11 of the 17 measured constituents showed a downward trend, and one (ammonia) showed an upward trend. Wells Mo 2 and Mo 663 showed significant trends in the concentration of 10 constituents (eight downward at each well), whereas well Mo 666 showed significant trends in the concentration of only 4 constituents, 3 of which were downward. The constituent showing the greatest number of trends (8) among the wells was turbidity; the trend was upward at 4 wells and downward at 4 wells.
Table 5. Statistically significant differences in median concentration of selected chemical constituents in paired wells, by depth, in Ellison Park, Monroe County, N.Y., 1997-99. $[\mathrm{D}$, mean for deep well is significantly higher than for shallow well; $\mathrm{S}$, mean for shallow well is significantly higher than for deep well; nd, no significant difference. Locations are shown in fig. 5.]

\begin{tabular}{lccc}
\hline \multirow{2}{*}{\multicolumn{1}{c}{ Constituent or Property }} & \multicolumn{3}{c}{ Well Pair } \\
\cline { 2 - 4 } & Mo 663 & Mo 665 & Mo 667 \\
& Mo 664 & Mo 666 & Mo 668 \\
\hline Turbidity & nd & nd & S \\
Specific conductance & D & D & D \\
Ammonia, dissolved & D & D & S \\
Ammonia + organic nitrogen, total & D & D & S \\
Nitrite + Nitrate, total & nd & nd & nd \\
Phosphorus, total & D & D & S \\
Hardness & nd & nd & nd \\
Magnesium, dissolved & D & D & D \\
Sodium, dissolved & D & D & D \\
Potassium, dissolved & D & D & S \\
Chloride, dissolved & D & D & D \\
Sulfate, dissolved & D & D & nd \\
Iron, dissolved & D & D & S \\
Total dissolved solids & D & D & D \\
\hline
\end{tabular}

The only well to show no trend in turbidity was Mo 2 . The three constituents with the fewest number of trends (two each) were nitrite + nitrate, orthophosphate, and iron (dissolved oxygen was omitted because it was measured in only three wells). The common ions as a group showed the greatest number of trends among wells, most of which were downward. The constituent with the greatest number of significant trends (5) was ammonia; four of these were downward.

\section{SURFACE WATER}

Stage and streamflow data were collected at four sites in the Irondequoit Creek basin and at four sites in the Genesee River basin. Water-quality data were collected at four of the gaging stations in the Irondequoit Creek basin, at the Charlotte Pump station on the Genesee River (fig. 1) at a site on Northrup Creek in western Monroe County and at three other western Monroe County tributaries to the Genesee River-Honeoye Creek at Honeoye Falls, Oatka Creek at Garbutt, and Black Creek at Churchville. Streamflow and chemical-concentration data were used to test for trends in concentrations and to estimate annual loads of constituents transported by the streams. 
Table 6. Statistically significant $(\alpha=0.05)$ trends in concentrations of selected ground-water constituents at Ellison Park wells, Monroe County, N.Y., period of record through 1999.

[ $\downarrow$, downward trend; $\uparrow$, upward trend; $\rightarrow$, no trend. Dashes indicate insufficient data for trend test. Locations are shown in fig. 5]

\begin{tabular}{|c|c|c|c|c|c|c|c|c|c|c|c|c|}
\hline Constituent or Property & $\begin{array}{c}\text { Mo } 2 \\
(1986- \\
99) \\
\end{array}$ & $\begin{array}{c}\text { Mo } 3 \\
(1986- \\
99) \\
\end{array}$ & $\begin{array}{c}\text { Mo } 659 \\
(1991- \\
99)\end{array}$ & $\begin{array}{c}\text { Mo } 663 \\
(1991- \\
99)\end{array}$ & $\begin{array}{c}\text { Mo } 664 \\
(1991- \\
99)\end{array}$ & $\begin{array}{c}\text { Mo } 665 \\
(1991- \\
99)\end{array}$ & $\begin{array}{c}\text { Mo } 666 \\
(1993- \\
99)\end{array}$ & $\begin{array}{c}\text { Mo } 667 \\
(1991- \\
99)\end{array}$ & $\begin{array}{c}\text { Mo } 668 \\
(1991- \\
99)\end{array}$ & $\begin{array}{c}\text { Total } \\
\text { no. } \\
\text { trends }\end{array}$ & $\begin{array}{c}\text { Up- } \\
\text { ward }\end{array}$ & $\begin{array}{l}\text { Down- } \\
\text { ward }\end{array}$ \\
\hline Turbidity & $\rightarrow$ & $\downarrow$ & $\uparrow$ & $\downarrow$ & $\downarrow$ & $\uparrow$ & $\uparrow$ & $\uparrow$ & $\downarrow$ & 8 & 4 & 4 \\
\hline Specific conductance & $\downarrow$ & $\downarrow$ & $\uparrow$ & $\rightarrow$ & $\rightarrow$ & $\uparrow$ & $\downarrow$ & $\rightarrow$ & $\rightarrow$ & 5 & 2 & 3 \\
\hline Oxygen, dissolved & $\downarrow$ & $\rightarrow$ & -- & -- & $\rightarrow$ & -- & -- & -- & -- & 1 & 0 & 1 \\
\hline Ammonia, dissolved & $\downarrow$ & $\uparrow$ & $\rightarrow$ & $\downarrow$ & $\rightarrow$ & $\rightarrow$ & $\rightarrow$ & $\downarrow$ & $\downarrow$ & 5 & 1 & 4 \\
\hline Ammonia + organic nitrogen, total & $\downarrow$ & $\downarrow$ & $\rightarrow$ & $\downarrow$ & $\downarrow$ & $\rightarrow$ & $\rightarrow$ & $\rightarrow$ & $\rightarrow$ & 4 & 0 & 4 \\
\hline Nitrite + nitrate, total & $\uparrow$ & $\rightarrow$ & $\rightarrow$ & $\uparrow$ & $\rightarrow$ & $\rightarrow$ & $\rightarrow$ & $\rightarrow$ & $\rightarrow$ & 2 & 2 & 0 \\
\hline Phosphorus, total & $\rightarrow$ & $\downarrow$ & $\rightarrow$ & $\downarrow$ & $\rightarrow$ & $\uparrow$ & $\rightarrow$ & $\uparrow$ & $\rightarrow$ & 4 & 2 & 2 \\
\hline Orthophosphate, dissolved & $\rightarrow$ & $\rightarrow$ & $\uparrow$ & $\uparrow$ & $\rightarrow$ & $\rightarrow$ & $\rightarrow$ & $\rightarrow$ & $\rightarrow$ & 2 & 2 & 0 \\
\hline Hardness & $\rightarrow$ & $\downarrow$ & $\uparrow$ & $\downarrow$ & $\rightarrow$ & $\uparrow$ & $\rightarrow$ & $\rightarrow$ & $\rightarrow$ & 4 & 2 & 2 \\
\hline Calcium, dissolved & $\rightarrow$ & $\downarrow$ & $\uparrow$ & $\rightarrow$ & $\rightarrow$ & $\uparrow$ & $\rightarrow$ & $\downarrow$ & $\downarrow$ & 5 & 2 & 3 \\
\hline Magnesium, dissolved & $\rightarrow$ & $\downarrow$ & $\uparrow$ & $\downarrow$ & $\rightarrow$ & $\uparrow$ & $\downarrow$ & $\downarrow$ & $\downarrow$ & 7 & 2 & 5 \\
\hline Sodium, dissolved & $\downarrow$ & $\rightarrow$ & $\rightarrow$ & $\downarrow$ & $\rightarrow$ & $\downarrow$ & $\downarrow$ & $\uparrow$ & $\downarrow$ & 6 & 1 & 5 \\
\hline Potassium, dissolved & $\downarrow$ & $\downarrow$ & $\downarrow$ & $\rightarrow$ & $\downarrow$ & $\downarrow$ & $\rightarrow$ & $\downarrow$ & $\rightarrow$ & 6 & 0 & 6 \\
\hline Chloride, dissolved & $\downarrow$ & $\downarrow$ & $\rightarrow$ & $\downarrow$ & $\downarrow$ & $\rightarrow$ & $\rightarrow$ & $\rightarrow$ & $\downarrow$ & 5 & 0 & 5 \\
\hline Sulfate, dissolved & $\uparrow$ & $\rightarrow$ & $\rightarrow$ & $\rightarrow$ & $\uparrow$ & $\downarrow$ & $\rightarrow$ & $\downarrow$ & $\downarrow$ & 5 & 2 & 3 \\
\hline Iron, dissolved & $\rightarrow$ & $\downarrow$ & $\rightarrow$ & $\rightarrow$ & $\downarrow$ & $\rightarrow$ & $\rightarrow$ & $\rightarrow$ & $\rightarrow$ & 2 & 0 & 2 \\
\hline Total dissolved solids & $\downarrow$ & $\downarrow$ & $\uparrow$ & $\rightarrow$ & $\rightarrow$ & $\rightarrow$ & $\rightarrow$ & $\rightarrow$ & $\downarrow$ & 4 & 1 & 3 \\
\hline Total number of trends & 10 & 12 & 8 & 10 & 6 & 9 & 4 & 8 & 8 & 75 & & \\
\hline Upward trends & 2 & 1 & 7 & 2 & 1 & 6 & 1 & 3 & 0 & & 23 & \\
\hline Downward trends & 8 & 11 & 1 & 8 & 5 & 3 & 3 & 5 & 8 & & & 52 \\
\hline
\end{tabular}

\section{Water Temperature}

Temperature is one of the most important factors in water-quality control because it affects most physical properties of water as well as the rate of chemical reactions and the activity of all organisms in the aquatic environment. Some of the physical properties that are affected by temperature are density, specific heat, rate of vaporization, viscosity, and gas diffusibility; these properties in turn affect stratification, evaporation, velocity of settling particles, and dissolved oxygen saturation. Water temperature also affects the ionic strength and electrical conductivity of water, the solubility of constituents, and the growth and death rates of microorganisms, which are important to the biological processes of waste decomposition. Temperature changes also can affect higher aquatic organisms such as fish, although the effects are more complex and differ among species.

Monroe County began collecting continuous records of water temperature at the four Irondequoit Creek basin surface-water-monitoring sites and at
Northrup Creek in 1994. Temperatures reported herein (table 7) were recorded at a single point in the stream cross section and stream reach and, therefore, may not be representative of temperatures upstream or downstream of the monitoring site. Several factors affect the temperature of stream water as it moves down the channel; these include ground-water contribution, precipitation, the amount of solar radiation reaching the stream, and tributaries entering the stream.

In recent years, the New York State Department of Environmental Conservation (NYSDEC) has expressed concern as to whether discharges from stormflow-detention facilities to receiving streams may cause temperature increases that are detrimental to trout. Typically the temperature of water detained by a stormflow-detention basin increases during the summer through solar warming, and is often warmer than the water in receiving streams because it has previously been in contact with hot impervious surfaces. The NYSDEC threshold for discharges to trout streams are, that no discharge to trout streams will exceed $70^{\circ} \mathrm{F}\left(21.1^{\circ} \mathrm{C}\right)$, and no discharge from 
Table 7. Monthly maximum, minimum, and mean water temperatures at four sites in the Irondequoit Creek basin sites and Northrup Creek, Monroe County, N.Y., water years 1997-99.

[All values are in degrees Celsius; dashes indicate no data. Locations are shown in fig. 1.]

\begin{tabular}{|c|c|c|c|c|c|c|c|c|c|c|c|c|c|c|c|}
\hline \multirow[b]{2}{*}{ Month } & \multicolumn{3}{|c|}{$\begin{array}{l}\text { Irondequoit Creek } \\
\text { at Blossom Road }\end{array}$} & \multicolumn{3}{|c|}{$\begin{array}{c}\text { Allen Creek } \\
\text { near Rochester }\end{array}$} & \multicolumn{3}{|c|}{$\begin{array}{l}\text { East Branch } \\
\text { Allen Creek } \\
\text { at Pittsford }\end{array}$} & \multicolumn{3}{|c|}{$\begin{array}{l}\text { Irondequoit Creek } \\
\text { at Railroad Mills }\end{array}$} & \multicolumn{3}{|c|}{$\begin{array}{l}\text { Northrup Creek } \\
\text { at North Greece }\end{array}$} \\
\hline & Max & Min & Mean & Max & Min & Mean & Max & Min & Mean & Max & Min & Mean & Max & Min & Mean \\
\hline \multicolumn{16}{|c|}{1997 Water Year } \\
\hline Oct 96 & 16.5 & 8.0 & 11.5 & 17.0 & 8.5 & 12.0 & 18.0 & 7.5 & 12.0 & 15.0 & 7.5 & 10.5 & 17.5 & 7.0 & 12.0 \\
\hline Nov 96 & 12.0 & 2.0 & 6.0 & 13.0 & 2.0 & 6.5 & 14.0 & 1.0 & 5.5 & 11.5 & .5 & 5.0 & 12.0 & .0 & 4.5 \\
\hline Dec 96 & 6.5 & 1.0 & 4.0 & 7.5 & 1.0 & 4.5 & 6.5 & .5 & 3.5 & 6.0 & 1.0 & 4.0 & 6.0 & .0 & 3.0 \\
\hline Jan 97 & 6.5 & .0 & 1.5 & 6.5 & .0 & 1.7 & 7.0 & .0 & 1.5 & 7.0 & .5 & 2.0 & 7.0 & .0 & .5 \\
\hline Feb 97 & 7.5 & .0 & 2.5 & 8.5 & .0 & 2.5 & 8.0 & .0 & 1.5 & 8.0 & .5 & 3.0 & 7.5 & .0 & 1.0 \\
\hline Mar 97 & 10.5 & .0 & 3.5 & 10.0 & .0 & 4.0 & 9.5 & .0 & 3.5 & 10.5 & .5 & 4.0 & 11.0 & .0 & 3.0 \\
\hline Apr 97 & 16.5 & 3.0 & 9.0 & 16.5 & 3.0 & 8.5 & 16.5 & 8.0 & 12.0 & 15.5 & 2.0 & 8.5 & 18.0 & 1.5 & 8.5 \\
\hline May 97 & 17.0 & 8.5 & 12.5 & 17.0 & 7.5 & 11.5 & 17.5 & 3.5 & 8.5 & 15.4 & 7.5 & 11.5 & 17.0 & 7.5 & 12.5 \\
\hline Jun 97 & 23.5 & 14.5 & 19.0 & 23.0 & 13.5 & 17.5 & 25.5 & 14.0 & 19.5 & 21.5 & 13.0 & 17.0 & 24.5 & 14.5 & 20.0 \\
\hline Jul 97 & 25.0 & 15.0 & 19.5 & 24.5 & 14.5 & 22.0 & 27.5 & 17.0 & 21.5 & 21.5 & 14.0 & 17.5 & 25.5 & 16.5 & 20.5 \\
\hline Aug 97 & 22.0 & 15.0 & 18.5 & 22.0 & 15.0 & 18.5 & 24.0 & 17.5 & 20.5 & 19.5 & 13.5 & 16.5 & 23.5 & 17.0 & 20.0 \\
\hline Sept 97 & 20.0 & 10.5 & 15.5 & 21.0 & 10.5 & 16.0 & 22.0 & 10.5 & 17.0 & 17.5 & 9.5 & 14.0 & 21.0 & 11.0 & 16.5 \\
\hline \multicolumn{16}{|c|}{1998 Water Year } \\
\hline Oct 97 & 17.5 & 6.5 & 11.0 & --- & --- & --- & 18.5 & 6.0 & 11.0 & 16.0 & 6.5 & 10.5 & 18.5 & 5.5 & 11.0 \\
\hline Nov 97 & 11.0 & 1.5 & 5.5 & --- & --- & --- & 12.0 & 2.0 & 6.0 & 10.5 & 2.0 & 5.5 & 10.5 & 1.0 & 5.0 \\
\hline Dec 97 & 5.0 & .5 & 3.0 & --- & --- & --- & 4.5 & .5 & 3.0 & 5.0 & .5 & 3.0 & 4.0 & .0 & 2.0 \\
\hline Jan 98 & 8.0 & .5 & 3.0 & 7.5 & 2.0 & 3.0 & 7.0 & .5 & 2.4 & 8.0 & .5 & 2.5 & 8.0 & .0 & 2.0 \\
\hline Feb 98 & 6.0 & .0 & 2.9 & 5.5 & 2.0 & 3.0 & 6.0 & .5 & 2.5 & 6.0 & .5 & 2.5 & 5.5 & .0 & 2.0 \\
\hline Mar 98 & 16.5 & .5 & 5.5 & 13.5 & 2.0 & 5.0 & 16.0 & .5 & 4.5 & 16.5 & 1.0 & 5.5 & 17.5 & .0 & 4.5 \\
\hline Apr 98 & 16.0 & 6.0 & 10.5 & 14.0 & 5.5 & 10.0 & 17.5 & 5.5 & 10.5 & 16.0 & 6.0 & 11.0 & 16.0 & 5.0 & 10.5 \\
\hline May 98 & 21.0 & 13.0 & 16.5 & --- & --- & --- & 22.5 & 12.0 & 16.5 & 20.0 & 12.0 & 16.0 & 21.5 & 12.5 & 16.5 \\
\hline Jun 98 & 24.0 & 12.5 & 18.0 & --- & --- & --- & 25.0 & 13.5 & 19.5 & 22.0 & 11.5 & 16.0 & 25.0 & 12.0 & 19.0 \\
\hline Jul 98 & 23.5 & 17.5 & 20.5 & 21.0 & 16.0 & 19.5 & 24.5 & 18.0 & 21.0 & 20.5 & 15.0 & 17.5 & 25.5 & 19.0 & 21.5 \\
\hline Aug 98 & 23.5 & 16.5 & 20.0 & 20.0 & 18.0 & 19.0 & 25.5 & 16.5 & 21.5 & 19.0 & 14.0 & 17.0 & 25.0 & 17.5 & 22.0 \\
\hline Sept 98 & 21.0 & 13.0 & 17.5 & 18.0 & 15.5 & 16.5 & 25.0 & 14.5 & 19.0 & 17.0 & 11.0 & 14.5 & 22.5 & 14.0 & 19.0 \\
\hline \multicolumn{16}{|c|}{1999 Water Year } \\
\hline Oct 98 & 16.0 & 7.0 & 12.0 & --- & --- & --- & 17.5 & 7.0 & 12.5 & 14.0 & 6.5 & 10.5 & 17.5 & 7.0 & 12.5 \\
\hline Nov 98 & 11.0 & 6.0 & 7.5 & --- & --- & --- & 11.0 & 4.0 & 7.0 & 10.5 & 5.0 & 6.5 & 11.0 & 3.0 & 6.5 \\
\hline Dec 98 & 11.5 & .0 & 4.5 & --- & --- & --- & 12.0 & .0 & 4.0 & 11.0 & .0 & 4.0 & 12.5 & .0 & 3.5 \\
\hline Jan 99 & 1.5 & .0 & .5 & --- & --- & --- & 3.0 & .0 & .5 & 2.0 & .0 & .0 & 1.0 & .0 & .0 \\
\hline Feb 99 & 4.5 & .0 & 2.0 & 5.5 & .0 & 2.5 & 5.0 & .0 & 1.5 & 4.0 & .0 & 2.0 & 5.0 & .0 & 1.0 \\
\hline Mar 99 & 11.5 & .0 & 3.5 & 11.0 & .0 & 3.0 & 11.0 & .0 & 3.0 & 10.5 & .0 & 2.5 & 12.0 & .0 & 2.0 \\
\hline Apr 99 & 16.0 & 5.5 & 10.0 & 15.5 & 5.0 & 9.5 & 17.5 & 5.0 & 10.5 & 15.0 & 5.0 & 9.0 & 16.5 & 3.5 & 9.0 \\
\hline May 99 & 21.0 & 11.5 & 16.5 & 20.5 & 10.5 & 15.0 & 22.0 & 10.5 & 16.5 & 19.0 & 9.5 & 14.5 & 22.0 & 10.5 & 16.5 \\
\hline Jun 99 & 24.5 & 14.5 & 20.0 & 24.0 & 13.5 & 18.5 & 25.5 & 16.0 & 21.0 & 21.0 & 12.0 & 16.5 & 25.5 & 15.5 & 21.0 \\
\hline Jul 99 & 27.0 & 18.0 & 22.5 & 26.5 & 17.0 & 21.5 & 27.5 & 19.5 & 23.5 & 22.5 & 14.0 & 18.0 & 28.0 & 19.0 & 23.5 \\
\hline Aug 99 & 25.0 & 16.0 & 20.0 & 24.0 & 15.0 & 19.5 & 25.5 & 17.5 & 21.0 & 20.5 & 13.0 & 16.5 & 25.0 & 17.0 & 21.0 \\
\hline Sept 99 & --- & --- & --- & 23.0 & 12.0 & 17.5 & 24.0 & 12.0 & 18.5 & 18.0 & 10.5 & 14.5 & 24.5 & 13.5 & 19.0 \\
\hline
\end{tabular}


June through September will increase stream temperature more than $2^{\circ} \mathrm{F}\left(1.1^{\circ} \mathrm{C}\right)$ over its predischarge temperature.

The optimum temperature range for trout $\left(10^{\circ}\right.$ to $22^{\circ} \mathrm{C}$ ) (Bidgood and Berst, 1969) is the range over which feeding occurs and that produces no external signs of abnormal behavior. The optimum temperature range for most species generally overlaps the upper and lower critical ranges. The critical temperature ranges $\left(19^{\circ}\right.$ to $30^{\circ}$ and $0^{\circ}$ to $\left.10^{\circ} \mathrm{C}\right)$ are the ranges over which a noticeable disturbance in the normal behavior of a fish may occur. These critical temperature ranges vary, depending on the species of fish.

Maximum daily water temperatures during 199799 exceeded the $22.0^{\circ} \mathrm{C}$ limit on many days during the summer months at all sites (table 7, fig. 9). Daily mean temperatures for those days generally were lower than 22. $0^{\circ} \mathrm{C}$, however, and those at Railroad Mills did not exceed that limit (fig. 10). The minimum daily temperatures did not exceeded $22^{\circ} \mathrm{C}$ at any of the sites.

\section{Temporal Trends in Streamflow}

Variability in streamflow reflects climatic conditions and affects many water-quality properties; it also can produce a significant bias in the trends of constituent concentrations. Concentration-todischarge relations and trends in streamflow form an important basis for interpretation of trends in water quality. For example, increasing runoff (overland flow from rainfall) causes washoff of chemical constituents to streams and thereby increases the concentrations of suspended constituents from nonpoint sources; at the same time it can decrease the concentration of some dissolved constituents through dilution. Therefore, any observed trend in constituent concentration could be at least partly due to a concurrent trend in streamflow.

Monthly mean streamflow data from the four Irondequoit Creek basin sites and Northrup Creek (table 8) were tested for trends with the Seasonal Kendall Trend Test. Trends in streamflow were considered statistically significant if the level of significance ( $p$ value) was less than or equal to 0.05 . Only those periods of streamflow with accompanying water-quality data were tested for trends.

Two sites showed significant trends in streamflow (table 8). Allen Creek in the Irondequoit Creek basin had a downward trend of 1.25 percent per year in monthly mean streamflow for 1984-99, which is consistent with the downward trend of 2.26 percent per year noted for the previous report period, 1984-96. Northrup Creek in western Monroe County showed an upward trend of 4.28 percent per year for 1989-99, which contrasts with the lack of a discernible trend for the previous report period, 1989-96. The upward trend for this period is likely the result of increased runoff from precipitation during 1997-99 and increased diversion from the Erie (Barge) canal during the navigation season. Trends observed in the four Irondequoit Creek sites and Northrup Creek are summarized in the following paragraphs.

\section{Irondequoit Creek at Blossom Road}

The Irondequoit Creek basin has two sites with at least 19 years of continuous streamflow record-Irondequoit Creek at Blossom Road (198199, 19 years), and Allen Creek near Rochester (196099, 40 years). The Blossom Road record for the $1997-$ 99 water years, showed 2 months (January and July) in which the 3-year mean monthly flows were above normal (fig. 12). The normal range is defined as between the 25 th percentile (flows exceeded 75 percent of the time) and the 75th percentile (flows exceeded 25 percent of the time). The high January mean was the result of a rainfall/snowmelt event on January 8,1998 , that produced the peak of record at this site $\left(3,300 \mathrm{ft}^{3} / \mathrm{s}\right)$. None of the 3 -year mean monthly flows for 1997-99 were below normal. Monthly mean flow for water year 1997 exceeded normal for October, November, and December and, in addition, exceeded the period-of-record median (50th percentile) for March and September (fig. 11). Flows were slightly below normal for July and August and also below the median for April. Flows for water year 1998 were above normal for January, February, March, and July, and slightly above normal for August. Flows for the remaining months were within the normal range except for April and May, when they were slightly below normal. Flows for water year 1999 were slightly above normal for March and below normal for November, December, June, and July. Annual mean flows for the period of record are shown in figure 13.

\section{Allen Creek Near Rochester}

The Allen Creek drainage basin is primarily moderate- to high-density residential land with some commercial areas and, therefore, is not representative of the rest of the Irondequoit Creek basin. Mean 

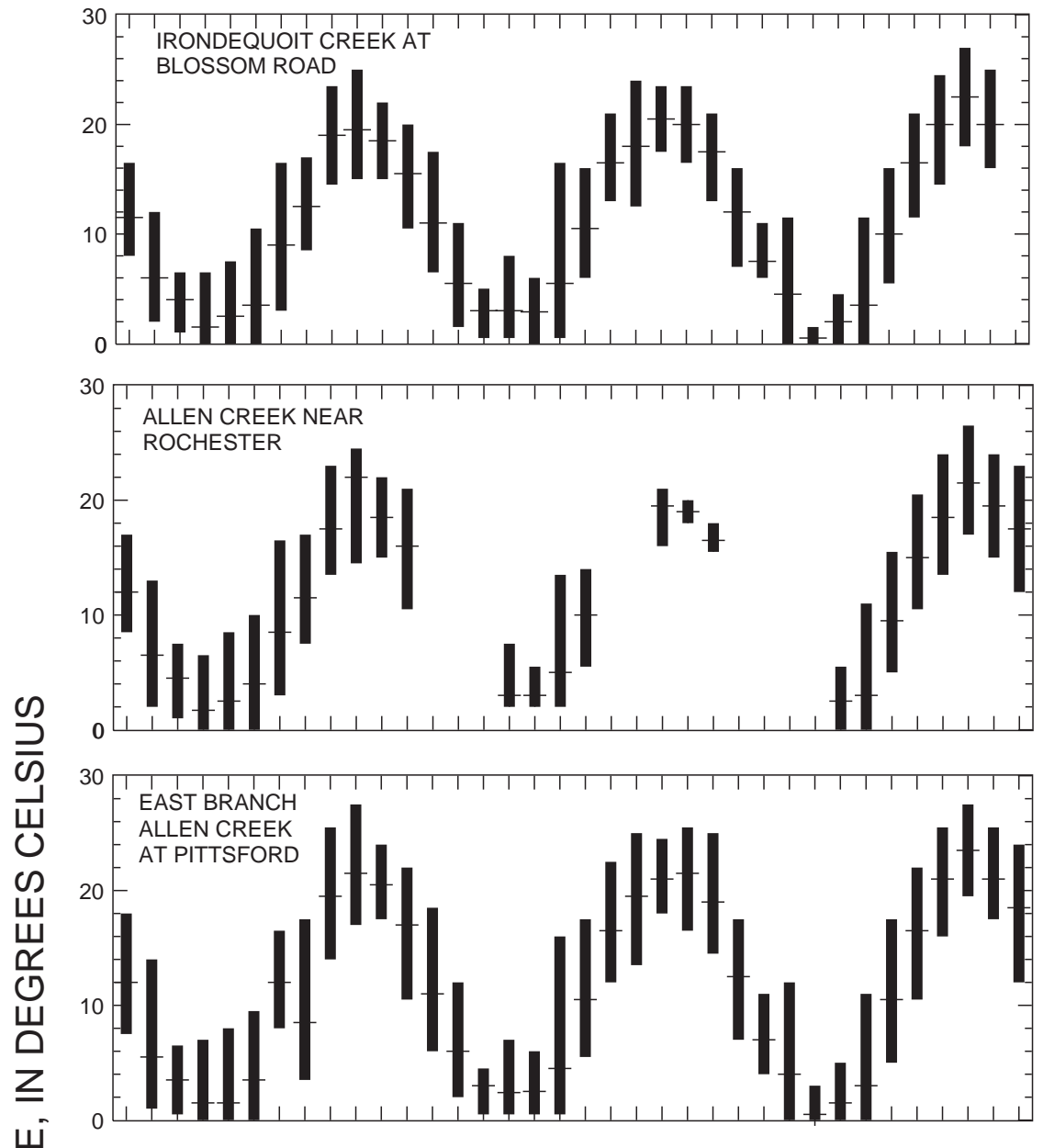

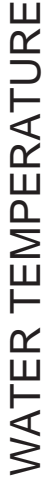
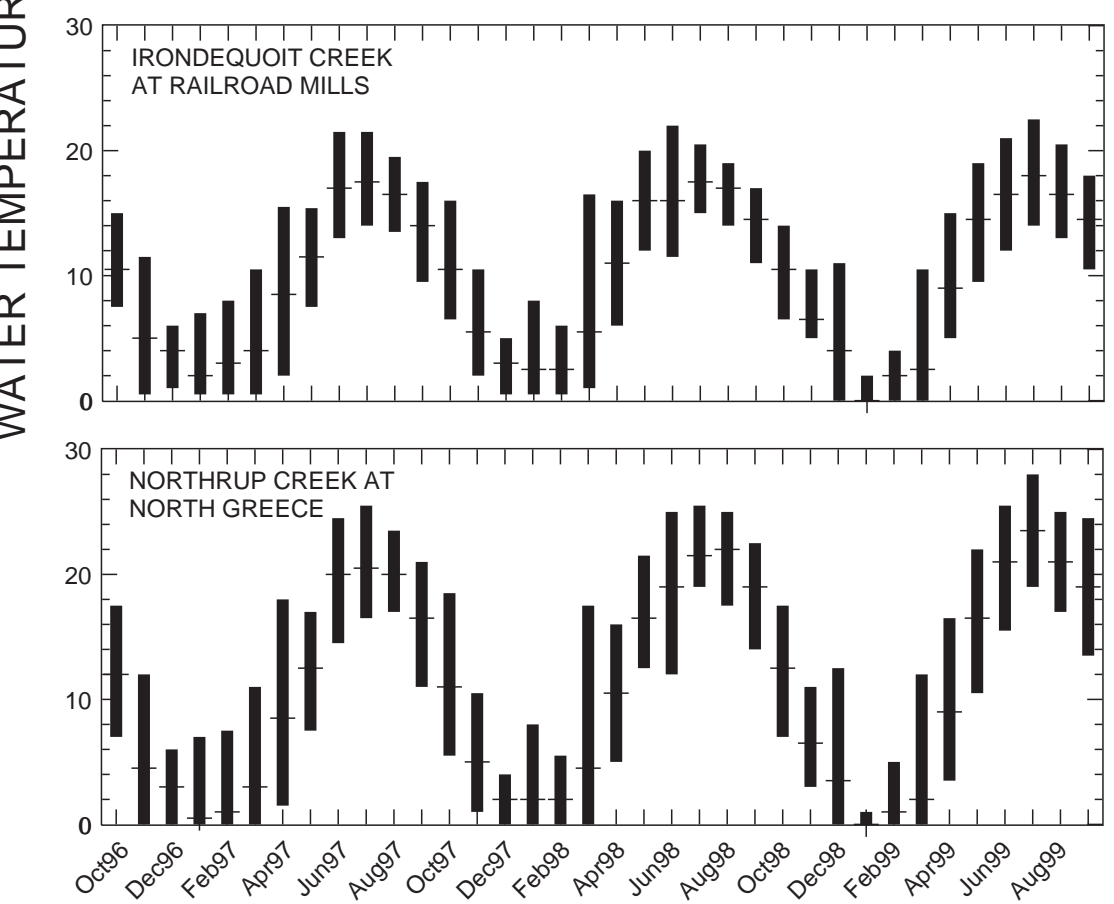

EXPLANATION

- MONTHLY TEMPERATURE RANGE

- MEAN MONTHLY TEMPERATURE
Figure 9. Monthly water-

temperature range and mean

monthly water temperature at four sites in the Irondequoit Creek basin and Northrup Creek, Monroe County, N.Y., water years 1997-99. (Locations are shown in fig. 1.) 


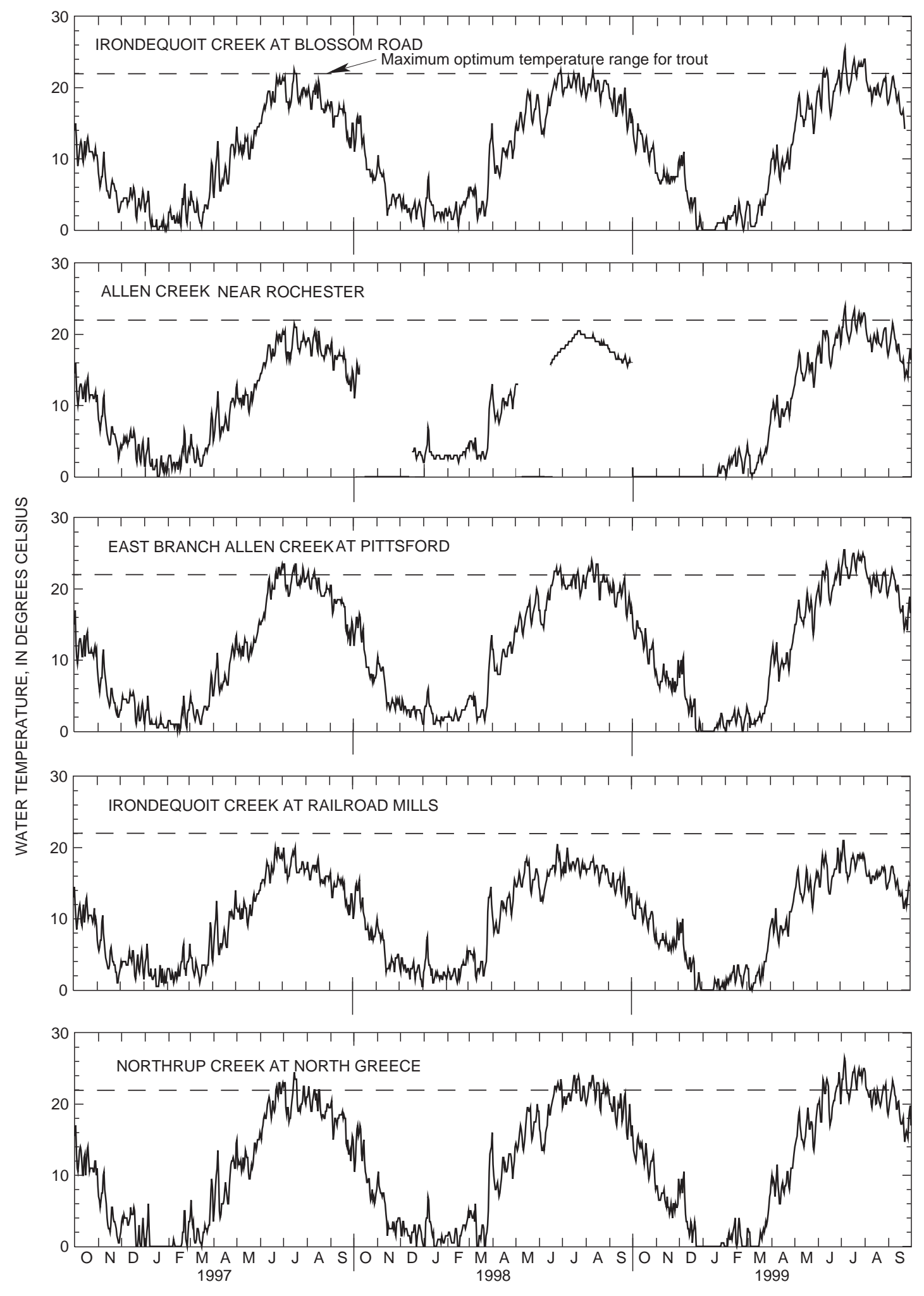

Figure 10. Daily mean water temperatures at four sites in the Irondequoit Creek basin and Northrup Creek, Monroe County, N.Y., water years 1997-99. (Locations are shown in fig. 1.) 
Table 8. Statistical summary and results of trend tests for streamflow at Northrup Creek and four sites in the Irondequoit Creek basin, Monroe County, N.Y., period of record through 1999.

[Mean, median, $25^{\text {th }}, 75^{\text {th }}$ percentiles, and trend units are in cubic feet per second. $p$, significance of trend. Bold type indicates trend is statistically significant at $\alpha=0.05$.]

\begin{tabular}{|c|c|c|c|c|c|c|c|c|c|c|c|}
\hline \multirow[b]{2}{*}{ Site } & \multirow[b]{2}{*}{$\begin{array}{l}\text { Period of } \\
\text { trend test }\end{array}$} & \multicolumn{5}{|c|}{ Descriptive statistics } & \multicolumn{5}{|c|}{ Trend results } \\
\hline & & $\begin{array}{c}\text { no. of } \\
\text { samples }\end{array}$ & Mean & $\begin{array}{c}25^{\text {th }} \\
\text { percentile }\end{array}$ & Median & $\begin{array}{c}75^{\text {th }} \\
\text { percentile }\end{array}$ & $\begin{array}{c}\text { no. of } \\
\text { seasons }\end{array}$ & $\begin{array}{c}\text { no. of } \\
\text { samples }\end{array}$ & $\begin{array}{l}\text { Units per } \\
\text { year }\end{array}$ & $\begin{array}{l}\text { Percent } \\
\text { per year }\end{array}$ & $p$ \\
\hline Northrup Creek & 1989-99 & 120 & 13.7 & 5.12 & 10.7 & 21.6 & 12 & 120 & 0.587 & 4.28 & 0.021 \\
\hline Railroad Mills & $1992-99$ & 96 & 39.2 & 20.6 & 31.0 & 51.0 & 12 & 96 & -.287 & -.732 & .474 \\
\hline East Branch Allen & $1991-99$ & 108 & 8.89 & 3.86 & 6.38 & 12.5 & 12 & 108 & .000 & .00 & 1.000 \\
\hline Allen Creek & 1984-99 & 192 & 29.2 & 14.9 & 22.2 & 39.7 & 12 & 192 & -.364 & -1.25 & .020 \\
\hline Blossom Road. & 1984-99 & 192 & 136 & 71.2 & 104 & 185 & 12 & 192 & -.448 & -.329 & .558 \\
\hline
\end{tabular}

monthly flows of Allen Creek for water years 1997-99 were above the normal range for January and July and below the normal range for April and May (fig. 12). As at Blossom Road, the high January mean flow was in response to the high flow event of January 8, 1998, which at this site did not produce a record peak. Monthly mean flows for water year 1997 were slightly above normal for October and December and below normal for April through August (fig. 11). Monthly mean flows at Allen Creek showed a wide variation for the 1998 water year - those for January and July were well above normal whereas those for April and May were well below normal. The wider variation in flows at Allen Creek is probably a result of the urban character of drainage area. Flows for the 1999 water year also varied widely - those for November, December, and April through August were below normal; only the mean flow for January was above normal. Annual mean flows at Allen Creek were above the long-term average for a sustained period (1968-79) in 1998 and below in 1997 and 1999 (fig. 14).

\section{Black Creek at Churchville}

Black Creek at Churchville (fig. 1) has a 54-year record, which was used to relate long-term flow conditions in western Monroe County (west of the Genesee River) to those in Northrup Creek during 1997-99. As at Blossom Road and Allen Creek, many of the mean monthly flows for the 1997-99 water years were outside the normal range (fig. 12). The 3-year mean monthly flow exceeded normal for October, November, January, and July, and was below normal for April. During the 1997 water year, monthly mean flow exceeded normal for October through December, February, and September, and was below normal only for April (fig. 11). Mean monthly flows for 1998 were above normal for all months except March, May and
June, during which they were in the normal range, and April, in which they were slightly below normal. In contrast, none of the mean monthly flows for the 1999 water year were above normal, and those for December and for April through July were below normal. Annual mean flows at Black Creek also were above the long-term average for a sustained period (1968-79) in 1997-98 and below in 1999

(fig. 14).

\section{Chemical Concentrations}

Streamflow was measured at all sites where water samples were collected, except the Genesee River at the Charlotte Pump station. Streamflow values for the Charlotte Pump station site were obtained from records for the Genesee River at Rochester (04232000), about 6 mi upstream. Water samples were collected hourly at each of the streamflow-gaging stations by automatic sampler. Samples collected at the upstream sites in the Irondequoit Creek basin and Northrup Creek, are combined into 2- to 4- day composite samples each quarter to produce a sample representing baseflow conditions and are composited for shorter periods of time over high flow events to produce approximately two high flow samples per month. Baseflow samples from all other sites are combined into 2- to 4- day composite samples to produce 1 to 2 baseflow samples per week and those collected during high flows are combined into 5 to 6 flow weighted composite samples that span the duration of the high flow event. Samples were analyzed for physical properties and for concentrations of nutrient species and common ions. For purposes of statistical evaluation, these composite samples are treated as discrete samples. Median constituent concentrations are shown in table 9. 

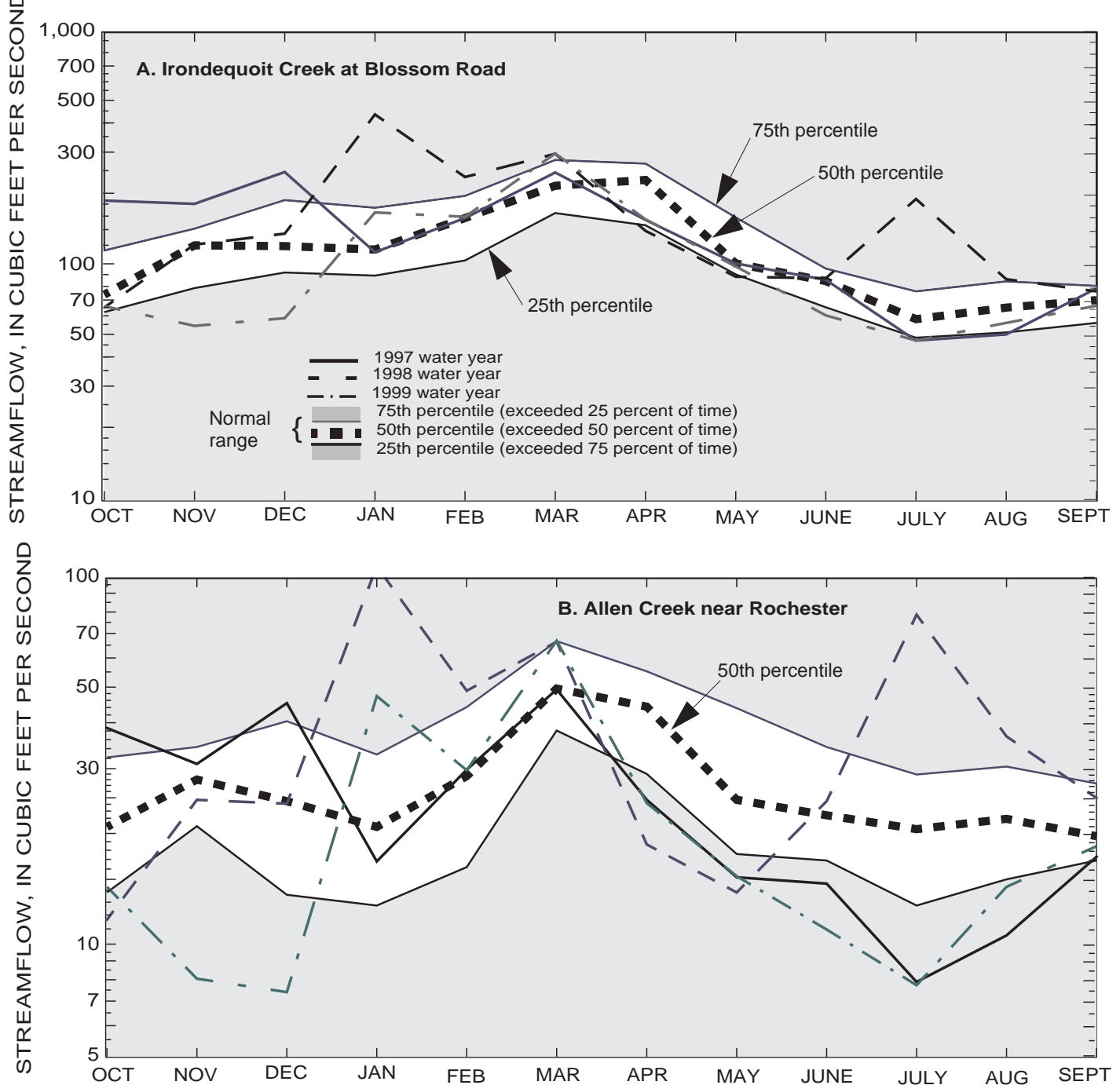

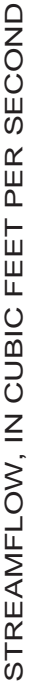

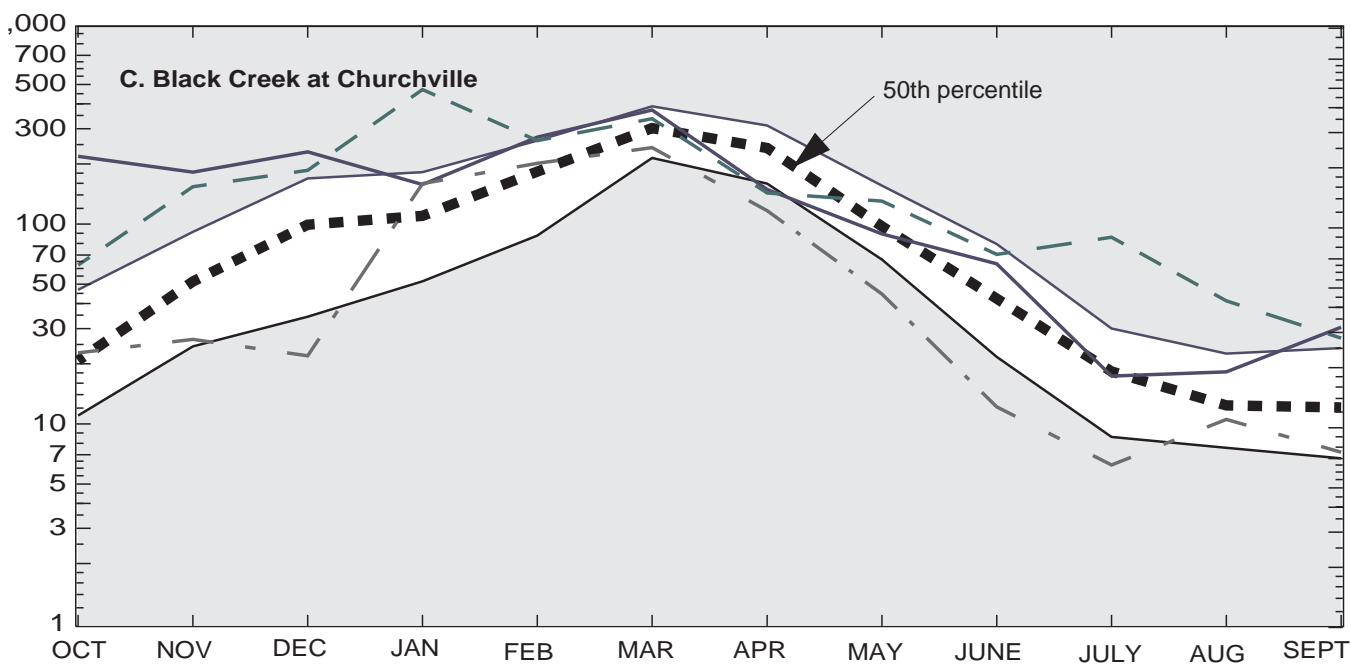

Figure 11. Monthly mean flow of three streams in Monroe County, N.Y., water years 1997, 1998, and 1999, in relation to normal range (flows between the 25th and 75th percentile) for period of record: A. Irondequoit Creek at Blossom Road. B. Allen Creek near Rochester. C. Black Creek at Churchville. (Location is shown in fig. 1.) 
A. Irondequoit Creek at Blossom Road
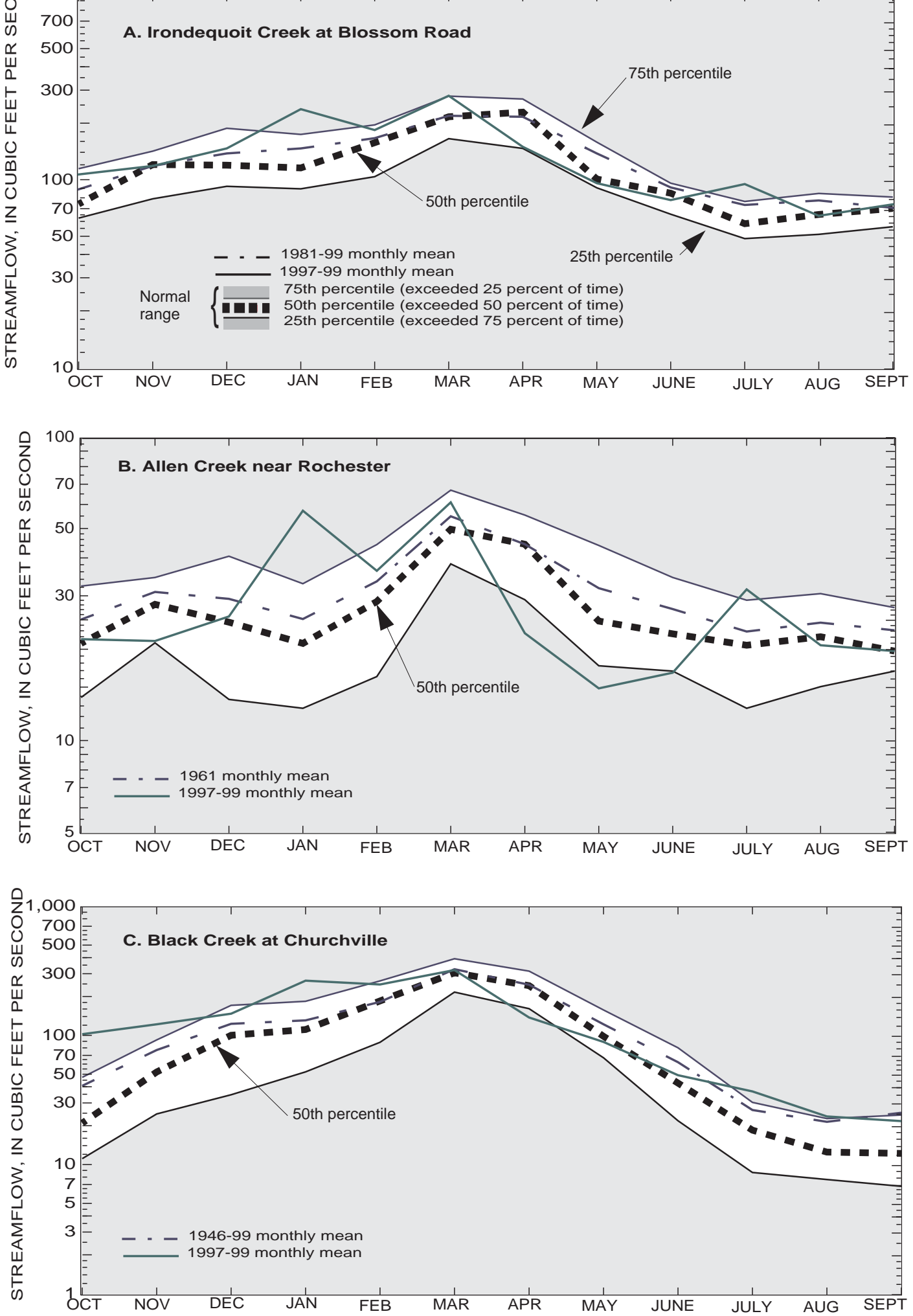

Figure 12. Mean monthly flows of three streams in Monroe County, N.Y., for period of record and three-year period, water years 1997-99, in relation to normal range (flows between the 25th and 75th percentile) for period of record: A. Irondequoit Creek at Blossom Road. B. Allen Creek near Rochester. C. Black Creek at Churchville. (Location is shown in fig. 1.) 


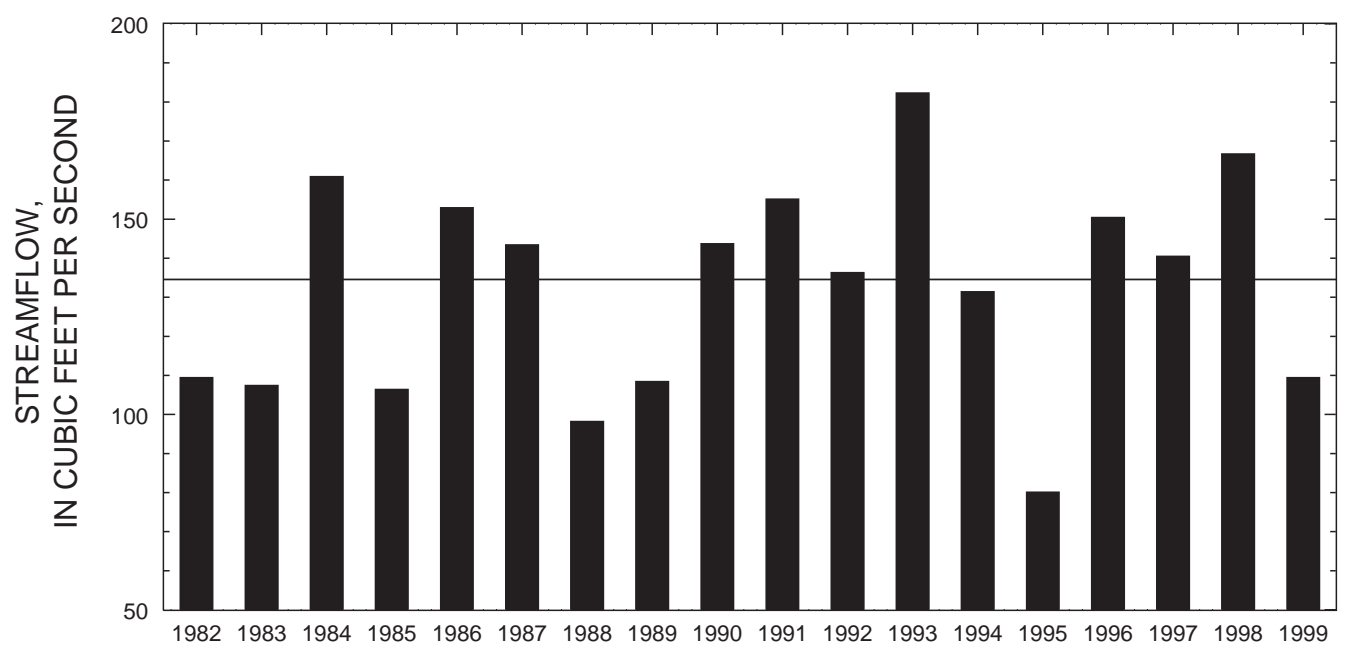

EXPLANATION

- Annual mean flow - Mean annual flow

Figure 13. Annual mean flow for Irondequoit Creek at Blossom Road, Rochester, N.Y., and mean annual flow for period of record. (Only complete water years are shown. Location is shown in fig. 1)

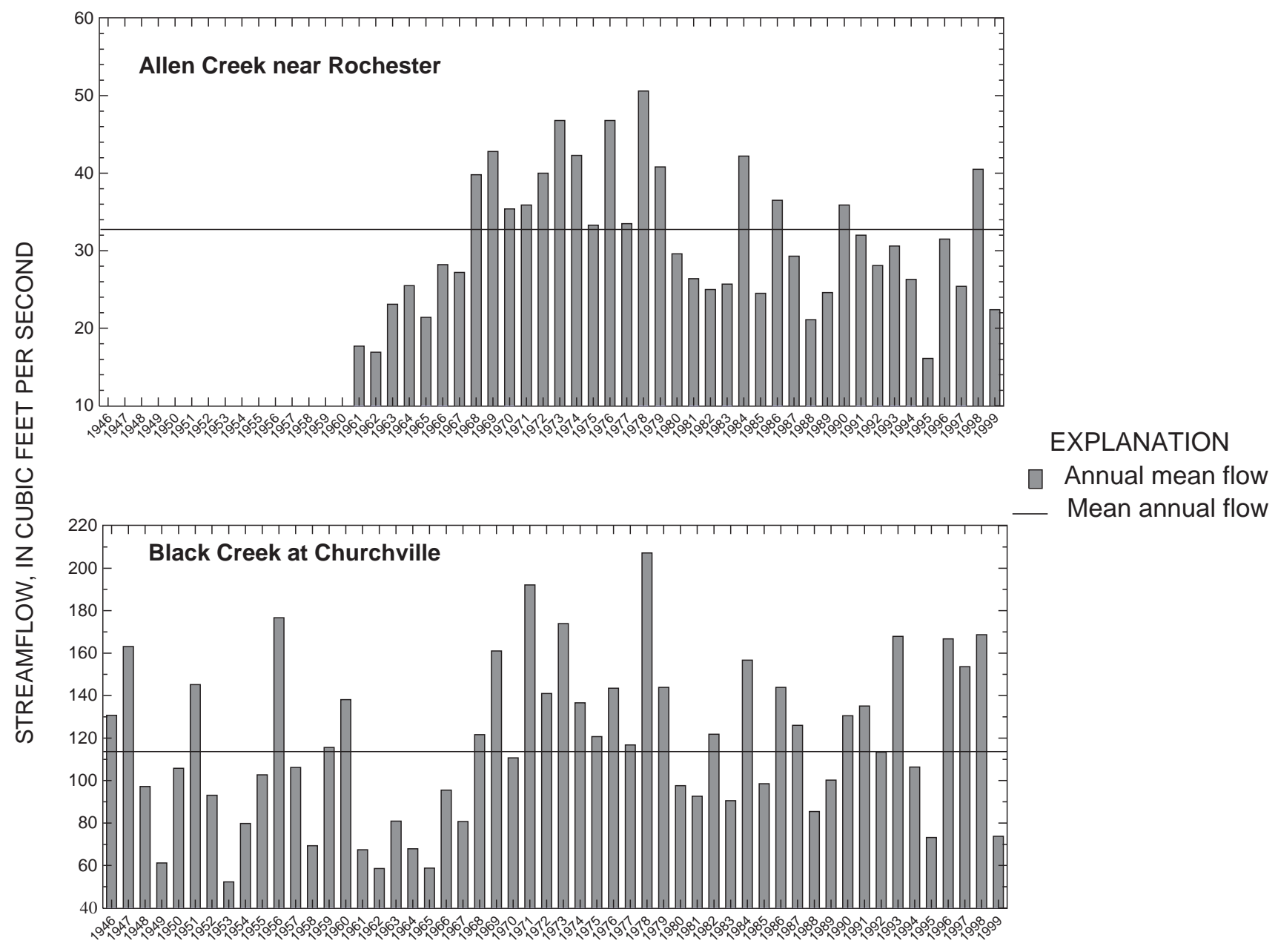

Figure 14. Annual mean flows for Allen Creek near Rochester and Black Creek at Churchville with mean annual flow for period of record. (Only complete water years are shown. Location is shown in fig. 1.) 
Table 9. Median concentrations of selected constituents at four sites in the Irondequoit Creek basin and four western sites in Monroe County, N.Y., water years 1997-99.

[Units are milligrams per liter unless otherwise noted. NTU, nephelometric turbidity units. Locations are shown in fig. 1.]

\begin{tabular}{|c|c|c|c|c|c|c|c|c|c|c|}
\hline Site & $\begin{array}{l}\text { Turbidity } \\
\text { (NTU) }\end{array}$ & $\begin{array}{l}\text { Total sus- } \\
\text { pended } \\
\text { solids }\end{array}$ & $\begin{array}{l}\text { Volatile } \\
\text { sus- } \\
\text { pended } \\
\text { solids }\end{array}$ & $\begin{array}{l}\text { Ammonia } \\
\text { as } \mathrm{N}, \\
\text { dissolved }\end{array}$ & $\begin{array}{c}\text { Ammonia } \\
\text { + organic } \\
\text { nitrogen } \\
\text { as } N \text {, } \\
\text { total }\end{array}$ & $\begin{array}{l}\text { Nitrite }+ \\
\text { nitrate as } \\
\mathrm{N} \text {, total }\end{array}$ & $\begin{array}{l}\text { Phos- } \\
\text { phorus } \\
\text { as P, } \\
\text { total }\end{array}$ & $\begin{array}{l}\text { Ortho- } \\
\text { phos- } \\
\text { phate } \\
\text { as P, } \\
\text { dissolved }\end{array}$ & $\begin{array}{l}\text { Chloride, } \\
\text { dissolved }\end{array}$ & $\begin{array}{l}\text { Sulfate, } \\
\text { dissolved }\end{array}$ \\
\hline \multicolumn{11}{|c|}{ Irondequoit Creek basin sites } \\
\hline $\begin{array}{l}\text { Irondequoit Creek at } \\
\text { Railroad Mills }\end{array}$ & 17 & 136 & 17 & 0.01 & 0.34 & 1.1 & 0.075 & 0.008 & 74 & 152 \\
\hline $\begin{array}{l}\text { East Branch Allen } \\
\text { Creek at Pittsford }\end{array}$ & 16 & 108 & 15 & .02 & .51 & .71 & .095 & .020 & 108 & 79 \\
\hline $\begin{array}{l}\text { Allen Creek near } \\
\text { Rochester }\end{array}$ & 11 & 139 & 19 & .02 & .49 & .88 & .085 & .018 & 158 & 58 \\
\hline $\begin{array}{l}\text { Irondequoit Creek at } \\
\text { Blossom Road }\end{array}$ & 11 & 96 & 14 & .01 & .45 & 1.0 & .075 & .012 & 123 & 133 \\
\hline \multicolumn{11}{|c|}{ Western Monroe County sites } \\
\hline $\begin{array}{l}\text { Northrup Creek at } \\
\text { North Greece }\end{array}$ & 13 & 114 & 17 & .06 & .80 & 1.3 & .15 & .050 & 90 & 49 \\
\hline $\begin{array}{l}\text { Honeoye Creek at } \\
\text { Honeoye Falls }\end{array}$ & 6.6 & 86 & 10 & .01 & .34 & .08 & .045 & .010 & 30 & 22 \\
\hline $\begin{array}{l}\text { Oatka Creek at } \\
\text { Garbutt }\end{array}$ & 3.0 & 7 & 5 & .02 & .35 & 1.4 & .03 & .007 & 47 & 279 \\
\hline $\begin{array}{l}\text { Black Creek at } \\
\text { Churchville }\end{array}$ & 3.6 & 78 & 24 & .03 & .60 & .80 & .06 & .12 & 53 & 253 \\
\hline
\end{tabular}

\section{Spatial Variability}

Chemical variability among streams is generally a result of the land use in the basin. For example, median concentrations of dissolved chloride are higher at the downstream sites that drain urbanized areas than at the upstream sites, which drain more agricultural land.

\section{Erie (Barge) Canal Diversions}

Water from the Erie (Barge) canal is used to supplement flow in some streams north of the canal during the canal navigation season, from about April 15 to about November 15. Water diverted from the canal is used to maintain minimum flows in the streams during low-flow periods for dilution of sewage-treatment-plant discharges, for irrigation, and to help maintain canal pool elevation. The Monroe County Environmental Health Laboratory (MCEHL) has been sampling these diversions (water is diverted by siphons) at Allen Creek, East Branch Allen Creek, the Cartersville waste channel, which diverts water from the canal to Irondequoit Creek, and at the Fairport waste channel, which diverts water from the canal to Irondequoit Creek through Thomas Creek, since 1986 (fig. 2). Samples are collected at Allen Creek and East Branch Allen Creek, immediately upstream of the siphon, at the siphon, and immediately downstream of the siphon. The East Branch Allen Creek canal siphon is about $1.1 \mathrm{mi}$ upstream of the monitoring site on East Branch Allen Creek, and the Allen Creek siphon is about $4.6 \mathrm{mi}$ upstream of the monitoring site on Allen Creek (fig. 2). Cartersville and Fairport samples are collected directly from the waste channels. Median concentrations of constituents at the Allen Creek and East Branch Allen Creek sites for the period of record are plotted in figure 15.

Median concentrations of turbidity, total suspended solids, volatile suspended solids, nitrite + nitrate, and sulfate were significantly higher in samples from the canal siphon at East Branch Allen Creek than in samples collected immediately upstream of the siphon (table 10). This resulted in significantly higher median concentration of these constituents just downstream of the siphon. Concentrations of ammonia + organic nitrogen, orthophosphate, and chloride were lower at the siphon than at the upstream site, this resulted in lower concentrations through dilution of these constituents at the downstream site than at the upstream site. The only constituent to show a statistically significant lower concentration at the siphon and, consequently, at the downstream site than at the upstream site was chloride. The median concentration of orthophosphate was significantly lower at the siphon than upstream, which resulted in a lower (although not significant) median concentration 

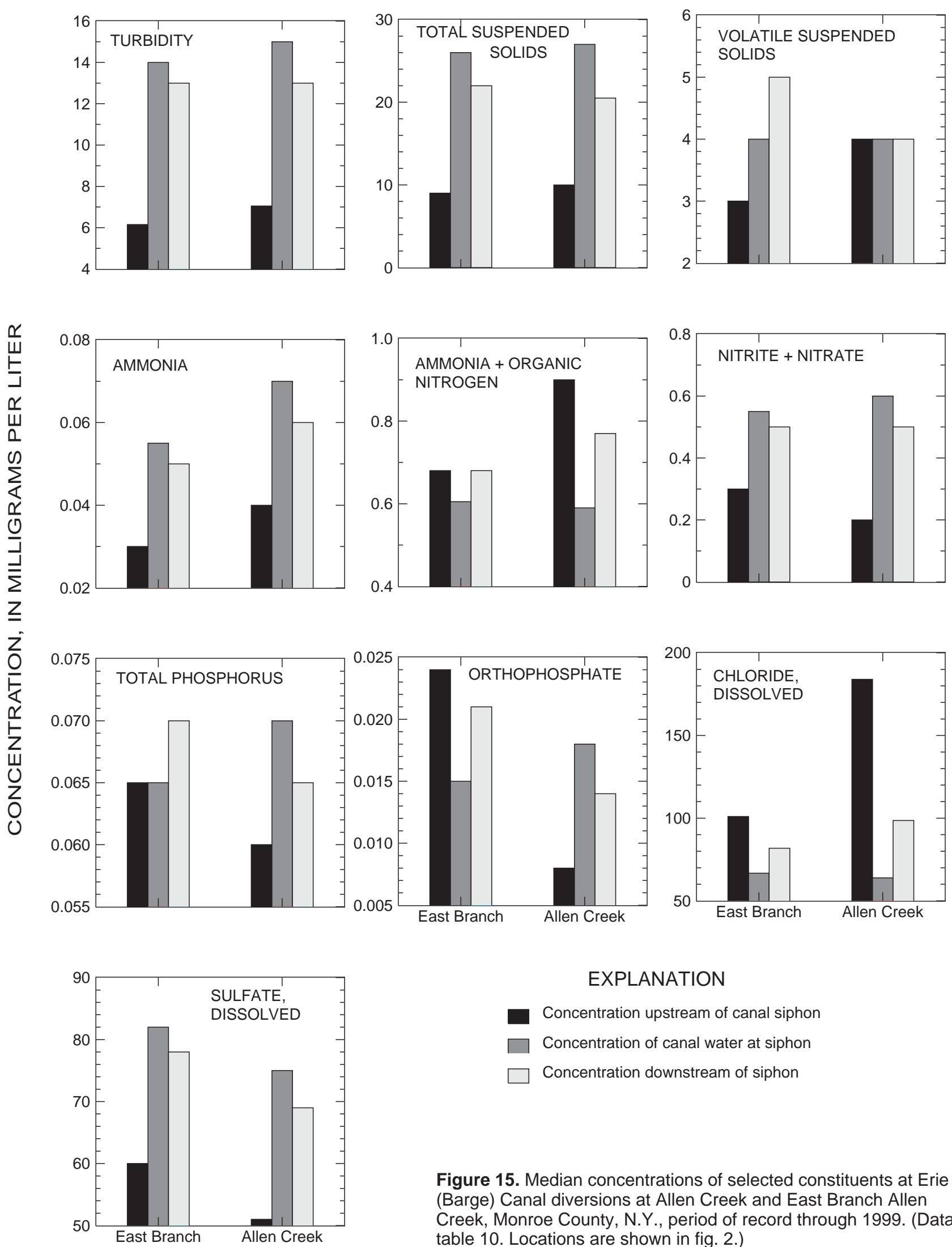

Figure 15. Median concentrations of selected constituents at Erie (Barge) Canal diversions at Allen Creek and East Branch Allen Creek, Monroe County, N.Y., period of record through 1999. (Data in table 10. Locations are shown in fig. 2.) 
Table 10. Median concentrations of selected constituents at Erie (Barge) Canal diversions on East Branch Allen Creek, Allen Creek, and Irondequoit Creek, Monroe County, N.Y., period of record through 1999.

[Units are milligrams per liter unless otherwise noted. NTU, nephelometric turbidity units. Locations are shown in fig. 2.]

\begin{tabular}{|c|c|c|c|c|c|c|c|c|c|c|}
\hline Site & $\begin{array}{l}\text { Turbidity } \\
\text { (NTU) }\end{array}$ & $\begin{array}{l}\text { Total sus- } \\
\text { pended } \\
\text { solids }\end{array}$ & $\begin{array}{l}\text { Volatile } \\
\text { sus- } \\
\text { pended } \\
\text { solids }\end{array}$ & $\begin{array}{l}\text { Ammonia } \\
\text { as N, } \\
\text { dissolved }\end{array}$ & $\begin{array}{l}\text { Ammonia } \\
\text { +organic } \\
\text { nitrogen } \\
\text { as } N \text {, } \\
\text { total }\end{array}$ & $\begin{array}{c}\text { Nitrite + } \\
\text { nitrate as } \\
\mathrm{N} \text {, total }\end{array}$ & $\begin{array}{l}\text { Phos- } \\
\text { phorus } \\
\text { as P } \\
\text { total }\end{array}$ & $\begin{array}{l}\text { Ortho- } \\
\text { phos- } \\
\text { phate } \\
\text { as P, } \\
\text { dissolved }\end{array}$ & $\begin{array}{l}\text { Chloride, } \\
\text { dissolved }\end{array}$ & $\begin{array}{l}\text { Sulfate, } \\
\text { dissolved }\end{array}$ \\
\hline \multicolumn{11}{|c|}{ East Branch Allen Creek canal sites } \\
\hline above siphon & 6.15 & 9.0 & 3.0 & 0.030 & 0.68 & 0.30 & 0.065 & 0.024 & 101 & 60 \\
\hline at siphon & 14.0 & 26.0 & 4.0 & .055 & .60 & .55 & .065 & .015 & 67 & 82 \\
\hline below siphon & 13.0 & 22.0 & 5.0 & .050 & .68 & .50 & .070 & .021 & 82 & 78 \\
\hline \multicolumn{11}{|l|}{ Allen Creek canal sites } \\
\hline above siphon & 7.05 & 10.0 & 4.0 & .040 & .90 & .20 & .060 & .008 & 184 & 51 \\
\hline at siphon & 15.0 & 27.0 & 4.0 & .070 & .59 & .60 & .070 & .018 & 64 & 75 \\
\hline below siphon & 13.0 & 20.5 & 4.0 & .060 & .77 & .50 & .065 & .014 & 99 & 69 \\
\hline \multicolumn{11}{|c|}{ Irondequoit Creek canal sites } \\
\hline Cartersville waste & 13.0 & 21.5 & 4.0 & .038 & .51 & .70 & .066 & .024 & 64 & 82 \\
\hline Fairport waste & 5.4 & 10.0 & 3.0 & .050 & .56 & .50 & .065 & .019 & 72 & 87 \\
\hline
\end{tabular}

Table 11. Median values of instantaneous flow and nutrient loads at Erie (Barge) Canal diversions on East Branch Allen Creek, and Allen Creek, Monroe County, N.Y. period of record through 1999.

[Units are pounds per day unless otherwise noted. Locations are shown in fig. 2.]

\begin{tabular}{|c|c|c|c|c|c|c|}
\hline Site & $\begin{array}{c}\text { Discharge } \\
\text { (cubic feet } \\
\text { per } \\
\text { second) }\end{array}$ & $\begin{array}{l}\text { Ammonia } \\
\text { as N, } \\
\text { dissolved }\end{array}$ & $\begin{array}{c}\text { Ammonia } \\
\text { + organic } \\
\text { nitrogen } \\
\text { as } N, \\
\text { total }\end{array}$ & $\begin{array}{c}\text { Nitrite + } \\
\text { nitrate as } \\
\mathrm{N} \text {, total }\end{array}$ & $\begin{array}{l}\text { Phos- } \\
\text { phorus } \\
\text { as P, total }\end{array}$ & $\begin{array}{c}\text { Ortho- } \\
\text { phos- } \\
\text { phate } \\
\text { as P, } \\
\text { dissolved }\end{array}$ \\
\hline \multicolumn{7}{|c|}{ East Branch Allen Creek canal sites } \\
\hline above siphon & 0.62 & 0.081 & 2.16 & 1.78 & 0.24 & 0.052 \\
\hline at siphon & 2.3 & .675 & 5.03 & 6.21 & .76 & .286 \\
\hline below siphon & 2.6 & .562 & 8.37 & 8.75 & 1.08 & .322 \\
\hline \multicolumn{7}{|c|}{ Allen Creek canal sites } \\
\hline above siphon & 1.15 & .186 & 3.72 & 1.3 & .39 & .043 \\
\hline at siphon & 1.75 & .383 & 3.98 & 4.86 & .59 & .134 \\
\hline below siphon & 2.85 & 697 & 11.2 & 6.21 & 1.07 & .198 \\
\hline
\end{tabular}

downstream. Similar results were noted at the canal diversion at Allen Creek. Here the median concentrations of ammonia were significantly higher at the siphon and the downstream site than at the upstream site, whereas concentrations of ammonia + organic nitrogen were significantly lower at the siphon and downstream site than at the upstream site.

Instantaneous nutrient loads-obtained by multiplying concentration by the corresponding flow and by a conversion factor that converts milligrams per liter and cubic feet per second to pounds per day-were calculated for the point upstream of the canal siphon, the canal siphon, and the point downstream of the siphon at the East Branch Allen Creek and Allen Creek sites (table 11). Even though median concentrations (fig. 15) of some nutrients such as ammonia + organic nitrogen, total phosphorus and orthophosphate in discharge from the canal at East Branch Allen Creek were the same as, or lower than, in water just upstream of the siphon, median loads of these constituents at points downstream of the siphon were greater than those upstream (fig. 16) because water from the canal is the main component of the flow in the stream at that point. Similar results were found at the canal sampling points on Allen Creek. Thus, the diversion from the canal is the main contributor of nutrients to the reaches of East Branch Allen Creek and Allen Creek below the siphons for periods of base flow during the navigation season.

Median concentrations of constituents at the Fairport waste channel and the Cartersville waste channel are included in table 10. Unlike East Branch 

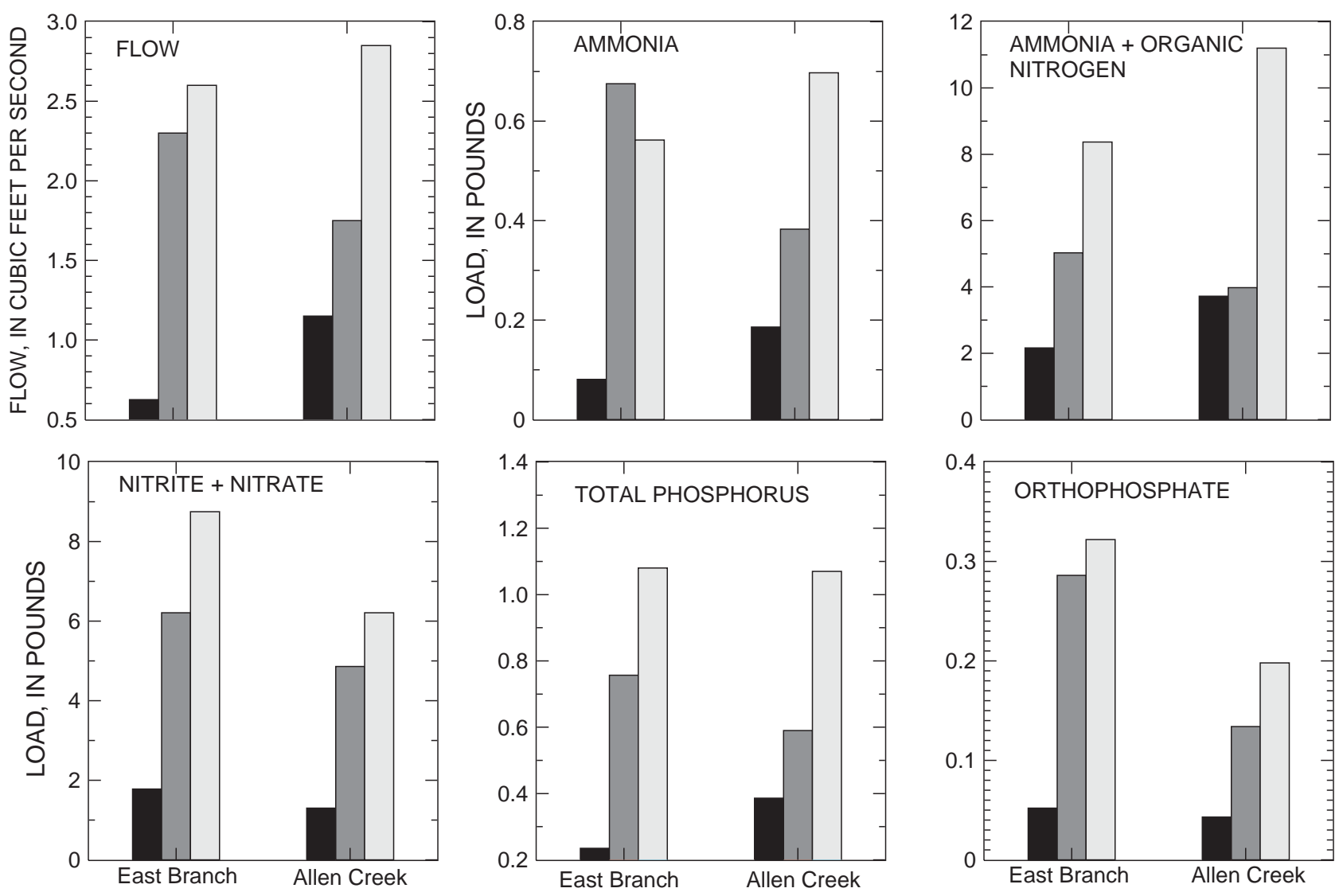

EXPLANATION

Constituent load upstream of canal siphon

$\square$ Constituent load at canal siphon

Constituent load below canal siphon
Figure 16. Median values of instantaneous flow and nutrient loads at Erie (Barge) Canal diversions at East Branch Allen Creek and Allen Creek, Monroe County, N.Y., period of record through 1999. (Data in table 11. Locations are shown in fig. 2.)
Allen Creek and Allen Creek, the canal diversions from those sites to Irondequoit Creek have no sampling sites immediately upstream and downstream of the diversions by which to assess the relative impact of canal water on constituent concentrations in Irondequoit Creek.

Differences in median and range of concentration of selected constituents from the Irondequoit basin sites and the sites west of the Genesee River were examined through boxplots (fig. 17) and Tukey's MCT (multiple comparison test) on ranks of the concentration data to identify significant $(\alpha=0.05)$ differences among sites in mean concentration. The results are summarized in table 12. Differences in median concentration of constituents among sites for the period of record through 1996 and for 1997-99 are illustrated in figure 18 .

\section{Irondequoit Creek Basin Sites}

Differences in median concentration of some constituents were noted among Irondequoit Creek subbasins as well as between time periods. The median is often used as a measure of central tendency rather than the mean because it is not influenced by extreme values, as the mean is.

Nutrients: Median concentrations of nutrients during 1997-99 were fairly uniform among all sites (table 9). Nitrite + nitrate showed the greatest range in concentration-from $0.71 \mathrm{mg} / \mathrm{L}$ at East Branch Allen Creek to $1.1 \mathrm{mg} / \mathrm{L}$ at Irondequoit Creek at Railroad Mills, which had the lowest concentration $(0.34 \mathrm{mg} / \mathrm{L})$ of ammonia + organic nitrogen. The highest median concentration of ammonia + organic nitrogen $(0.51 \mathrm{mg} / \mathrm{L})$ was at East Branch Allen Creek. Median concentrations of total phosphorus and orthophosphate differed little among sites ( 0.075 to $0.095 \mathrm{mg} / \mathrm{L}$ and 0.008 to $0.020 \mathrm{mg} / \mathrm{L}$, respectively). The constituents 

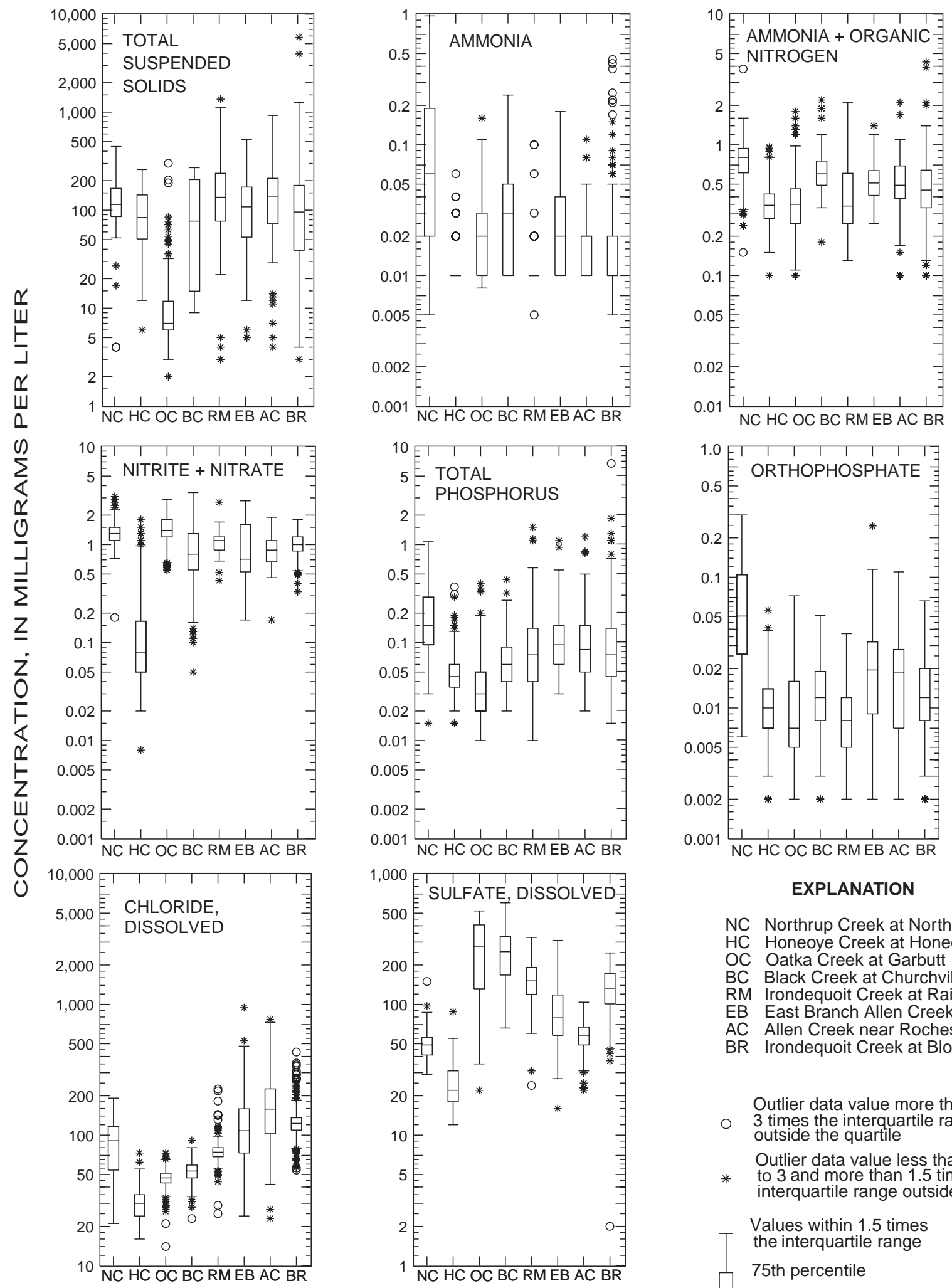

\section{EXPLANATION}

NC Northrup Creek at North Greece HC Honeoye Creek at Honeoye Falls OC Oatka Creek at Garbutt BC Black Creek at Churchville RM Irondequoit Creek at Railroad Mills EB East Branch Allen Creek at Pittsford AC Allen Creek near Rochester BR Irondequoit Creek at Blossom Road

Outlier data value more than

- 3 times the interquartile range outside the quartile

Outlier data value less than or equal

* to 3 and more than 1.5 times the interquartile range outside the quartile

Values within 1.5 times

$T$ the interquartile range

75th percentile

Median

25th percentile

Figure 17. Ranges in concentration of selected constituents in samples from four Irondequoit Creek basin sites, Northrup Creek, and three other sites in western Monroe County, N.Y., water years 1997-99. (Locations are shown in fig. 1.) 
Table 12. Results of Tukey's Multiple Comparison Test (MCT) showing statistically significant $(\alpha=0.05)$ differences in mean concentrations of selected constituents among Irondequoit Creek basin sites and Northrup Creek, Monroe County, N.Y., water years 1997-99.

[H indicates value for boldface site is significantly higher; $\mathrm{L}$ indicates value for boldface site is significantly lower; ND; no significant difference. Locations are shown in fig. 1.]

\begin{tabular}{|c|c|c|c|c|c|c|c|c|c|c|}
\hline Site & Turbidity & $\begin{array}{l}\text { Total } \\
\text { sus- } \\
\text { pended } \\
\text { solids }\end{array}$ & $\begin{array}{l}\text { Volatile } \\
\text { sus- } \\
\text { pended } \\
\text { solids }\end{array}$ & $\begin{array}{l}\text { Ammonia, } \\
\text { dissolved }\end{array}$ & $\begin{array}{l}\text { Ammonia } \\
\text { + organic } \\
\text { nitrogen, } \\
\text { total }\end{array}$ & $\begin{array}{c}\text { Nitrite + } \\
\text { nitrate, } \\
\text { total }\end{array}$ & $\begin{array}{l}\text { Phos- } \\
\text { phorus, } \\
\text { total }\end{array}$ & $\begin{array}{l}\text { Ortho- } \\
\text { phos- } \\
\text { phate, } \\
\text { dissolved }\end{array}$ & $\begin{array}{l}\text { Chloride, } \\
\text { dissolved }\end{array}$ & $\begin{array}{l}\text { Sulfate, } \\
\text { dissolved }\end{array}$ \\
\hline \multicolumn{11}{|c|}{ Irondequoit Creek at Blossom Road in relation to: } \\
\hline Irondequoit Creek at Railroad Mills & $\mathrm{L}$ & ND & ND & ND & ND & ND & ND & $\mathrm{H}$ & $\mathrm{H}$ & $\mathrm{L}$ \\
\hline East Branch Allen Creek at Pittsford & $\mathrm{L}$ & ND & ND & $\mathrm{L}$ & ND & ND & $\mathrm{L}$ & $\mathrm{H}$ & $\mathrm{H}$ & $\mathrm{H}$ \\
\hline Allen Creek near Rochester & ND & ND & ND & ND & ND & $\mathrm{H}$ & ND & $\mathrm{L}$ & $\mathrm{L}$ & $\mathrm{H}$ \\
\hline Northrup Creek at North Greece & ND & ND & ND & $\mathrm{L}$ & $\mathrm{L}$ & $\mathrm{L}$ & $\mathrm{L}$ & $\mathrm{L}$ & $\mathrm{H}$ & $\mathrm{H}$ \\
\hline Black Creek at Churchville & $\mathrm{H}$ & ND & ND & $\mathrm{L}$ & $\mathrm{L}$ & $\mathrm{H}$ & $\mathrm{H}$ & ND & $\mathrm{H}$ & $\mathrm{L}$ \\
\hline Oatka Creek at Garbutt & $\mathrm{H}$ & $\mathrm{H}$ & $\mathrm{H}$ & $\mathrm{L}$ & $\mathrm{H}$ & $\mathrm{H}$ & $\mathrm{H}$ & $\mathrm{H}$ & $\mathrm{H}$ & $\mathrm{H}$ \\
\hline Honeoye Creek at Honeoye Falls & $\mathrm{H}$ & ND & ND & ND & $\mathrm{H}$ & $\mathrm{H}$ & $\mathrm{H}$ & ND & $\mathrm{H}$ & $\mathrm{H}$ \\
\hline \multicolumn{11}{|c|}{ Irondequoit Creek at Railroad Mills in relation to: } \\
\hline East Branch Allen Creek at Pittsford & ND & ND & ND & $\mathrm{L}$ & $\mathrm{L}$ & ND & $\mathrm{L}$ & $\mathrm{L}$ & $\mathrm{L}$ & $\mathrm{H}$ \\
\hline Allen Creek near Rochester & $\mathrm{H}$ & ND & ND & $\mathrm{L}$ & ND & ND & ND & $\mathrm{L}$ & $\mathrm{L}$ & $\mathrm{H}$ \\
\hline Northrup Creek at North Greece & ND & ND & ND & $\mathrm{L}$ & $\mathrm{L}$ & $\mathrm{L}$ & $\mathrm{L}$ & $\mathrm{L}$ & ND & $\mathrm{H}$ \\
\hline Black Creek at Churchville & $\mathrm{H}$ & ND & ND & $\mathrm{L}$ & $\mathrm{L}$ & $\mathrm{H}$ & ND & $\mathrm{L}$ & $\mathrm{H}$ & $\mathrm{H}$ \\
\hline Oatka Creek at Garbutt & $\mathrm{H}$ & $\mathrm{H}$ & $\mathrm{H}$ & $\mathrm{L}$ & ND & ND & $\mathrm{H}$ & ND & $\mathrm{H}$ & $\mathrm{H}$ \\
\hline Honeoye Creek at Honeoye Falls & $\mathrm{H}$ & ND & ND & ND & ND & $\mathrm{H}$ & $\mathrm{H}$ & ND & $\mathrm{H}$ & $\mathrm{H}$ \\
\hline \multicolumn{11}{|c|}{ Northrup Creek at North Greece in relation to: } \\
\hline East Branch Allen Creek at Pittsford & ND & ND & ND & $\mathrm{H}$ & $\mathrm{H}$ & $\mathrm{H}$ & $\mathrm{H}$ & $\mathrm{H}$ & $\mathrm{L}$ & $\mathrm{L}$ \\
\hline Allen Creek near Rochester & ND & ND & ND & $\mathrm{H}$ & $\mathrm{H}$ & $\mathrm{H}$ & $\mathrm{H}$ & $\mathrm{H}$ & $\mathrm{L}$ & ND \\
\hline Black Creek at Churchville & $\mathrm{H}$ & ND & ND & $\mathrm{H}$ & $\mathrm{H}$ & ND & $\mathrm{H}$ & $\mathrm{H}$ & $\mathrm{H}$ & $\mathrm{L}$ \\
\hline Oatka Creek at Garbutt & $\mathrm{H}$ & $\mathrm{H}$ & $\mathrm{H}$ & $\mathrm{H}$ & $\mathrm{H}$ & $\mathrm{H}$ & $\mathrm{H}$ & $\mathrm{H}$ & $\mathrm{H}$ & $\mathrm{L}$ \\
\hline Honeoye Creek at Honeoye Falls & $\mathrm{H}$ & ND & ND & $\mathrm{H}$ & $\mathrm{H}$ & $\mathrm{H}$ & $\mathrm{H}$ & $\mathrm{H}$ & $\mathrm{H}$ & $\mathrm{H}$ \\
\hline \multicolumn{11}{|c|}{ East Branch Allen Creek at Pittsford in relation to: } \\
\hline Allen Creek near Rochester & $\mathrm{H}$ & ND & ND & $\mathrm{H}$ & ND & ND & ND & ND & $\mathrm{L}$ & $\mathrm{H}$ \\
\hline Black Creek at Churchville & $\mathrm{H}$ & ND & ND & ND & $\mathrm{L}$ & ND & $\mathrm{H}$ & $\mathrm{H}$ & $\mathrm{H}$ & $\mathrm{L}$ \\
\hline Oatka Creek at Garbutt & $\mathrm{H}$ & $\mathrm{H}$ & $\mathrm{H}$ & $\mathrm{H}$ & $\mathrm{H}$ & $\mathrm{L}$ & $\mathrm{H}$ & $\mathrm{H}$ & $\mathrm{H}$ & $\mathrm{L}$ \\
\hline Honeoye Creek at Honeoye Falls & $\mathrm{H}$ & ND & ND & $\mathrm{H}$ & $\mathrm{H}$ & $\mathrm{H}$ & $\mathrm{H}$ & $\mathrm{H}$ & $\mathrm{H}$ & $\mathrm{H}$ \\
\hline \multicolumn{11}{|c|}{ Allen Creek near Rochester in relation to: } \\
\hline Black Creek at Churchville & $\mathrm{H}$ & ND & ND & $\mathrm{L}$ & $\mathrm{L}$ & ND & $\mathrm{H}$ & $\mathrm{H}$ & $\mathrm{H}$ & $\mathrm{L}$ \\
\hline Oatka Creek at Garbutt & $\mathrm{H}$ & $\mathrm{H}$ & $\mathrm{H}$ & ND & $\mathrm{H}$ & $\mathrm{L}$ & $\mathrm{H}$ & $\mathrm{H}$ & $\mathrm{H}$ & $\mathrm{L}$ \\
\hline Honeoye Creek at Honeoye Falls & $\mathrm{H}$ & ND & ND & $\mathrm{L}$ & $\mathrm{H}$ & $\mathrm{H}$ & $\mathrm{H}$ & $\mathrm{H}$ & $\mathrm{H}$ & $\mathrm{H}$ \\
\hline \multicolumn{11}{|c|}{ Black Creek at Churchville in relation to: } \\
\hline Oatka Creek at Garbutt & ND & ND & $\mathrm{H}$ & $\mathrm{H}$ & $\mathrm{H}$ & $\mathrm{L}$ & $\mathrm{H}$ & $\mathrm{H}$ & $\mathrm{L}$ & $\mathrm{H}$ \\
\hline Honeoye Creek at Honeoye Falls & $\mathrm{L}$ & ND & ND & $\mathrm{H}$ & $\mathrm{H}$ & $\mathrm{H}$ & $\mathrm{H}$ & ND & $\mathrm{H}$ & $\mathrm{H}$ \\
\hline \multicolumn{11}{|c|}{ Oatka Creek at Garbutt in relation to: } \\
\hline Honeoye Creek at Honeoye Falls & $\mathrm{L}$ & $\mathrm{L}$ & $\mathrm{L}$ & $\mathrm{H}$ & ND & $\mathrm{H}$ & $\mathrm{H}$ & $\mathrm{H}$ & $\mathrm{H}$ & $\mathrm{H}$ \\
\hline Total significant differences & 21 & 6 & 7 & 22 & 20 & 19 & 23 & 22 & 27 & 27 \\
\hline
\end{tabular}

with the greatest number of significant differences among sites were phosphorus, ammonia, and orthophosphate, with 22 or 23 differences each (table 12).

Chloride and Sulfate: The highest median concentrations of chloride for 1997-99 as well as the previous periods have occurred at Allen Creek, where the median concentration for $1997-99$ was $158 \mathrm{mg} / \mathrm{L}$. The highest median concentration of sulfate $(152 \mathrm{mg} / \mathrm{L})$ for 1997-99 was at Irondequoit Creek at Railroad Mills which also has had the highest median concentrations in the past. The differences in chloride concentration among sites is related to the amount and rate of roadsalt application; thus, sites that represent the most 

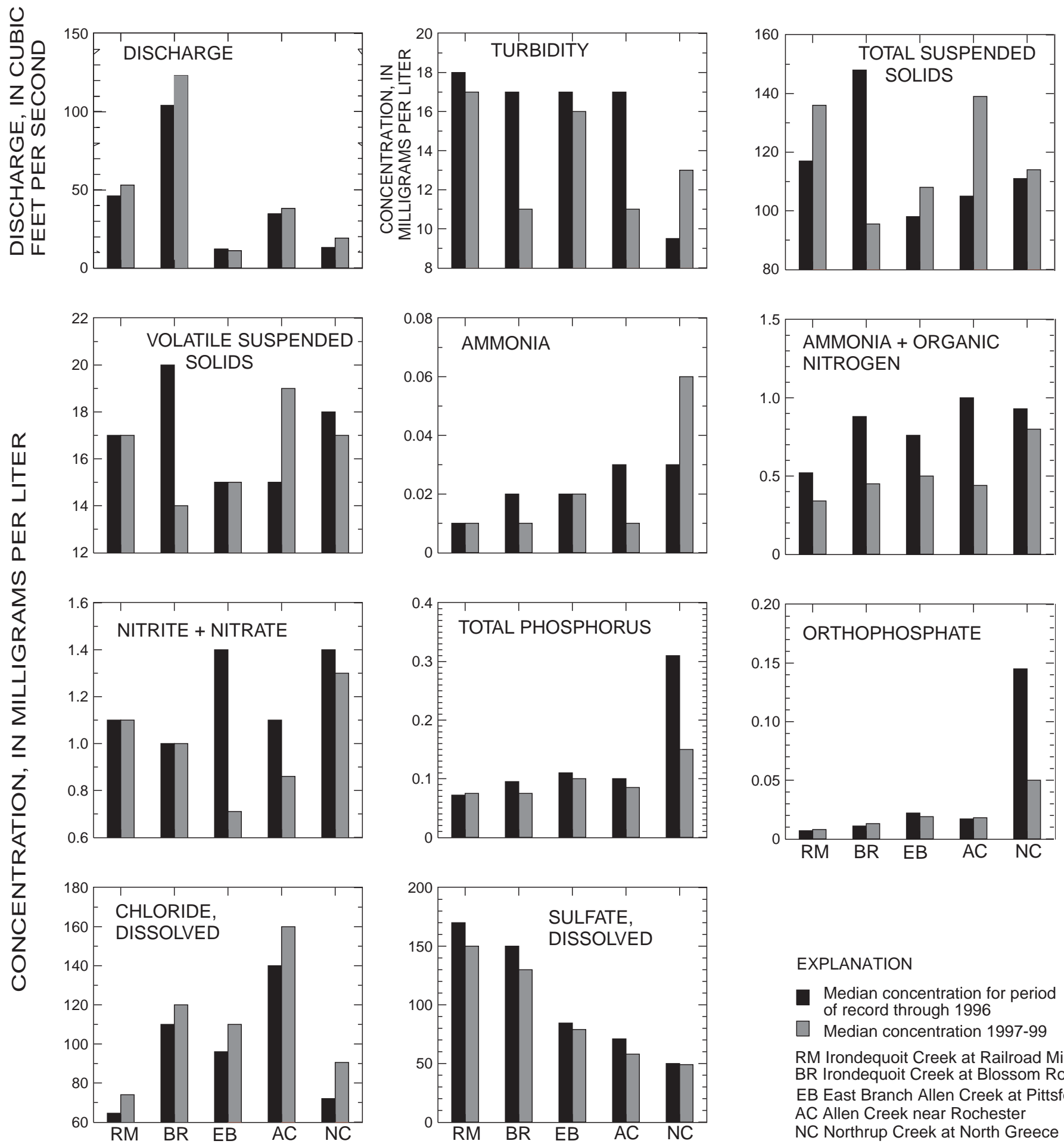

\section{EXPLANATION}

Median concentration for period of record through 1996

$\square$ Median concentration 1997-99

RM Irondequoit Creek at Railroad Mills BR Irondequoit Creek at Blossom Road EB East Branch Allen Creek at Pittsford AC Allen Creek near Rochester NC Northrup Creek at North Greece

Figure 18. Median concentrations of selected constituents in samples from four Irondequoit Creek basin sites and Northrup Creek, Monroe County, N.Y., for the period of record through 1996 and 1997-99. (Locations are shown in fig. 1.) 
urbanized subbasins (those with the highest road density) show the highest median concentrations. The high concentrations of sulfate at the Irondequoit sites result from the dissolution of sulfate from the local glacial deposits and from the shale bedrock that underlies much of the area (Young, 1993). Median concentrations of chloride and sulfate showed significant differences among most of the sites (table 12). Median concentrations of chloride for all Irondequoit basin sites were higher in the 1997-99 than in the previous period of record, whereas median sulfate concentrations for 1997-99 at all sites were lower (fig. 18).

Suspended Solids: The median concentrations for 1997-99 of total suspended solids were highest at Allen Creek and Railroad Mills (139 and 136 mg/L, respectively), and were lowest at Blossom Road. Median concentrations of volatile (the organic fraction of suspended solids) suspended solids were fairly uniform throughout the Irondequoit basin sites, and ranged from $14 \mathrm{mg} / \mathrm{L}$ at Blossom Road to $19 \mathrm{mg} / \mathrm{L}$ at Allen Creek. The lower concentrations at the downstream sites result from the settling out of these constituents as stream gradients decrease. The 30-percent decrease in median concentrations of total and volatile suspended solids at Blossom Road may result partly because of the stabilization of a length of stream bank along Irondequoit Creek in Linear Park (fig. 2.).

\section{Western Monroe County Sites}

Median concentrations of turbidity, total suspended solids, and volatile suspended solids at the sites representing primarily agricultural subbasins in western Monroe County were lower than at sites in the Irondequoit Creek basin. Median concentrations of nutrients were similar to those in the Irondequoit Creek basin, whereas median concentrations of chloride were lower and those for sulfate were higher. Median concentrations of nutrients at Northrup Creek continued to be higher than those found in the Irondequoit Creek basin, but, because of the improved treatment of phosphorus at the sewage-treatment plant, concentrations of phosphorus, while still higher than at the Irondequoit basin sites, were not as much higher. Median concentrations reported for the three streams tributary to the Genesee River-Honeoye Creek at Honeoye Falls, Oatka Creek at Garbutt, and Black Creek at Churchville-do not represent the entire 1997-99 period and therefore, cannot be reliably compared with median concentrations for the other sites.

\section{Temporal variability}

A statistical test, ANOVA (analysis of variance) and Tukey's Multiple Comparison Test were applied to ranked concentration data to detect statistically significant $(\alpha=0.05)$ differences in median concentrations between the period of record prior to 1997 at each site and those for the 1997-99 period (table 13).

Table 13. Statistically significant differences between mean concentrations of selected constituents for period of record through 1996 and those for 1997-99 at Irondequoit Creek basin sites and Northrup Creek, Monroe County, N.Y.

[L, mean for 1997-99 is significantly lower than that for pre-1997 period; H, mean value for 1997-99 is significantly higher than that for pre-1997 period; ND, no significant difference. Locations are shown in fig. 1.]

\begin{tabular}{lccccc}
\hline \multicolumn{1}{c}{ Constituent or property } & $\begin{array}{c}\text { Blossom } \\
\text { Road }\end{array}$ & $\begin{array}{c}\text { Allen } \\
\text { Creek }\end{array}$ & $\begin{array}{c}\text { East Branch } \\
\text { Allen Creek }\end{array}$ & $\begin{array}{c}\text { Railroad } \\
\text { Mills }\end{array}$ & $\begin{array}{c}\text { Northrup } \\
\text { Creek }\end{array}$ \\
\hline \hline Discharge & -- & -- & ND & ND & H \\
Turbidity & L & L & ND & ND & ND \\
Suspended solids & L & ND & ND & ND & ND \\
Volatile suspended solids & L & ND & ND & ND & ND \\
Ammonia, dissolved & L & L & ND & ND & H \\
Ammonia + organic nitrogen, total & L & L & L & L & L \\
Nitrite + nitrate, total & ND & L & L & ND & L \\
Phosphorus, total & L & L & ND & ND & L \\
Orthophosphate, dissolved & H & ND & ND & H & H \\
Chloride, dissolved & H & ND & ND & H & ND \\
Sulfate, dissolved & L & L & ND & L & L \\
Total significant differences & 9 & 6 & 2 & 4 & 6 \\
\hline
\end{tabular}


The sites with the fewest number of significant differences between the two periods were the two upstream sites in the Irondequoit Creek basin-East Branch Allen Creek and Irondequoit Creek at Railroad Mills. This probably results because land use in their drainage basins has changed little over the last few years. The sites furthest downstream-Allen Creek and Blossom Road-showed the greatest number of significant differences between the two periods.

Median concentrations of ammonia + organic nitrogen for 1997-99 were significantly lower than the period-of-record median at all sites, whereas the median suspended solids concentration for 1997-99 showed a significant difference at only one site, where it was lower than the period-of-record median.

Dissolved chloride showed a significant difference at two of the five sites, and dissolved sulfate showed a significant difference at four of the five sites.

\section{Temporal trends}

The Irondequoit Creek basin has undergone rapid development over the past several years, resulting in an increase in residential land and a corresponding decrease in agricultural land. The effects of these changes on surface-water quality can be evaluated through an analysis of water-quality trends.

A trend, as defined in this report, is a monotonic (overall) change in concentration of a chemical constituent in water samples from a specific sampling site over a specified time period. Trends, regardless of magnitude, were considered statistically significant at $p \leq 0.05$ - where $p$ is the probability that an apparent trend resulted from chance arrangement of the data, rather than an actual change in the trend of the data values. The seasonal Kendall test (Hirsch and others, 1982) is a seasonally adjusted, nonparametric test that looks at all possible seasonal pairs of data values and counts the number of times that the later value is higher (positive difference) or lower (negative difference) than the earlier one. Thus, where the seasons are monthly, each October value is compared with every other October value, November to November etc. If no trend is present in the record, the number of positive and negative differences would tend to be equal. The seasonal Kendall test incorporates comparisons of the ranks of data and thereby minimizes the effects of outliers on trend detection. This test also can be applied to waterquality records with censored data (data reported as less than a specified reporting limit), provided that a single reporting limit is selected for the entire record.

An estimate of the rate of change in the trend slope for the period analyzed was computed according to Sen (1968). The trend slope, expressed as the change in original units (such as milligrams per liter) per year, was computed as the median of all pairwise comparisons (each paired difference is divided by the number of years separating the pair of observations). If more than 10 percent of the data were censored, the magnitude of the trend slope was likely to be inaccurate, and the trend was not reported (Lanfear and Alexander, 1990).

Constituent concentrations typically reflect seasonal variations in biochemical or hydrologic processes or human activities. The seasonal Kendall test accounts for these seasonal differences by allowing comparisons only for the same season of different years.

Variability in constituent concentrations resulting from short-term variations in streamflow can be minimized in trend analysis through regression of concentration as a function of flow by use of a LOWESS (locally weighted scatterplot smoothing) procedure (Cleveland, 1979). The LOWESS procedure is a robust method of fitting a smoothed line to bivariate data. The degree of distance weighting is controlled by adjusting the magnitude of the smoothing factor $(f)$. A smoothing factor of 0.5 is generally used for water-quality data (and was used for this analysis) because it tends to give a good fit to the data without masking the essential features of the relation or producing abrupt changes in slope. This regression produces a residual (flow-adjusted concentration) that is then used in the trend test. Occasionally, this flow adjustment is unsuccessful; if so, the trend is reported as a trend in unadjusted concentrations. The techniques used for addressing the effects of seasonal variation, streamflow variation, missing values, and censored data on trend analysis are discussed in detail in Johnston and Sherwood (1996) and Sherwood (1999).

Generally, the seasonal Kendall trend test produces more reliable results when at least 5 years of data are available (Hirsch and others, 1982). Because these reports represent 3-year periods of data collection, in this case 1997-99, the trend analyses are updated for the entire period of record to include the most recent 3 years of data. 
Table 14. Statistical summary and results of trend tests for selected constituents at four sites in the Irondequoit Creek basin, Monroe County, N.Y., period of record through 1999.

[Units are in milligrams per liter unless otherwise noted, dashes indicate greater than 10-percent censoring. n, number of samples for period of record; Q1, 25th percentile; Q3, 75th percentile; $\mathrm{n}(\mathrm{s})$, number of seasons used in trend test; $\mathrm{n}(\mathrm{t})$, number of samples used in trend analysis; $p$, significance of trend. Bold type indicates trend is statistically significant at $\alpha=0.05 . \mathrm{F}$ (in right column) indicates test was performed on flow-adjusted concentrations, C indicates test was performed on unadjusted concentrations. Locations are shown in fig. 1.]

\begin{tabular}{|c|c|c|c|c|c|c|c|c|c|c|c|c|}
\hline \multirow[b]{2}{*}{ Constituent and site } & \multirow[b]{2}{*}{$\begin{array}{l}\text { Period of } \\
\text { record }\end{array}$} & \multicolumn{5}{|c|}{ Descriptive statistics } & \multicolumn{5}{|c|}{ Trend results } & \multirow[b]{2}{*}{$\begin{array}{l}\text { Trend } \\
\text { code }\end{array}$} \\
\hline & & $\mathrm{n}$ & Mean & Q1 & Median & Q3 & $\mathrm{n}(\mathrm{s})$ & $\mathrm{n}(\mathrm{t})$ & $\begin{array}{l}\text { Units } \\
\text { per year }\end{array}$ & $\begin{array}{l}\text { Percent } \\
\text { per year }\end{array}$ & $p$ & \\
\hline \multicolumn{13}{|l|}{ Ammonia as $\mathrm{N}$, dissolved } \\
\hline Railroad Mills & 1992-99 & 214 & 0.023 & 0.010 & 0.010 & 0.020 & 4 & 31 & -- & -- & 0.719 & $\mathrm{C}$ \\
\hline East Branch Allen Creek & 1991-99 & 246 & .036 & .010 & .020 & .040 & 12 & 81 & -- & -- & .653 & $\mathrm{~F}$ \\
\hline Allen Creek & 1984-99 & 896 & .037 & .010 & .020 & .040 & 12 & 160 & -- & -- & .001 & $\mathbf{F}$ \\
\hline Blossom Road & 1984-99 & 2791 & .044 & .010 & .020 & .030 & 12 & 191 & -- & -- & $<.001$ & $\mathbf{F}$ \\
\hline \multicolumn{13}{|c|}{ Ammonia + organic nitrogen as $\mathrm{N}$, total } \\
\hline Railroad Mills & 1992-99 & 200 & .57 & .34 & .49 & .70 & 4 & 31 & -0.006 & -1.05 & .897 & $\mathrm{~F}$ \\
\hline East Branch Allen Creek & 1991-99 & 250 & .71 & .48 & .68 & .88 & 12 & 81 & -.040 & -5.63 & $<.001$ & $\mathbf{C}$ \\
\hline Allen Creek & 1984-99 & 899 & 1.04 & .73 & 1.00 & 1.30 & 12 & 160 & -.043 & -4.14 & $<.001$ & $\mathbf{F}$ \\
\hline Blossom Road & 1984-99 & 2763 & .95 & .59 & .80 & 1.10 & 12 & 191 & -.049 & -5.18 & $<.001$ & $\mathbf{F}$ \\
\hline \multicolumn{13}{|l|}{ Nitrite + nitrate as $\mathbf{N}$, total } \\
\hline Railroad Mills & 1992-99 & 221 & 1.11 & .91 & 1.10 & 1.30 & 4 & 31 & -.0003 & -.03 & 1.0 & $\mathrm{~F}$ \\
\hline East Branch Allen Creek & 1991-99 & 267 & 1.28 & .58 & 1.20 & 1.80 & 12 & 81 & -.057 & -4.46 & .025 & $\mathbf{F}$ \\
\hline Allen Creek & 1984-99 & 916 & 1.14 & .82 & 1.10 & 1.40 & 12 & 160 & -.019 & -1.67 & $<.001$ & $\mathbf{F}$ \\
\hline Blossom Road & 1984-99 & 2750 & 1.08 & .83 & 1.00 & 1.30 & 12 & 191 & -.002 & -.20 & .550 & $\mathrm{~F}$ \\
\hline \multicolumn{13}{|l|}{ Phosphorus as $\mathrm{P}$, total } \\
\hline Railroad Mills & 1992-99 & 447 & .117 & .040 & .075 & .150 & 12 & 88 & .002 & 1.45 & .278 & $\mathrm{~F}$ \\
\hline East Branch Allen Creek & 1991-99 & 550 & .164 & .065 & .100 & .188 & 12 & 81 & .000 & .11 & .799 & $\mathrm{~F}$ \\
\hline Allen Creek & 1984-99 & 1276 & .132 & .060 & .100 & .160 & 12 & 185 & -.001 & -.48 & .359 & $\mathrm{~F}$ \\
\hline Blossom Road & 1984-99 & 2848 & .150 & .050 & .090 & .160 & 12 & 191 & -.001 & -.60 & .207 & $\mathrm{~F}$ \\
\hline \multicolumn{13}{|c|}{ Orthophosphate as $\mathrm{P}$, dissolved } \\
\hline Railroad Mills & 1992-99 & 452 & .008 & .005 & .007 & .010 & 12 & 88 & .000 & 4.09 & .011 & $\mathbf{F}$ \\
\hline East Branch Allen Creek & 1991-99 & 554 & .030 & .010 & .021 & .032 & 12 & 81 & .000 & .97 & .484 & $\mathrm{~F}$ \\
\hline Allen Creek & 1984-99 & 1282 & .019 & .008 & .017 & .027 & 12 & 185 & .000 & .78 & .132 & $\mathrm{~F}$ \\
\hline Blossom Road & 1984-99 & 2920 & .014 & .007 & .012 & .018 & 12 & 191 & .000 & .21 & .706 & $\mathrm{~F}$ \\
\hline \multicolumn{13}{|l|}{ Chloride, dissolved } \\
\hline Railroad Mills & 1992-99 & 450 & 70 & 60 & 69 & 76 & 12 & 88 & 2.800 & 4.00 & $<0.001$ & $\mathbf{C}$ \\
\hline East Branch Allen Creek & 1991-99 & 551 & 124 & 72 & 99 & 150 & 12 & 81 & -.673 & -0.54 & .852 & $\mathrm{~F}$ \\
\hline Allen Creek & 1984-99 & 1279 & 182 & 100 & 140 & 210 & 12 & 185 & .003 & .00 & $<.001$ & $\mathbf{F}$ \\
\hline Blossom Road & 1984-99 & 2819 & 122 & 96 & 110 & 130 & 12 & 191 & 1.735 & 1.42 & $<.001$ & $\mathbf{F}$ \\
\hline \multicolumn{13}{|l|}{ Sulfate, dissolved } \\
\hline Railroad Mills & 1992-99 & 441 & 172 & 120 & 160 & 220 & 12 & 88 & -2.857 & -1.66 & .423 & $\mathrm{C}$ \\
\hline East Branch Allen Creek & 1991-99 & 545 & 94 & 59 & 84 & 120 & 12 & 81 & -.580 & -.62 & .658 & $\mathrm{~F}$ \\
\hline Allen Creek & 1984-99 & 1189 & 71 & 53 & 68 & 86 & 12 & 185 & -1.235 & -1.74 & $<.001$ & $\mathbf{F}$ \\
\hline Blossom Road & 1984-99 & 2728 & 143 & 110 & 140 & 180 & 12 & 191 & -.549 & -.38 & .029 & $\mathbf{F}$ \\
\hline \multicolumn{13}{|l|}{ Turbidity, NTU } \\
\hline Railroad Mills & 1992-99 & 451 & 37 & 6.6 & 18 & 40 & 12 & 88 & -.001 & -.00 & .606 & $\mathrm{C}$ \\
\hline East Branch Allen Creek & 1991-99 & 549 & 30 & 6.8 & 16 & 33 & 12 & 81 & -.135 & -.45 & 618 & $\mathrm{~F}$ \\
\hline Allen Creek & 1984-99 & 910 & 25 & 5.8 & 16 & 31 & 12 & 158 & -.167 & -.67 & .168 & $\mathrm{C}$ \\
\hline Blossom Road & 1984-99 & 2210 & 33 & 5.7 & 16 & 34 & 6 & 82 & -.033 & -.10 & .750 & $\mathrm{C}$ \\
\hline
\end{tabular}


Table 14. Statistical summary and results of trend tests for selected constituents at four sites in the Irondequoit Creek basin, Monroe County, N.Y., period of record through 1999 (continued)

\begin{tabular}{|c|c|c|c|c|c|c|c|c|c|c|c|c|}
\hline \multirow[b]{2}{*}{ Constituent and site } & \multirow[b]{2}{*}{$\begin{array}{l}\text { Period of } \\
\text { record }\end{array}$} & \multicolumn{5}{|c|}{ Descriptive statistics } & \multicolumn{5}{|c|}{ Trend results } & \multirow[b]{2}{*}{$\begin{array}{l}\text { Trend } \\
\text { code }\end{array}$} \\
\hline & & $\mathrm{n}$ & Mean & Q1 & Median & Q3 & $n(s)$ & $\mathrm{n}(\mathrm{t})$ & $\begin{array}{c}\text { Units } \\
\text { per year }\end{array}$ & $\begin{array}{l}\text { Percent } \\
\text { per year }\end{array}$ & $p$ & \\
\hline \multicolumn{13}{|l|}{ Total suspended solids } \\
\hline Railroad Mills & 1992-99 & 165 & 172 & 76 & 169 & 205 & 4 & 31 & 13.67 & 7.95 & .018 & $\mathbf{F}$ \\
\hline East Branch Allen Creek & $1991-99$ & 174 & 131 & 62 & 100 & 150 & 6 & 46 & -.510 & -.39 & .879 & $\mathrm{~F}$ \\
\hline Allen Creek & 1984-99 & 382 & 139 & 62 & 107 & 182 & 6 & 86 & -.367 & -.26 & .866 & $\mathrm{C}$ \\
\hline Blossom Road & 1984-99 & 902 & 233 & 85 & 142 & 267 & 12 & 168 & -2.743 & -1.18 & -.021 & $\mathbf{F}$ \\
\hline \multicolumn{13}{|c|}{ Volatile suspended solids } \\
\hline Railroad Mills & 1992-99 & 165 & 22 & 10 & 17 & 26 & 4 & 31 & 1.277 & 5.80 & .251 & $\mathrm{~F}$ \\
\hline East Branch Allen Creek & 1991-99 & 173 & 19 & 10 & 15 & 22 & 6 & 46 & -.076 & -.40 & .879 & $\mathrm{~F}$ \\
\hline Allen Creek & 1984-99 & 382 & 19 & 10 & 16 & 24 & 6 & 86 & .360 & 1.90 & .146 & $\mathrm{C}$ \\
\hline Blossom Road & 1984-99 & 897 & 28 & 12 & 19 & 31 & 12 & 168 & -.116 & -.41 & .564 & $\mathrm{~F}$ \\
\hline
\end{tabular}

\section{Irondequoit Creek Basin Sites}

Ten constituents were tested for temporal trends (table 14); results varied with site and constituent. The five nutrients that were tested were ammonia, ammonia + organic nitrogen, nitrite + nitrate, total phosphorus, and orthophosphate. The other five constituents tested for trends were dissolved chloride, dissolved sulfate, turbidity, total suspended solids, and volatile suspended solids.

Nitrogen and phosphorus: Ammonia + organic nitrogen showed significant downward trends at three of the four Irondequoit basin sites-from 4.1 percent per year at Allen Creek to 5.6 percent per year at East Branch Allen Creek. The only site showing no trend in ammonia + organic nitrogen was Railroad Mills. East Branch Allen Creek and Allen Creek also showed downward trends in nitrite + nitrate of 4.5 percent per year and 1.7 percent per year, respectively. Allen Creek and Blossom Road showed downward trends in ammonia, but because more than 20 percent of the data are censored (below the detection limit), magnitudes are not reported. Orthophosphate showed an upward trend of 4.1 percent per year at Railroad Mills.

Dissolved chloride and dissolved sulfate: Railroad Mills, Allen Creek, and Blossom Road showed upward trends in dissolved chloride ranging from greater than 0.001 percent per year at Allen Creek to 4.0 percent per year at Railroad Mills. Trends in chloride are likely to vary among the study periods and are a function of the rate of road salt application during the winter and the amount of impervious area in the drainage basin. Allen Creek and Blossom Road showed downward trends in dissolved sulfate of 1.7 percent per year and 0.4 percent per year, respectively. The source of sulfate to the Irondequoit Creek basin is primarily atmospheric deposition, and, to a lesser extent, dissolution of sulfate bearing rocks. (See table 2.).

Suspended solids and turbidity: None of the Irondequoit sites showed a trend in turbidity. Railroad Mills showed an upward trend of 8.0 percent per year in suspended solids, whereas Blossom Road showed a downward trend of 1.2 percent per year.

\section{Northrup Creek and Genesee River}

Trend analysis of concentrations in Northrup Creek and Genesee River at Charlotte Docks was based on samples collected by the Monroe County Environmental Health Laboratory at Northrup Creek near North Greece and at the Charlotte Pump Station about 1.6 mi downstream of the discontinued National Stream Quality Accounting Network (NASQAN) site 04232006 on the Genesee River. Streamflow data associated with the Genesee River samples were derived from the USGS gaging station about $6 \mathrm{mi}$ upstream of the sampling site.

Four significant trends were noted in constituent concentrations in Northrup Creek. Ammonia + organic nitrogen, total phosphorus, and orthophosphate all showed downward trends, while dissolved sulfate showed an upward trend (table 15). The downward trends in the nutrients, particularly phosphorus (fig. 19), are a result of the improved phosphorus removal capabilities of the wastewater-treatment plant up stream of the sampling site. In August of 1995 the 
Table 15. Statistical summary and results of trend tests for selected chemical constituents at Northrup Creek and Genesee River, Monroe County, N.Y., period of record through 1999.

[Dashes indicate greater than 10-percent censoring. n, number of samples for period of record. Q1; 25th percentile; Q3, 75th percentile; $\mathrm{n}(\mathrm{s})$, number of seasons used in trend test; $\mathrm{n}(\mathrm{t})$, number of samples used in trend analysis; $p$, significance of trend. Units are in milligrams per liter unless otherwise noted. Bold type indicates trend is statistically significant at $\alpha=0.05$. F (in right column) indicates test was performed on flow-adjusted concentrations, $\mathrm{C}$ indicates test was performed on unadjusted concentrations. Locations are shown in fig. 1.]

\begin{tabular}{|c|c|c|c|c|c|c|c|c|c|c|c|}
\hline \multirow[b]{2}{*}{ Site } & \multicolumn{5}{|c|}{ Descriptive statistics } & \multicolumn{6}{|c|}{ Trend results } \\
\hline & $\mathrm{n}$ & Mean & Q1 & Median & Q3 & $n(s)$ & $n(t)$ & $\begin{array}{l}\text { Units } \\
\text { per year }\end{array}$ & $\begin{array}{l}\text { Percent } \\
\text { per year }\end{array}$ & $p$ & $\begin{array}{l}\text { Trend } \\
\text { code }\end{array}$ \\
\hline \multicolumn{12}{|l|}{$\begin{array}{l}\text { Northrup Creek at North Greece, } \\
\text { 1989-99 }\end{array}$} \\
\hline Turbidity, NTU & 782 & 23 & 5.0 & 11 & 27 & 12 & 114 & -0.014 & -.06 & 0.438 & $\mathrm{~F}$ \\
\hline Total suspended solids & 186 & 160 & 71 & 113 & 184 & 6 & 51 & -4.375 & -2.73 & .409 & $\mathrm{C}$ \\
\hline Volatile suspended solids & 185 & 23 & 11 & 17 & 26 & 6 & 51 & -1.000 & -4.35 & .140 & $\mathrm{C}$ \\
\hline Ammonia as $\mathrm{N}$, dissolved & 775 & .120 & .020 & .040 & .140 & 12 & 114 & -.002 & -1.33 & .216 & $\mathrm{~F}$ \\
\hline Ammonia + organic nitrogen as $\mathrm{N}$, total & 779 & 1.00 & .72 & .89 & 1.10 & 12 & 114 & -.033 & -3.29 & $<.001$ & $\mathbf{F}$ \\
\hline Nitrite + nitrate as $\mathrm{N}$, total & 778 & 1.52 & 1.10 & 1.40 & 1.70 & 12 & 114 & -.005 & -.35 & .521 & $\mathrm{~F}$ \\
\hline Phosphorus as P, total & 779 & .365 & .160 & .260 & .520 & 12 & 114 & -.012 & -3.40 & .012 & $\mathbf{F}$ \\
\hline Orthophosphate as $\mathbf{P}$, dissolved & 788 & .205 & .056 & .155 & .300 & 12 & 114 & -.011 & -5.51 & $<.001$ & $\mathbf{F}$ \\
\hline Chloride, dissolved & 789 & 84 & 57 & 74 & 100 & 12 & 114 & 1.333 & 1.59 & .250 & $\mathrm{~F}$ \\
\hline Sulfate, dissolved & 788 & 52 & 41 & 50 & 60 & 12 & 114 & .962 & 1.85 & .050 & $\mathbf{F}$ \\
\hline \multicolumn{12}{|l|}{$\begin{array}{l}\text { Genesee River at Charlotte Pump } \\
\text { Station, 1990-99 }\end{array}$} \\
\hline Turbidity, NTU & 1949 & 36 & 6.2 & 14 & 38 & 12 & 120 & 0.530 & 1.47 & 0.093 & $\mathrm{~F}$ \\
\hline Total suspended solids & 532 & 141 & 69 & 106 & 184 & 12 & 81 & 1.841 & 1.31 & .321 & $\mathrm{~F}$ \\
\hline Volatile suspended solids & 527 & 12 & 6.0 & 9.0 & 12 & 12 & 81 & -.086 & -.71 & .498 & $\mathrm{~F}$ \\
\hline Ammonia as $\mathrm{N}$, dissolved & 1938 & .132 & .070 & .100 & .160 & 12 & 120 & -.003 & -2.60 & .156 & $\mathrm{~F}$ \\
\hline Ammonia + organic nitrogen as $\mathrm{N}$, total & 1947 & .68 & .50 & .62 & .78 & 12 & 120 & -.042 & -6.11 & $<.001$ & $\mathbf{F}$ \\
\hline Nitrite + nitrate as $\mathrm{N}$, total & 1969 & 1.04 & .70 & .90 & 1.20 & 12 & 120 & -.005 & -.51 & .454 & $\mathrm{~F}$ \\
\hline Phosphorus as P, total & 1971 & .093 & .050 & .070 & .100 & 12 & 120 & .002 & 1.74 & .021 & $\mathbf{F}$ \\
\hline Orthophosphate as $\mathbf{P}$, dissolved & 1979 & .022 & .013 & .018 & .026 & 12 & 120 & .001 & 6.65 & $<.001$ & $\mathbf{F}$ \\
\hline Chloride, dissolved & 1981 & 62 & 40 & 52 & 74 & 12 & 120 & -.043 & -.07 & $<.001$ & $\mathbf{F}$ \\
\hline Sulfate, dissolved & 1973 & 71 & 48 & 71 & 91 & 12 & 120 & -.631 & -.89 & .104 & $\mathrm{~F}$ \\
\hline
\end{tabular}

Spencerport treatment plant began adding iron salts to improve the removal of phosphorus from treatmentplant effluent (Sherwood, 1999).

Four significant trends were also noted in constituent concentrations in the Genesee River. Total phosphorus and orthophosphate showed significant upward trends (1.74 percent per year and 6.65 percent per year, respectively), whereas ammonia + organic nitrogen and dissolved chloride showed significant downward trends of 6.11 percent per year and 0.07 percent per year, respectively. Trends noted in this report should not be compared with trends published in previous reports for the Genesee River. Because those trends were based on data collected at a different sampling location (the discontinued NASQAN site), at different sampling frequencies, and by different sampling methods.

\section{Chemical Loads and Yields}

Chemical load calculations provide an estimate of the amount (mass) of a particular constituent moving past a given point (gaging station) or into a receiving body of water. Chemical loads presented in this report were calculated by the ESTIMATOR program (Cohn and others, 1992), which uses multivariate linear regression to develop a quantitative relation between periodic constituent concentrations and daily streamflows to estimate daily constituent loads, and the minimum-variance unbiased estimator (MVUE) procedure to correct for log-retransformation bias (Cohn and others, 1989). The ESTIMATOR program also uses an adjusted maximum likelihood estimator (AMLE) of the moments of lognormal populations to estimate values for censored data. 

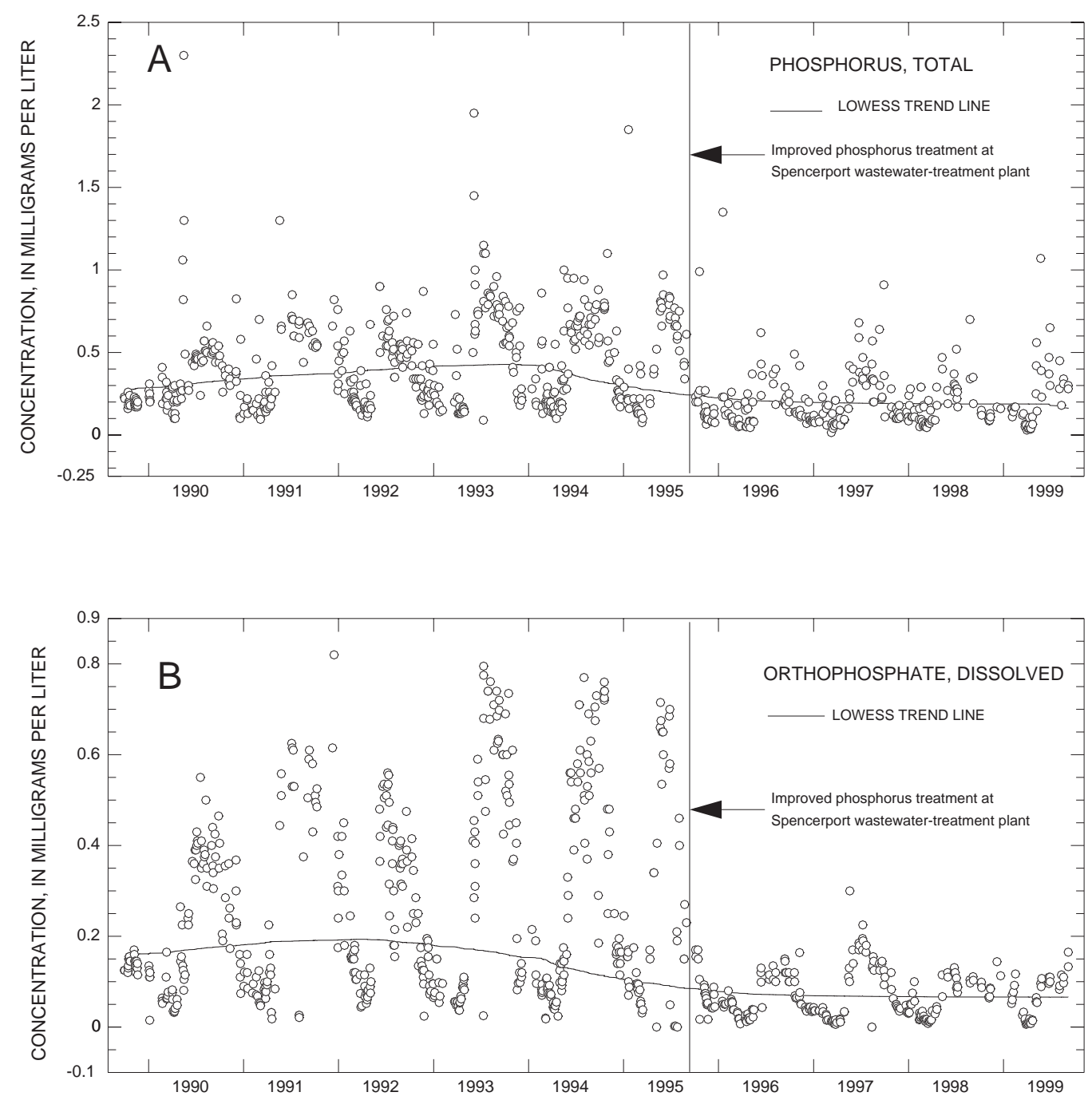

Figure 19. Concentrations of (A) total phosphorus and (B) orthophosphate along with Locally Weighted Scatterplot Smooth (LOWESS) trendlines, before and after implementation of improved treatment for phosphorus at the Spencerport wastewater-treatment plant, at Northrup Creek at North Greece, Monroe County, N.Y., for period of record through 1999.

The ESTIMATOR program estimates constituent concentration from equation 1 , where streamflow, time, and seasonal indicators (sine and cosine transformations of time) serve as explanatory variables to remove the effects of seasonality in the data. It then computes daily loads (eq. 2), applies the MVUE bias correction to those daily estimates, and finally sums those estimates to monthly and annual totals.

$$
\begin{aligned}
\ln [C]= & \beta_{0}+\beta_{1} \ln [Q / \tilde{Q}]+\beta_{2}\{\ln [Q / \tilde{Q}]\}^{2}+ \\
& \beta_{3}[T / \tilde{T}]+\beta_{4}\left[T / \tilde{T}^{2}\right]+\beta_{5} \sin [2 \pi T]+ \\
& \beta_{6} \cos [2 \pi T]+\varepsilon
\end{aligned}
$$

where

$$
\begin{aligned}
& C=\text { constituent concentration, in milligrams } \\
& \text { per liter } \\
& \text { Q = discharge at time of sample collection, in } \\
& \mathrm{T}=\text { time, in years } \\
& \varepsilon=\text { error (assumed to be independent and } \\
& \text { normally distributed with a mean and } \\
& \text { variance of zero) } \\
& \beta \text { 's = parameters of the equation that must be } \\
& \text { estimated from the data, and } \\
& \tilde{\mathrm{Q}}, \tilde{\mathrm{T}}=\text { centering variables that simplify the }
\end{aligned}
$$


The corresponding load $L$ is given by

$$
\begin{aligned}
& L=K Q \exp \left(\beta_{0}+\beta_{1} \ln [Q / \tilde{Q}]+\beta_{2}\{\ln [Q / \tilde{Q}]\}^{2}+\right. \\
& \beta_{3}[T / \tilde{T}]+\beta_{4}\left[T / \tilde{T}^{2}+\beta_{5} \sin [2 \pi T]+\right. \\
& \left.\beta_{6} \cos [2 \pi T]+\varepsilon\right) \\
& \text { where } \\
& K=\text { conversion factor, } \\
& Q=\text { daily mean discharge, in cubic feet per } \\
& \quad \text { second, and all other variables are as defined } \\
& \quad \text { for equation } 1 .
\end{aligned}
$$

The precision of the estimated loads can be described in terms of a confidence interval that is based on the estimated mean and the standard error of prediction. At the 95-percent confidence interval $(\alpha=0.05)$, the confidence limits are the estimated load \pm 1.96 times the standard error of prediction. The value 1.96 is from a statistical table for a Student's tdistribution at the $\alpha / 2$ quantile with a large number of samples (more than 250). If, for example, the monthly load estimated for chloride was 145 tons, and the standard error of prediction was 12 tons, the approximate 95-percent confidence limits would be:

$145 \pm(1.96 \times 12)=121.5$ to 168.5 tons.

The wider the confidence limits, the greater the uncertainty and, hence, the less reliable the load estimates. A more detailed explanation of the MVUE method is given in Cohn and others (1992).

Knowledge of trends in the loads of chemical constituents carried by streams and their tributaries is important in assessing the effectiveness of management practices already in use and in evaluating the effect of land-use changes within the watershed on receiving bodies of water.

Some of the parameter estimates (coefficients) for the terms of the equation used to calculate concentrations (eq. 1) can be directly related to basin characteristics or to physical process. For example, $\beta_{1}$, which corresponds to the linear dependence of concentration on streamflow, may depend on the source of the constituent-negative values indicate a dilution effect, suggesting point sources; near-zero values imply no effect from dilution, as is characteristic of some dissolved constituents; and positive values are generally indicative of sedimentrelated nonpoint sources. The value of $\beta_{3}$ corresponds to the magnitude of the log-linear component of the upward or downward time trends in constituent load. $\mathrm{R}^{2}$ (coefficient of variation) of the concentration is the variability explained by the equation for the logarithm of concentration and $\mathrm{R}^{2}$ load is the variability explained by the equation for the logarithm of load. The dependence of concentration on flow $\left(\beta_{1}\right)$, the direction and magnitude of trends in loads $\left(\beta_{3}\right)$, and coefficients of variation $\left(\mathrm{R}^{2}\right)$ for concentration and load are summarized in table 16.

Flow related coefficients ( $\beta_{1}$ values) for total suspended solids and volatile suspended solids at most sites indicate a statistically significant positive dependence on flow, implying a probable nonpoint source for these constituents (table 16). The lower $\beta_{1}$ coefficients for these constituents at Irondequoit Creek at Railroad Mills, East Branch Allen Creek, and Northrup Creek indicate a mix of point and nonpoint sources at these sites. The $\beta_{1}$ coefficients for dissolved chloride and dissolved sulfate at all sites indicate a significant negative dependence on flow, which implies the strong probability of point sources for these constituents. The $\beta_{1}$ coefficients for nutrients suggest a combination of point and nonpoint sources at some sites, whereas ammonia showed a strong negative dependence on flow at Northrup Creek and Black Creek at Churchville implying point sources at these sites for this constituent. The $\beta_{1}$ coefficient for total phosphorus at Irondequoit Creek at Railroad Mills showed a significant indication of a nonpoint source for that constituent.

Irondequoit Creek at Railroad Mills and Northrup Creek show significant upward trends in loads of total and volatile suspended solids for water years 1997-99, whereas Oatka Creek at Garbutt showed a significant downward trend in loads of total and volatile suspended solids (-35.1 percent and -51.4 percent, respectively) for the 1998-99 water years (period of record). The large upward trends in these constituents at Irondequoit Creek at Railroad Mills and Northrup Creek are related to the peak-of-record high flow of January 8, 1998, which was fairly close to the end of the 1997-99 period, whereas the large downward trend at Oatka Creek at Garbutt reflects that stormflow's occurrence near the beginning of that site's period of record (1998-99). The direction and magnitude of trends in loads of all nutrients except nitrite + nitrate were mixed; nitrite + nitrate showed decreasing trends at all sites; these ranged from 4.3 percent per year at Northrup Creek to 39 percent per year at Black Creek at Churchville. Orthophosphate was the nutrient with increasing trends at the greatest number of sites; these ranged from 1.4 percent per year at East Branch Allen Creek to 24 percent per year at Railroad Mills, but it 
Table 16. Equation parameter estimates showing linear dependence of concentration on flow $\left(\beta_{1}\right)$ and magnitude $\left(\beta_{3}\right)$, in percent per year, of estimated trends in loads for selected constituents, and $R^{2}$ values for concentrations and loads at four sites in the Irondequoit Creek basin, Genesee River, and four sites in western Monroe County, N.Y., 1997-99.

[Bold type indicates figure is statistically significant at $\alpha=0.05$. Negative value for parameter $\beta_{1}$ indicates dilution effect; positive or negative value for parameter $\beta_{3}$ indicates upward or downward trend, respectively. Dashes indicate no/insufficient data. Locations are shown in fig. 1.]

\begin{tabular}{|c|c|c|c|c|c|c|c|c|c|c|}
\hline \multirow[b]{2}{*}{ Site } & \multirow[b]{2}{*}{$\begin{array}{l}\text { Equation } 1 \\
\text { parameter }^{1}\end{array}$} & \multicolumn{9}{|c|}{ Constituent } \\
\hline & & $\begin{array}{l}\text { Total } \\
\text { sus- } \\
\text { pended } \\
\text { solids }\end{array}$ & $\begin{array}{l}\text { Volatile } \\
\text { sus- } \\
\text { pended } \\
\text { solids } \\
\end{array}$ & $\begin{array}{l}\text { Ammonia } \\
\text { as N, } \\
\text { dissolved }\end{array}$ & $\begin{array}{c}\text { Ammonia } \\
\text { + organic } \\
\text { nitrogen } \\
\text { as N, total }\end{array}$ & $\begin{array}{c}\text { Nitrite } \\
+ \\
\text { nitrate } \\
\text { as } \mathrm{N} \text {, total } \\
\end{array}$ & $\begin{array}{l}\text { Phos- } \\
\text { phorus } \\
\text { as } P \text {, total }\end{array}$ & $\begin{array}{l}\text { Ortho- } \\
\text { phosphate } \\
\text { as P, } \\
\text { dissolved }\end{array}$ & $\begin{array}{l}\text { Chloride, } \\
\text { dissolved }\end{array}$ & $\begin{array}{c}\text { Sulfate, } \\
\text { dissolved }\end{array}$ \\
\hline \multirow{4}{*}{$\begin{array}{l}\text { Irondequoit Creek } \\
\text { at Railroad Mills }\end{array}$} & $\beta_{1}$ & 0.249 & 0.021 & 0.516 & 0.290 & -0.164 & 0.832 & 0.475 & -0.175 & -0.324 \\
\hline & $\beta_{3}$ & 89.1 & 87.0 & -20.0 & -4.33 & -8.92 & 12.1 & 24.0 & .56 & -.69 \\
\hline & $\mathrm{R}^{2}$ Conc & 35.3 & 33.5 & 61.9 & 25.6 & 53.3 & 39.8 & 68.5 & 38.0 & 74.6 \\
\hline & $\mathrm{R}^{2}$ Load & 60.6 & 60.2 & 85.9 & 78.8 & 93.9 & 70.8 & 89.1 & 91.5 & 80.7 \\
\hline \multirow{4}{*}{$\begin{array}{l}\text { East Branch } \\
\text { Allen Creek at } \\
\text { Pittsford }\end{array}$} & $\beta_{1}$ & .442 & .244 & -.032 & .151 & .205 & .358 & .396 & - .099 & -.260 \\
\hline & $\beta_{3}$ & 21.9 & 26.4 & 10.3 & -4.36 & -22.5 & - 10.4 & 1.38 & -6.64 & -2.58 \\
\hline & $\mathrm{R}^{2}$ Conc & 44.5 & 32.5 & 32.1 & 33.7 & 75.5 & 64.7 & 66.7 & 76.0 & 62.5 \\
\hline & $\mathrm{R}^{2}$ Load & 86.1 & 85.1 & 77.3 & 95.8 & 96.4 & 92.6 & 90.1 & 94.0 & 87.1 \\
\hline \multirow{4}{*}{$\begin{array}{l}\text { Allen Creek near } \\
\text { Rochester }\end{array}$} & $\beta_{1}$ & .683 & .436 & .021 & .048 & .008 & .332 & .177 & -.189 & - . 186 \\
\hline & $\beta_{3}$ & 18.2 & 3.07 & -6.27 & -21.7 & -11.5 & -3.43 & 3.36 & - 7.81 & 3.41 \\
\hline & $\mathrm{R}^{2}$ Conc & 60.0 & 51.5 & 23.8 & 28.8 & 46.1 & 54.6 & 77.0 & 66.1 & 57.7 \\
\hline & $\mathrm{R}^{2}$ Load & 87.7 & 88.7 & 80.6 & 88.0 & 94.8 & 86.8 & 91.7 & 88.3 & 95.0 \\
\hline \multirow{4}{*}{$\begin{array}{l}\text { Irondequoit Creek } \\
\text { at Blossom Road }\end{array}$} & $\beta_{1}$ & 1.45 & .940 & .387 & .410 & - .009 & -.001 & .265 & - .183 & - .307 \\
\hline & $\beta_{3}$ & -5.34 & -6.11 & 17.8 & -12.1 & -7.73 & 9.00 & 21.3 & -2.92 & .89 \\
\hline & $\mathrm{R}^{2}$ Conc & 46.2 & 40.3 & 33.5 & 32.8 & 63.4 & 53.0 & 66.5 & 52.6 & 59.1 \\
\hline & $\mathrm{R}^{2}$ Load & 73.9 & 71.7 & 76.0 & 86.0 & 96.8 & 81.8 & 89.3 & 93.4 & 75.6 \\
\hline \multirow{4}{*}{$\begin{array}{l}\text { Northrup Creek at } \\
\text { North Greece }\end{array}$} & $\beta_{1}$ & .323 & .164 & -.817 & .038 & -.211 & .179 & -.134 & -.111 & -.091 \\
\hline & $\beta_{3}$ & 65.6 & 52.1 & -11.3 & -8.85 & -4.26 & -.520 & 4.13 & -5.34 & 10.1 \\
\hline & $\mathrm{R}^{2}$ Conc & 41.8 & 41.9 & 80.0 & 28.2 & 46.9 & 61.2 & 85.6 & 77.4 & 46.5 \\
\hline & $\mathrm{R}^{2}$ Load & 74.5 & 79.6 & 88.6 & 85.8 & 90.6 & 77.1 & 86.2 & 94.9 & 93.5 \\
\hline \multirow{4}{*}{$\begin{array}{l}\text { Genesee River at } \\
\text { Charlotte Pump } \\
\text { Station }\end{array}$} & $\beta_{1}$ & 1.41 & 1.28 & -.424 & -.031 & .052 & .477 & -.019 & -.213 & -.292 \\
\hline & $\beta_{3}$ & -3.35 & -8.06 & - 11.8 & -4.31 & -5.36 & 4.89 & 3.47 & -1.30 & .190 \\
\hline & $\mathrm{R}^{2}$ Conc & 50.3 & 36.1 & 61.8 & 10.0 & 53.6 & 50.2 & 46.9 & 56.1 & 81.3 \\
\hline & $\mathrm{R}^{2}$ Load & 78.8 & 66.0 & 73.6 & 90.6 & 96.1 & 92.0 & 83.9 & 94.9 & 94.9 \\
\hline \multirow{4}{*}{$\begin{array}{l}\text { Black Creek at } \\
\text { Churchville }\end{array}$} & $\beta_{1}$ & -- & -- & -.806 & .082 & .308 & .275 & .140 & -.132 & -.232 \\
\hline & $\beta_{3}$ & -- & -- & 81.1 & 11.4 & - 39.1 & 53.6 & -26.3 & .89 & 18.0 \\
\hline & $\mathrm{R}^{2}$ Conc & -- & -- & 43.6 & 21.4 & 71.8 & 51.1 & 64.6 & 63.9 & 79.9 \\
\hline & $\mathrm{R}^{2}$ Load & -- & -- & 64.7 & 95.3 & 95.3 & 92.7 & 92.0 & 99.0 & 94.7 \\
\hline \multirow{4}{*}{$\begin{array}{l}\text { Oatka Creek at } \\
\text { Garbutt }\end{array}$} & $\beta_{1}$ & 1.206 & .706 & .141 & .389 & .120 & .358 & .862 & - .140 & -.402 \\
\hline & $\beta_{3}$ & -35.1 & -51.4 & 20.6 & 4.53 & -18.5 & - 10.4 & 22.1 & -13.5 & -7.51 \\
\hline & $\mathrm{R}^{2}$ Conc & 61.5 & 54.3 & 56.3 & 34.3 & 87.1 & 64.7 & 62.9 & 67.8 & 91.2 \\
\hline & $\mathrm{R}^{2}$ Load & 89.4 & 86.2 & 89.9 & 92.1 & 99.2 & 92.6 & 92.5 & 99.0 & 87.5 \\
\hline \multirow{4}{*}{$\begin{array}{l}\text { Honeoye Creek at } \\
\text { Honeoye Falls }\end{array}$} & $\beta_{1}$ & -- & -- & -.012 & .071 & .238 & .310 & .138 & -.092 & - .078 \\
\hline & $\beta_{3}$ & -- & -- & 80.2 & .23 & -12.9 & 3.72 & -41.3 & 15.1 & 6.80 \\
\hline & $\mathrm{R}^{2}$ Conc & -- & -- & 30.8 & 17.3 & 59.3 & 48.0 & 65.3 & 68.6 & 55.6 \\
\hline & $\mathrm{R}^{2}$ Load & -- & -- & 92.7 & 96.8 & 91.0 & 96.9 & 96.7 & 99.3 & 98.1 \\
\hline
\end{tabular}

$1 \beta_{1}$ estimates were retransformed from $\log$ units as $\left(e^{\beta 1}-1\right) ; \beta_{3}$ estimates were retransformed from log units as $100\left(e^{\beta 3}-1\right)$. 
showed a decreasing trend of 41 percent per year at Honeoye Creek at Honeoye Falls. The greatest increasing trend in total phosphorus (54 percent per year) was at Black Creek. Trends in constituent loads for Black Creek, Oatka Creek, and Honeoye Creek should be interpreted with caution however, because of the relatively short (2 year) period of data collection. Reliable trend analysis generally requires at least 5 years of data.

The loads of most constituents generally are greatest during the spring (February through May), when snowmelt and spring rains cause high runoff. The loads of constituents that were analyzed for total concentration (suspended and dissolved), such as ammonia + organic nitrogen, nitrite + nitrate, and total phosphorus, were greatest at these times. In contrast, the concentrations of dissolved constituents, such as orthophosphate, ammonia nitrogen, chloride, and sulfate, vary with flow to a far lesser degree and usually are diluted by high flows; however, the large volumes of flow during spring generally are enough to produce large loads of these constituents despite dilution.

\section{Irondequoit Creek Basin Sites}

Total annual loads entering Irondequoit Bay from the Irondequoit Creek basin are estimated by multiplying the calculated loads for Irondequoit Creek at Empire Boulevard (Coon, 2000) by 1.10 to account for the additional drainage area between Empire
Boulevard and the bay. Residence times of constituents in the bay range from several months to several years (Bubeck and Burton, 1989); thus, a minor change in load of some of the conservative constituents could have a major effect on water quality of the bay because those constituents tend to accumulate in the sediments of the bay, where they are subject to resuspension and release when these sediments are disturbed.

Annual loads of chemical constituents transported to Irondequoit Bay by Irondequoit Creek were consistent with annual runoff (table 17) - greatest annual loads occurred during 1998, when the runoff (15.5 in.) was highest. The percentage of annual loads transported during the spring snowmelt period (February through May), when runoff is usually highest, were lower than would be expected for 1997 98. This was because water years 1997 and 1998 had several months outside the usual high runoff period when precipitation exceeded normal by a considerable amount (table 1). Water year 1997 had 4 months outside the February through May period in which total precipitation exceeded normal by 63 percent, and water year 1998 had 5 months in which total precipitation exceeded normal by 97 percent. Water year 1999 was more typical in that the greatest loads of most constituents were transported during the spring snowmelt and runoff period. The percentage of annual loads of nitrite + nitrate carried during the spring snowmelt and runoff period was consistent among all 3 years, regardless of differences in runoff.

Table 17. Annual loads of selected constituents transported by Irondequoit Creek to Irondequoit Bay, Monroe County, N.Y., water years 1997-99, and percentage of total annual load transported from February through May.

[Annual loads are in tons per year.]

\begin{tabular}{|c|c|c|c|c|c|c|c|c|c|c|}
\hline \multirow[b]{2}{*}{$\begin{array}{c}\text { Water year } \\
\text { or } \\
\text { period }\end{array}$} & \multicolumn{9}{|c|}{ Constituent } & \multirow[b]{2}{*}{$\begin{array}{c}\text { Annual } \\
\text { runoff } \\
\text { (inches) }\end{array}$} \\
\hline & $\begin{array}{l}\text { Total } \\
\text { sus- } \\
\text { pended } \\
\text { solids }\end{array}$ & $\begin{array}{l}\text { Volatile } \\
\text { suspended } \\
\text { solids }\end{array}$ & $\begin{array}{l}\text { Ammonia, } \\
\text { dissolved }\end{array}$ & $\begin{array}{l}\text { Ammonia } \\
\text { + organic } \\
\text { nitrogen, } \\
\text { total }\end{array}$ & $\begin{array}{c}\text { Nitrite + } \\
\text { nitrate, } \\
\text { total }\end{array}$ & $\begin{array}{c}\text { Phos- } \\
\text { phorus, } \\
\text { total }\end{array}$ & $\begin{array}{l}\text { Ortho } \\
\text { phos- } \\
\text { phate, } \\
\text { dissolved }\end{array}$ & $\begin{array}{l}\text { Chloride } \\
\text { dissolved }\end{array}$ & $\begin{array}{l}\text { Sulfate } \\
\text { dissolved }\end{array}$ & \\
\hline \multicolumn{11}{|c|}{ A. Annual loads (multiplied by 1.10 to account for drainage area between Empire Boulevard and mouth) } \\
\hline 1997 & 11,600 & 1,660 & 6.18 & 96.8 & 196 & 12.8 & 2.34 & 21,600 & 16,700 & 13.0 \\
\hline 1998 & 20,800 & 2,990 & 6.79 & 107 & 175 & 24.3 & 3.76 & 23,600 & 18,500 & 15.5 \\
\hline 1998 & 14,300 & 2,010 & 5.92 & 71.8 & 153 & 20.2 & 2.39 & 18,200 & 15,600 & 10.7 \\
\hline 97-99 (Mean) & 15,600 & 2,220 & 6.30 & 91.9 & 175 & 19.1 & 2.83 & 21,100 & 16,900 & 13.0 \\
\hline \multicolumn{11}{|c|}{ B. Percentage of total annual loads transported from February through May (spring snowmelt and runoff period) } \\
\hline 1997 & 24 & 22 & 36 & 38 & 49 & 30 & 22 & 44 & 36 & 40 \\
\hline 1998 & 19 & 17 & 30 & 34 & 49 & 22 & 18 & 42 & 35 & 37 \\
\hline 1999 & 40 & 32 & 49 & 57 & 48 & 48 & 37 & 57 & 45 & 56 \\
\hline 97-99 (Mean) & 28 & 24 & 38 & 43 & 49 & 33 & 26 & 48 & 39 & 44 \\
\hline
\end{tabular}



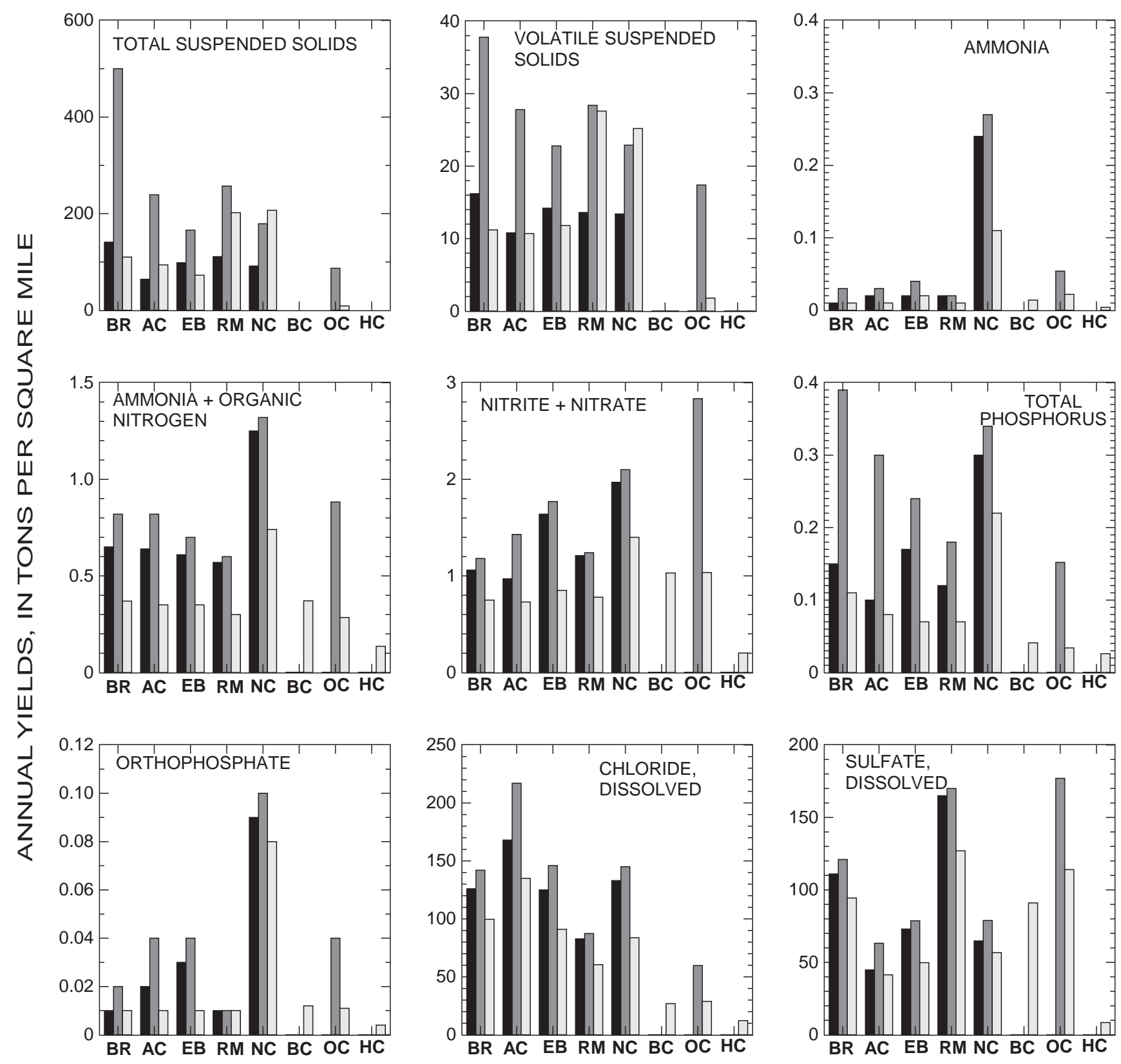

EXPLANATION

\begin{tabular}{ll} 
& BR Irondequoit Creek at Blossom Road \\
& AC Allen Creek near Rochester \\
1997 & EB East Branch Allen Creek at Pittsford \\
$\square 1998$ & RM Irondequoit Creek at Railroad Mills \\
\hline 1999 & NC Northrup Creek at North Greece \\
& BC Black Creek at Churchville \\
& OC Oatka Creek at Garbutt \\
& HC Honeoye Creek at Honeoye Falls
\end{tabular}

Figure 20. Annual yield of selected constituents at four sites in the Irondequoit Creek basin (Irondequoit Creek at Blossom Road, Allen Creek, East Branch Allen Creek, and Irondequoit Creek at Railroad Mills) and four western sites (Northrup Creek, Black Creek, Oatka Creek, Honeoye Creek) in Monroe County, N.Y., water years 199799. (Locations are shown in fig. 1.) 
Yields (load per unit area) are more helpful than loads in basin-to-basin comparisons. For example, one basin may have a greater total load than another simply because it has a larger area; yet, it may have a smaller yield than the other basin. Thus, the interpretation as to the difference in the yields from each basin might be quite different than for differences in loads. Annual yields (in tons per square mile of basin above the measuring point) for the four sites representing the Irondequoit Creek subbasins (Irondequoit Creek at Blossom Road, Allen Creek, East Branch Allen Creek, and Irondequoit Creek at Railroad Mills), and four sites in western Monroe County (Northrup Creek, Black Creek, Oatka Creek, Honeoye Creek), are summarized in figure 20. Among the four Irondequoit Creek basin sites, mean annual yields of nutrients for 1997-99 generally were comparable to those of previous report periods and from site to site. Mean annual 1997-99 yields of total phosphorus and orthophosphate at Allen Creek were higher than those of the previous periods. Mean annual yields of all constituents at East Branch Allen Creek have decreased steadily since the first reporting period (1991-93) (table 18); these decreases in yield result from the construction of a stormwater-detention basin in the summer of 1995 on East Branch Allen Creek about 1.1 mi upstream of the monitoring site. The stormwater stored in the pond during high flows is released slowly through East Branch Allen Creek and used for irrigation downstream during the summer.

Table 18. Mean annual yields of selected constituents at four sites in the Irondequoit Creek basin and four western sites in Monroe County, N.Y., for indicated water years.

[All values are in tons per square mile. Dashes indicate no/insufficient data: Locations are shown in fig. 1.]

\begin{tabular}{|c|c|c|c|c|c|c|c|c|c|c|}
\hline Water year & $\begin{array}{l}\text { Total } \\
\text { suspended } \\
\text { solids }\end{array}$ & $\begin{array}{l}\text { Volatile } \\
\text { suspended } \\
\text { solids }\end{array}$ & $\begin{array}{l}\text { Ammonia, } \\
\text { dissolved }\end{array}$ & $\begin{array}{c}\text { Ammonia + } \\
\text { organic } \\
\text { nitrogen, } \\
\text { total }\end{array}$ & $\begin{array}{c}\text { Nitrite + } \\
\text { nitrate, } \\
\text { total }\end{array}$ & $\begin{array}{l}\text { Phos- } \\
\text { phorus, } \\
\text { total }\end{array}$ & $\begin{array}{l}\text { Ortho- } \\
\text { phosphate, } \\
\text { dissolved }\end{array}$ & $\begin{array}{l}\text { Chloride, } \\
\text { dissolved }\end{array}$ & $\begin{array}{c}\text { Sulfate, } \\
\text { dissolved }\end{array}$ & $\begin{array}{l}\text { Runoff, } \\
\text { in } \\
\text { inches }\end{array}$ \\
\hline \multicolumn{11}{|c|}{ Irondequoit Creek at Blossom Road } \\
\hline 1984-88 & 170 & 19.0 & 0.038 & 1.13 & 1.15 & 0.138 & 0.015 & 99.7 & 112 & 12.67 \\
\hline $1989-93$ & 277 & 35.1 & .030 & 1.18 & 1.09 & .240 & .010 & 115 & 111 & 13.88 \\
\hline $1994-96$ & 143 & 17.7 & .013 & .64 & .91 & .140 & .011 & 114 & 106 & 11.54 \\
\hline $1997-99$ & 250 & 21.7 & .017 & .61 & 1.00 & .220 & .013 & 123 & 109 & 13.27 \\
\hline \multicolumn{11}{|c|}{ Allen Creek near Rochester } \\
\hline $1984-88$ & 143 & 17.4 & .044 & 1.26 & 1.30 & .146 & .021 & 161 & 72.1 & 13.86 \\
\hline 1989-93 & 117 & 19.0 & .040 & 1.06 & 1.14 & .140 & .020 & 173 & 60.4 & 13.64 \\
\hline $1994-96$ & 142 & 17.9 & .018 & .67 & .91 & .110 & .018 & 178 & 51.4 & 11.12 \\
\hline $1997-99$ & 132 & 16.4 & .020 & .60 & 1.04 & .160 & .023 & 173 & 49.8 & 13.26 \\
\hline \multicolumn{11}{|c|}{ East Branch Allen Creek at Pittsford } \\
\hline 1991-93 & 199 & 28.5 & .050 & 1.34 & 2.45 & .260 & .030 & 136 & 102 & 19.62 \\
\hline $1994-96$ & 164 & 21.3 & .042 & 1.05 & 1.71 & .170 & .033 & 143 & 97.0 & 15.84 \\
\hline 1997-99 & 112 & 16.3 & .027 & .55 & 1.42 & .160 & .027 & 121 & 67.1 & 17.45 \\
\hline \multicolumn{11}{|c|}{ Irondequoit Creek at Railroad Mills } \\
\hline $1992-93$ & 124 & 16.9 & .010 & .62 & .73 & .100 & .010 & 42.3 & 124 & 15.68 \\
\hline $1994-96$ & 173 & 20.3 & .010 & .55 & .99 & .100 & .007 & 62.8 & 255 & 12.02 \\
\hline 1997-99 & 190 & 23.2 & .017 & .49 & 1.08 & .123 & .010 & 76.9 & 154 & 13.77 \\
\hline \multicolumn{11}{|c|}{ Northrup Creek at North Greece } \\
\hline 1990-93 & 240 & 30.8 & .160 & 1.37 & 1.55 & .380 & .180 & 84.1 & 48.3 & 15.09 \\
\hline $1994-96$ & 246 & 29.6 & .210 & 1.05 & 1.57 & .320 & .130 & 107 & 54.6 & 14.22 \\
\hline $1997-99$ & 159 & 20.5 & .207 & 1.10 & 1.82 & .290 & .090 & 121 & 66.8 & 18.54 \\
\hline \multicolumn{11}{|c|}{ Black Creek at Churchville } \\
\hline 1999 & -- & -- & .014 & .37 & 1.03 & .041 & .012 & 27.0 & 91.0 & -- \\
\hline \multicolumn{11}{|c|}{ Oatka Creek at Garbutt } \\
\hline 1998-99 & 48.0 & 9.6 & .038 & .58 & 1.94 & .026 & .001 & 44.3 & 116 & -- \\
\hline \multicolumn{11}{|c|}{ Honeoye Creek at Honeoye Falls } \\
\hline 1999 & -- & -- & .004 & .14 & .20 & .026 & .004 & 12.3 & 8.54 & -- \\
\hline
\end{tabular}


Table 19. Median concentrations of selected constituents during the non-navigation season at East Branch Allen Creek before and after construction of the detention pond at Jefferson Road, Monroe County, N.Y.

[Units are milligrams per liter, unless otherwise noted. Bold type indicates difference is significant at $\alpha=0.05$. Location is shown in fig. 1.]

\begin{tabular}{lcc}
\hline \multicolumn{1}{c}{ Constituent or property } & Before & After \\
\hline \hline Flow (cubic feet per second) & 15.0 & 14.0 \\
Turbidity (nephlometric turbidity units) & 13.5 & 10.0 \\
Total suspended solids & $\mathbf{1 3 6}$ & $\mathbf{7 6 . 0}$ \\
Volatile suspended solids & 20.0 & 14.0 \\
Ammonia, dissolved & 0.030 & 0.020 \\
Ammonia + organic nitrogen, total & $\mathbf{0 . 8 0}$ & $\mathbf{0 . 6 0}$ \\
Nitrite + nitrate, total & 1.8 & 1.6 \\
Phosphorus, total & 0.080 & 0.075 \\
Orthophosphate, dissolved & 0.013 & 0.013 \\
Chloride, dissolved & $\mathbf{1 3 4}$ & $\mathbf{1 7 0}$ \\
Sulfate, dissolved & 68.5 & 62.0 \\
\hline
\end{tabular}

Detention basins have been shown to reduce concentrations of contaminants contained in storm runoff (Zarriello and Sherwood, 1993 and Sherwood, 2001b). A statistical analysis (Wilcoxon rank sum test) was used to compare constituent concentrations from before construction of the detention basin to those obtained after. Because water in East Branch Allen Creek during the navigation season is comprised primarily of water diverted from the canal (table 11), only concentrations obtained during the nonnavigation season were used for the comparison. Mean concentrations of all constituents, except chloride and sulfate, were lower after construction of the detention basin and suspended solids and nitrogen ammonia + organic were significantly lower (table 19).

Irondequoit Creek at Railroad Mills, in contrast, shows an increase in yield of all constituents except ammonia and dissolved sulfate over the three reporting periods. The higher yields for the 1997-99 period result from the large amount of runoff for 1998. Yields of chloride at the downstream sites, which drain urbanized areas, are little changed since the first report, Johnston and Sherwood (1996) and range from 173 ton $/ \mathrm{mi}^{2}$ at Allen Creek to 121 ton $/ \mathrm{mi}^{2}$ at East Branch Allen Creek. Yields of chloride upstream at Railroad Mills, whose drainage area is more agricultural and has a lower percentage of impervious area, is considerably lower $\left(76.9 \mathrm{ton} / \mathrm{mi}^{2}\right)$ than at the other Irondequoit Creek sites.

\section{Western Monroe County Sites}

Mean annual yields of nutrients, at Northrup Creek for water years 1997-99 were higher than at any of the other Monroe County sites. Ammonia and ammonia + organic nitrogen yields were little changed from previous periods, whereas nitrite + nitrate was higher and total phosphorus and orthophosphate were lower. The lower mean annual loads of total phosphorus and orthophosphate for 1997-99 are a continued indication of the improved phosphorus treatment at the Spencerport sewage-treatment plant begun in the summer of 1995. The apparent lack of greater improvement for total phosphorus is a result of

Table 20. Annual constituent loads with associated error and annual yield, for Genesee River at Charlotte Pump Station, Monroe County, N.Y., water years 1997-99.

[Loads are annual total in thousands of tons. Error multiplied by 1.96 and added to and subtracted from the estimated load gives approximate 95-percent confidence limits of load estimate. Yield in tons per square per mile. Location is shown in fig. 1.]

\begin{tabular}{|c|c|c|c|c|c|c|c|c|c|}
\hline \multirow[b]{2}{*}{ Constituent } & \multicolumn{2}{|c|}{1997} & \multicolumn{2}{|c|}{1998} & \multicolumn{2}{|c|}{1999} & \multicolumn{3}{|c|}{ Yield } \\
\hline & Load & Error & Load & Error & Load & Error & 1997 & 1998 & 1999 \\
\hline Suspended solids & 417 & 72 & 560 & 121 & 161 & 37 & 169 & 227 & 65.3 \\
\hline Volatile solids & 31.3 & 8.12 & 42.7 & 13.3 & 12.1 & 4.58 & 12.7 & 17.3 & 4.90 \\
\hline Ammonia as $\mathrm{N}$, dissolved & .279 & .023 & .262 & .021 & .158 & .013 & .113 & .106 & .064 \\
\hline $\begin{array}{l}\text { Ammonia + organic nitrogen as } \mathrm{N}, \\
\text { total }\end{array}$ & 1.75 & .14 & 1.87 & .15 & .83 & .065 & .71 & .76 & .34 \\
\hline Nitrite + nitrate as $\mathrm{N}$, total & 3.41 & .19 & 3.72 & .21 & 1.71 & .10 & 1.38 & 1.51 & .69 \\
\hline Phosphorus as $\mathrm{P}$, total & .40 & .043 & .53 & .063 & .17 & .019 & .16 & .21 & .069 \\
\hline Orthophosphate as P, dissolved & .069 & .006 & .077 & .007 & .035 & .003 & .028 & .031 & .014 \\
\hline Chloride, dissolved & 120 & 5.32 & 129 & 5.67 & 71.4 & 3.24 & 48.6 & 52.3 & 28.9 \\
\hline Sulfate, dissolved & 156 & 5.69 & 166 & 5.99 & 99.1 & 3.68 & 63.2 & 67.3 & 40.2 \\
\hline
\end{tabular}


the higher daily mean streamflows for the years after phosphorus control than those in the preceding period. Total phosphorus, which adheres to suspended particulate matter, generally shows a positive correlation with streamflow. Although Northrup Creek's drainage area is mainly agricultural, the relatively high nutrient yields (compared to the Irondequoit Creek basin) are derived primarily from sewage-treatment-plant discharge upstream from the sampling site and, to a lesser extent, from fertilizers, agricultural runoff, water diverted from the New York State Barge Canal, septic systems, and atmospheric deposition. Mean annual yields of total suspended solids and volatile suspended solids for 1997-99 were considerably lower (159 ton $/ \mathrm{mi}^{2}$ and $20.5 \mathrm{ton} / \mathrm{mi}^{2}$, respectively) than for the two previous periods, even though runoff for 1997-99 was slightly greater (table 18). Mean annual yields of chloride and sulfate for 1997-99 were higher than for the two previous periods as a result of the greater runoff during that period. Mean annual yields of chloride at Black Creek, Oatka Creek and Honeoye Falls are much lower than those at Northrup Creek and about the same as those in the Genesee River. The higher chloride yields at Northrup Creek are probably a result of discharge from the Spencerport sewage-treatment plant.

Annual loads of constituents in the Genesee River (table 20) were estimated from streamflow data collected at the Genesee River at Rochester gaging station (04232000) and concentration data collected at the Charlotte Pump Station, about 5 mi downstream (fig 1). Yields for all constituents were within the range of those noted for the other sites in Monroe County. Loads and yields of all constituents for water year 1999 were considerably lower than for water years 1997-98. The annual mean flow of $1,660 \mathrm{ft}^{3} / \mathrm{s}$ for 1999 was only 60 percent of the 3-year mean annual flow of $2,760 \mathrm{ft}^{3} / \mathrm{s}$ for $1997-99$.

\section{SUMMARY AND CONCLUSIONS}

Many years of systematic collection of hydrologic data in Monroe County have provided a foundation for a comprehensive assessment of the county's water resources. Long-term records of precipitation and unregulated streamflow provide the basis for determining the normality of much shorter periods of record, such as the 1997-99 water-year period analyzed in this report.
Precipitation records collected by the National Weather Service at Rochester indicate that average annual rainfall for 1997-99 was 38.44 in., 6.48 in. above normal. Precipitation for 1998 was 13.9 in. above normal, that for 1997 was $6.82 \mathrm{in}$. above normal, and that for 1999 was 1.3 in below normal. A storm on January 8, 1998 produced period-of-record, or near period-of-record, flows at the Irondequoit basin sites and contributed to the above normal precipitation and high annual constituent loads for 1998. Annual yields of chemicals deposited on the Irondequoit Creek Basin from atmospheric sources during 1997-99 were generally higher than during the previous (1984-96) report period; the ammonia yield was 144 percent higher, the dissolved potassium yield was 118 percent higher and the sodium yield 87 percent higher. These high yields are attributed partly to the above normal precipitation during 1997-99 and in the case of ammonia, is probably a result of increased local applications of fertilizer upwind of the collection site. Decreases were noted in yields of magnesium (6.4 percent), orthophosphate (30 percent), and sulfate (36 percent).

Loads of all nutrients deposited on the Irondequoit basin from atmospheric sources during 1997-99 greatly exceeded those transported by Irondequoit Creek. The ammonia load deposited on the basin was 139 times the load transported at Blossom Road (the most downstream site); the ammonia + organic nitrogen load was 6.3 times greater, orthophosphate 7.5 times greater, total phosphorus 1.3 times greater and nitrite + nitrate 1.5 times greater. Average yields of dissolved chloride and dissolved sulfate from atmospheric sources were much smaller than those transported by streamflow at Blossom Road - chloride was about 2 percent and sulfate about 8 percent of the amount deposited.

Ground-water levels in Ellison Park wells indicate that water-table gradients are subject to reversals in lateral flow in the aquifer. Trend analysis of ground-water levels in Ellison Park wells for the period of record through 1999 showed upward trends of 0.11 percent per year at Mo 659 (well finished in the lower confined part of the aquifer), and 5.9 percent per year at Mo 667 (well finished in the upper unconfined part of the aquifer).

Concentrations of chemical constituents in Ellison Park wells showed a total of 75 statistically significant trends. The well with the highest number of significant trends was Mo 3, where 11 of the 
constituents showed a downward trend, and 1 showed an upward trend. the well with the fewest statistically significant trends (4) was Mo 664. Turbidity was the constituent that showed a trend at the greatest number of wells (4 upward, and 4 downward). Common ions were the constituents that showed the greatest number of trends among wells, and nutrients showed the fewest.

Monthly mean streamflow for the four monitored streams in the Irondequoit Creek basin were generally at or near normal values (25th to 75 th percentile), except for January which was above 75 th percentile, and April and May which were near or below the 25th percentile. Streamflow at the four monitored sites in western Monroe County was near or above normal (75th percentile) for October through February, slightly below normal for April, and near or slightly above normal for the remainder of the 1998 water year. Trend analysis of the monthly mean flows at sites in the Irondequoit Creek basin and Northrup Creek indicated a significiant downward trend in streamflow at Allen Creek (1.25 percent per year; 1984-99) and an upward trend at Northrup Creek (4.3 percent per year; 1989-99) for the period during which water quality data have been collected at these sites.

Streamflow temperatures in the Irondequoit Creek basin were typical of the large, low-gradient streams in New York. Maximum daily temperatures during 1997-99 exceeded $22.0^{\circ} \mathrm{C}$ on many days during the summer months at all sites, but daily mean temperatures for those days generally were lower than 22. $0^{\circ} \mathrm{C}$, and those at Railroad Mills never exceeded that limit. No minimum temperatures at any of the sites exceeded $22.0^{\circ} \mathrm{C}$.

Median concentrations of most constituents were relatively uniform among the four sites in the Irondequoit Creek basin. Among the nutrients, nitrite + nitrate showed the greatest range in concentration, from $0.71 \mathrm{mg} / \mathrm{L}$ at East Branch Allen Creek to $1.1 \mathrm{mg} /$ $\mathrm{L}$ at Irondequoit Creek at Railroad Mills. The highest median concentration of ammonia + organic nitrogen $(0.51 \mathrm{mg} / \mathrm{L})$ was at East Branch Allen Creek, and the lowest $(0.34 \mathrm{mg} / \mathrm{L})$ was at Railroad Mills. Median concentrations of total phosphorus ranged from 0.075 $\mathrm{mg} / \mathrm{L}$ to $0.095 \mathrm{mg} / \mathrm{L}$ whereas those for orthophosphate ranged from $0.008 \mathrm{mg} / \mathrm{L}$ to $0.020 \mathrm{mg} / \mathrm{L}$.

Orthophosphate was the constituent with the greatest number of statistically significant differences in median concentration among sites in the Irondequoit Creek basin. The highest median concentration of chloride (158 mg/L) occurred at Allen Creek, whereas the highest median concentration of sulfate (152 mg/L) was at Irondequoit Creek at Railroad Mills. Median concentrations of these constituents for 1997-99, were higher than for previous periods and showed statistically significant differences among most of the sites. Median concentrations of total suspended solids were highest at Allen Creek and Railroad Mills (139 and 136 mg/L), respectively. Median concentrations of nutrients in Northrup Creek were higher than those found at the Irondequoit basin sites, but lower than during previous periods because of the improved treatment of phosphorus upstream at Spencerport. Median concentrations of constituents at the other western Monroe County sites were within the range of those noted at the Irondequoit sites.

Period-of-record trends for constituents at sites in the Irondequoit Creek basin differed from site to site and in magnitude and direction. Statistically significant downward trends in the concentration of ammonia + organic nitrogen, ranging from 4.1 percent per year at Allen Creek to 5.6 percent per year at East Branch Allen Creek, were noted at three of the four Irondequoit Creek basin sites. Railroad Mills was the exception, where ammonia + organic nitrogen showed no trend. Orthophosphate showed an upward trend of 4.1 percent per year at Railroad Mills. Dissolved chloride showed upward trends at Railroad Mills, Allen Creek, and Blossom Road; these ranged from greater than 0.01 percent per year at Allen Creek to 4.0 percent per year at Railroad Mills. Dissolved sulfate showed downward trends of 1.7 percent per year at Allen Creek and 0.4 percent per year at Blossom Road. Suspended solids showed an upward trend of 13.7 percent per year at Railroad Mills and a downward trend of 2.7 percent per year at Blossom Road.

Northrup Creek showed statistically significant downward trends in ammonia + organic nitrogen (3.3 percent per year), total phosphorus (3.4 percent per year), and orthophosphate (5.5 percent per year), and an upward trend in sulfate (1.8 percent per year). The Genesee River showed downward trends in ammonia + organic nitrogen (6.1 percent per year) and chloride (0.1 percent per year), and upward trends in total phosphorus (1.7 percent per year) and orthophosphate (6.6 percent per year).

Loads of chemical constituents transported to Irondequoit Bay during 1997-99 were generally greater than those for 1994-96. Total suspended solids 
were transported at the rate of 15,600 ton/yr, of which volatile suspended solids constituted about 2,220 tons. Nutrient transport to the bay averaged 91.9 ton/yr for ammonia + organic nitrogen, 175 ton/yr for nitrite + nitrate, 6.3 ton/yr for ammonia, 19.1 ton/yr for total phosphorus, and 2.8 ton/yr for orthophosphate.

Dissolved chloride transported to the bay averaged $21,100 \mathrm{ton} / \mathrm{yr}$, and sulfate transported averaged 16,900 ton/yr.

Generally, mean annual yields of constituents were similar among the four Irondequoit Creek basin sites. Irondequoit Creek at Railroad Mills had the highest yields of total and volatile suspended solids (190 and $23.2 \mathrm{ton} / \mathrm{mi}^{2}$, respectively) and the lowest yield of chloride $\left(76.9 \mathrm{ton} / \mathrm{mi}^{2}\right)$. Allen Creek had the highest yield of dissolved chloride. East Branch Allen Creek had the highest yields of all nutrients in the Irondequoit basin. Northrup Creek had higher yields of all nutrients than any of the Irondequoit basin sites. The yields of all constituents at East Branch Allen Creek decreased after 1995 as a result of to the construction of a stormwater-detention basin on the main channel of the creek upstream the monitoring site. The high yields of nutrients at Northrup Creek are a result of the discharge from an upstream waste-water treatment plant and, to a lesser extent, agricultural runoff. Annual yields of constituents in the Genesee River were within the range of those found at Northrup Creek and the Irondequoit basin sites.

Surface-water quality data collected during 199799 showed that streamwater quality was similar to that of the previous periods of record, but with some differences. Concentrations of ammonia + organic nitrogen, nitrite + nitrate, total phosphorus, and orthophosphate for 1997-99 were either similar to, or lower than those for the preceding period of record at all sites. Concentrations of dissolved chloride were higher at all sites, and those for dissolved sulfate were lower. Northrup Creek continues to have the highest concentrations of all nutrients, but those concentrations are generally declining in response to additional treatment by the sewage-treatment plant at Spencer port. Chloride concentrations at Northrup Creek however, continue to increase in response to increasing development within the basin and increased runoff.

The data revealed some general differences among basins for the 1997-99 period. Northrup Creek had the highest concentrations of nutrients, whereas Irondequoit Creek at Railroad Mills, with the exception of nitrite + nitrate had the lowest. Irondequoit Creek at Railroad Mills, which is largely agricultural, had the lowest concentrations of chloride, and the highest concentrations of sulfate. Allen Creek, the most urbanized of the subbasins had the highest concentrations of chloride. Northrup Creek had the highest yields of nutrients of any of the sites, but these yields are influenced by sewagetreatment plant releases.

Water quality management practices and improved treatment, or diversion, of sewage-treatment plant effluent continue to decrease the median concentration of some constituents (particularly nutrients) in surface water throughout Monroe County. Although the 1997-99 loads of most constituents delivered to Irondequoit Bay, were greater than during previous periods, the concentrations of those constituents during 1997-99 were lower.

\section{REFERENCES CITED}

Bidgood, B.F. and Berst, A.H., 1969, Lethal temperatures for Great Lakes rainbow trout: Journal of Fisheries Research Board Canada, v. 26, p. 456-459.

Brown, L.C. and Johnson, J.W., 1996, Nitrogen and the Hydrologic Cycle: Ohio State University Fact Sheet, AEX-463-96, 6 p.

Bubeck, R.C. and Burton, R.S., 1989, Changes in chloride concentrations, mixing patterns, and stratification characteristics of Irondequoit Bay, Monroe County, New York, after decreased use of road-deicing salts, 1974-84: U.S. Geological Survey Water-Resources Investigation Report 87-4223, 52 p.

Cleveland, W.S., 1979, Robust locally weighted regression and smoothing scatterplots: Journal of the American Statistical Association, v. 74, p. 829-836.

Cohn, T.A., DeLong, L.L, Gilroy, E.J., Hirsch, R.M., and Wells, D.K., 1989, Estimating constituent loads: Water Resources Research, v. 25, no. 5, p. 937-942.

Cohn, T.A., Caulder, D.L., Gilroy, E.J., Zynjuk, L.D., and Summers, R.M., 1992, The validity of a simple statistical model for estimating fluvial constituent loads - an empirical study involving nutrient loads entering Chesapeake Bay: Water Resources Research, v. 28, no. 9, p. 2353-2363.

Coon, W.F., 1997, Hydrology, sedimentology, and biology of Ellison Park wetland at the mouth of Irondequoit Creek near Rochester, New York: U.S. Geological Survey Water-Resources Investigations Report 96-4269, 41 p.

Coon, W.F., Bernard, J.M., and Seischab, F.K., 2000, Effects of a cattail wetland on water quality of Irondequoit Creek near Rochester, New York: U.S. 
Geological Survey Water-Resources Investigations Report 00-4032, 74 p.

Heffner, R.L., and Goodman, S.D., 1973, Soil survey of Monroe County, New York: U.S. Department of Agriculture, $172 \mathrm{p}$.

Hirsch, R.M., Slack, J.R., and Smith, R.A., 1982, Techniques of trend analysis for monthly water quality data: Water Resources Research, v. 18, no. 1, p. 107-121.

Johnston, W.H., and Sherwood, D.A., 1996, Water Resources of Monroe County New York, Water Years 1984-88, with emphasis on water quality in the Irondequoit Creek basin, part 2: U.S. Geological Survey Open-File Report 96-4054, 84 p.

Kappel, W.M., Yager, R.M., and Zarriello, P.J., 1986, Quantity and quality of urban storm runoff in the Irondequoit Creek basin near Rochester, New York, Part 2-Quality of storm runoff and atmospheric deposition, rainfall-runoff-quality modeling, and potential of wetlands for sediment and nutrient retention: U.S. Geological Survey Water-Resources Investigations Report 85-4113, 93 p.

Kappel, W.M. and Young, R.A., 1989, Glacial history and geohydrology of the Irondequoit Creek valley, Monroe County, New York: U.S. Geological Survey WaterResources Investigations Report 88-4145, 34 p.

Lanfear, K.J. and Alexander, R.B., 1990, Methodology to derive water-quality trends for use by the national water summary program of the U.S. Geological Survey: U.S. Geological Survey Open-File Report 90-359, $10 \mathrm{p}$.

Makarewicz, J.C., Lewis, T.W., Brooks, Anna, and others, 1990, Chemical analysis and nutrient loading of Salmon Creek, Otis Creek, Black Creek, Spencerport Sewage Treatment Plant, Precipitation falling in Western Monroe County, with a discussion on the trophic status of Long Pond and stress stream analysis of Northrup Creek and Buttonwood Creeks: Brockport, N.Y., State University of New York at Brockport, unpublished report, $120 \mathrm{p}$.

National Oceanic and Atmospheric Administration, 198399, Climatological data annual summary, New York: Asheville, N.C., National Climatic Data Center, no. 13, v. 106-108 [issued annually].
Sen, P.K., 1968, Estimates of regression coefficient based on Kendall's tau: Journal of the American Statistical Association, v. 63, p. 1379-1389.

Sherwood, D.A., 1999, Water Resources of Monroe County New York, Water Years 1989-93, with emphasis on water quality in the Irondequoit Creek basin, part 2: U.S. Geological Survey Water-Resources Investigations Report 99-4084, 50 p.

Sherwood, D.A., 2001, Water Resources of Monroe County New York, Water Years 1994-96, with emphasis on water quality in the Irondequoit Creek basin: U.S. Geological Survey Water-Resources Investigations Report 00-4201, 44 p.

Sherwood, D.A., 2001, Effects of a Vegetated StormwaterDetention Basin on Chemical Quality and Temperature of Runoff from a Small Residential Development in Monroe County, New York: U.S. Geological Survey Water-Resources Investigations Report 01-4099, 11 p.

Wagner, L.A., and Dixson, H.L., 1985, Drainage areas of New York streams by river basins-a stream gazetteer: U.S. Geological Survey Open-File Report 81-1055, 359 p.

Yager, R.M., Zarriello, P.J., and Kappel, W.M., 1985, Geohydrology of the Irondequoit Creek basin near Rochester, New York: U.S. Geological Survey WaterResources Investigations Report 84-4259, 6 pl.

Young, R.A., 1993, Analysis and recommendations for ground-water sampling program (1988-93), Irondequoit Creek basin, with emphasis on the Ellison Park-Browncroft Boulevard reach: Rochester, N.Y., Monroe County Health Department, unpublished report, $20 \mathrm{p}$.

Zarriello, P.J., and Sherwood, D.A., 1993, Effect of stormwater detention on the chemical quality of runoff from a small residential development, Monroe County, New York: U.S. Geological Survey Water-Resources Investigations Report 92-4003, 57 p. 

Irondequoit Creek Basin 


\section{APPENDIX}

Estimated monthly loads and associated error for nine constituents at four sites in the Irondequoit Creek basin and at four sites in western Monroe County, N.Y., water years 1997-99

\section{Irondequoit Creek basin:}

Irondequoit Creek at Railroad Mills $(1997-99) \ldots \ldots \ldots \ldots \ldots \ldots \ldots \ldots \ldots \ldots \ldots \ldots$

East Branch Allen Creek at Pittsford $(1997-99) \ldots \ldots \ldots \ldots \ldots \ldots \ldots \ldots \ldots \ldots \ldots \ldots$

Allen Creek near Rochester $(1997-99) \ldots \ldots \ldots \ldots \ldots \ldots \ldots \ldots \ldots \ldots \ldots \ldots \ldots \ldots$

Irondequoit Creek at Blossom Road $(1997-99) \ldots \ldots \ldots \ldots \ldots \ldots \ldots \ldots \ldots \ldots \ldots \ldots \ldots \ldots \ldots$

\section{Western Monroe County:}

Northrup Creek at North Greece $(1997-99) \ldots \ldots \ldots \ldots \ldots \ldots \ldots \ldots \ldots \ldots \ldots \ldots \ldots$

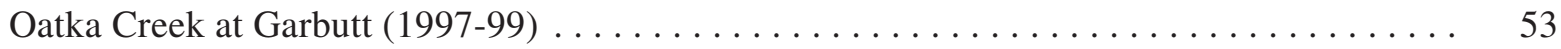

Honeoye Creek at Honeoye Falls $(1998-99) \ldots \ldots \ldots \ldots \ldots \ldots \ldots \ldots \ldots \ldots \ldots \ldots \ldots$

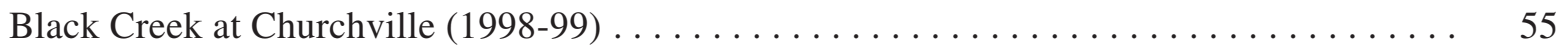


Appendix. Estimated monthly loads and associated error for nine constituents at four sites in the Irondequoit Creek basin and at four sites in western Monroe County, N.Y., water years 1997-99.

[Loads are in tons. Error when multiplied by 1.96 and added to or subtracted from the estimated load, provides the 95-percent confidence limits of the load estimate. Dashes indicate no data. Locations are shown in figure.]

\begin{tabular}{|c|c|c|c|c|c|c|c|c|c|c|c|}
\hline & $\begin{array}{l}\text { Total } \\
\text { suspended } \\
\text { solids }\end{array}$ & $\begin{array}{l}\text { Volatile } \\
\text { suspended } \\
\text { solids }\end{array}$ & $\begin{array}{c}\text { Ammonia } \\
\text { nitrogen as } \\
\mathrm{N} \text {, dissolved }\end{array}$ & $\begin{array}{c}\text { Ammonia }+ \\
\text { organic } \\
\text { nitrogen as } \\
\mathrm{N} \text {, total }\end{array}$ & $\begin{array}{l}\text { Nitrite }+ \\
\text { nitrate as } \mathrm{N}, \\
\text { total }\end{array}$ & $\begin{array}{c}\text { Total } \\
\text { phosphaous, } \\
\text { as P }\end{array}$ & $\begin{array}{r}\text { Ort } \\
\text { phos } \\
\text { as } \\
\text { disse }\end{array}$ & $\begin{array}{l}\text { ho- } \\
\text { ohate } \\
\text { P, } \\
\text { lved }\end{array}$ & $\begin{array}{l}\text { Chlc } \\
\text { diss }\end{array}$ & $\begin{array}{l}\text { ride, } \\
\text { olved }\end{array}$ & $\begin{array}{l}\text { Sulfate, } \\
\text { dissolved }\end{array}$ \\
\hline Month & Load Error & Load Error & Load Error & Load Error & Load Error & Load Error & Load & Error & Load & Error & Load Error \\
\hline
\end{tabular}

\section{Irondequoit Creek at Railroad Mills (04232034)}

\section{Water year 1997}

\begin{tabular}{|c|c|c|c|c|c|c|c|c|c|c|c|c|c|c|c|c|c|}
\hline \multirow[b]{2}{*}{ NOV } & 412 & 343 & 49.0 & 30.8 & 0.067 & 0.026 & 3.17 & 1.08 & 3.77 & 0.33 & 0.80 & 0.40 & 0.066 & 0.013 & 295 & 21 & 672 \\
\hline & 763 & 492 & 82.1 & 38.7 & 0.144 & 0.062 & 2.87 & 1.09 & 3.88 & 0.46 & 0.66 & 0.28 & 0.058 & 0.010 & 360 & 23 & 636 \\
\hline DEC & 854 & 512 & 92.2 & 41.0 & 0.196 & 0.092 & 3.50 & 1.27 & 5.55 & 0.64 & 0.69 & 0.23 & 0.060 & 0.008 & 454 & 26 & 700 \\
\hline JAN & 216 & 118 & 30.8 & 12.9 & 0.034 & 0.010 & 1.50 & 0.39 & 4.12 & 0.31 & 0.19 & 0.05 & 0.020 & 0.002 & 249 & 14 & 467 \\
\hline FEB & 304 & 214 & 36.2 & 19.6 & 0.042 & 0.015 & 1.87 & 0.57 & 5.44 & 0.48 & 0.30 & 0.10 & 0.028 & 0.004 & 311 & 18 & 519 \\
\hline MAR & 480 & 283 & 55.6 & 26.2 & 0.095 & 0.030 & 2.46 & 0.70 & 7.16 & 0.62 & 0.38 & 0.09 & 0.028 & 0.003 & 498 & 26 & 740 \\
\hline APR & 210 & 127 & 32.3 & 15.5 & 0.061 & 0.017 & 1.59 & 0.39 & 4.54 & 0.34 & 0.20 & 0.05 & 0.012 & 0.001 & 337 & 18 & 605 \\
\hline MAY & 194 & 113 & 34.2 & 15.3 & 0.053 & 0.016 & 1.80 & 0.52 & 3.85 & 0.35 & 0.31 & 0.10 & 0.014 & 0.002 & 230 & 13 & 561 \\
\hline JUN & 454 & 232 & 58.3 & 23.5 & 0.088 & 0.025 & 1.98 & 0.56 & 3.86 & 0.35 & 0.56 & 0.16 & 0.026 & 0.003 & 197 & 12 & 520 \\
\hline JUL & 262 & 176 & 31.5 & 17.3 & 0.037 & 0.013 & 0.51 & 0.17 & 2.03 & 0.20 & 0.19 & 0.06 & 0.013 & 0.002 & 101 & 7 & 320 \\
\hline AUG & 110 & 73 & 15.9 & 8.7 & 0.010 & 0.003 & 0.36 & 0.12 & 1.63 & 0.14 & 0.10 & 0.03 & 0.009 & 0.001 & 90 & 6 & 318 \\
\hline SEP & 100 & 81 & 17.1 & 10.7 & 0.006 & 0.002 & 0.77 & 0.24 & 1.80 & 0.14 & 0.15 & 0.06 & 0.015 & 0.002 & 119 & 8 & 405 \\
\hline Total & 4359 & 2764 & 535.2 & 260.2 & 0.833 & 0.311 & 22.38 & 7.10 & 47.63 & 4.36 & 4.53 & 1.61 & 0.349 & 0.051 & 3241 & 192 & 6463 \\
\hline
\end{tabular}

\section{Water year 1998}

\begin{tabular}{|c|c|c|c|c|c|c|c|c|c|c|c|c|c|c|c|c|c|}
\hline OCT & 186 & 134 & 31.2 & 18.4 & 0.009 & 0.004 & 0.76 & 0.22 & 1.68 & 0.13 & 0.12 & 0.03 & 0.017 & 0.002 & 141 & 9 & 413 \\
\hline NOV & 871 & 542 & 104.3 & 52.1 & 0.067 & 0.027 & 1.76 & 0.65 & 2.76 & 0.34 & 0.34 & 0.09 & 0.039 & 0.005 & 284 & 17 & 530 \\
\hline DEC & 738 & 433 & 95.1 & 45.2 & 0.066 & 0.025 & 1.80 & 0.60 & 3.57 & 0.40 & 0.29 & 0.07 & 0.033 & 0.004 & 315 & 18 & 534 \\
\hline JAN & 1694 & 1147 & 183.2 & 87.4 & 0.167 & 0.063 & 5.65 & 1.51 & 8.96 & 0.65 & 1.98 & 1.06 & 0.164 & 0.036 & 561 & 35 & 849 \\
\hline FEB & 941 & 560 & 102.6 & 47.2 & 0.054 & 0.015 & 2.85 & 0.69 & 6.84 & 0.49 & 0.56 & 0.16 & 0.054 & 0.006 & 428 & 24 & 663 \\
\hline MAR & 1135 & 616 & 123.5 & 52.8 & 0.095 & 0.024 & 2.87 & 0.66 & 7.31 & 0.52 & 0.55 & 0.14 & 0.045 & 0.005 & 551 & 29 & 793 \\
\hline APR & 353 & 218 & 55.5 & 27.7 & 0.045 & 0.010 & 1.42 & 0.28 & 3.90 & 0.24 & 0.20 & 0.05 & 0.014 & 0.001 & 317 & 17 & 574 \\
\hline MAY & 224 & 135 & 43.7 & 20.9 & 0.026 & 0.007 & 1.09 & 0.30 & 2.68 & 0.23 & 0.19 & 0.05 & 0.011 & 0.001 & 177 & 11 & 453 \\
\hline JUN & 791 & 495 & 92.1 & 39.0 & 0.062 & 0.019 & 1.35 & 0.38 & 2.80 & 0.24 & 0.54 & 0.21 & 0.028 & 0.004 & 153 & 10 & 425 \\
\hline JUL & 2603 & 1782 & 205.3 & 97.7 & 0.198 & 0.078 & 2.77 & 0.94 & 4.55 & 0.41 & 2.01 & 0.92 & 0.092 & 0.017 & 253 & 18 & 598 \\
\hline AUG & 369 & 207 & 45.7 & 20.3 & 0.014 & 0.004 & 0.60 & 0.16 & 2.03 & 0.14 & 0.20 & 0.05 & 0.018 & 0.002 & 125 & 8 & 400 \\
\hline SEP & 176 & 121 & 31.0 & 17.6 & 0.004 & 0.002 & 0.64 & 0.15 & 1.69 & 0.11 & 0.14 & 0.03 & 0.016 & 0.002 & 120 & 7 & 416 \\
\hline Total & 0081 & 6390 & 13.2 & 5263 & 0.807 & 0.278 & 3.56 & 6.54 & 48.77 & 3.90 & 7.12 & 2.86 & 0.531 & 0.085 & 3425 & 203 & 648 \\
\hline
\end{tabular}

\section{Water year 1999}

\begin{tabular}{|c|c|c|c|c|c|c|c|c|c|c|c|c|c|c|c|c|c|c|}
\hline OCT & 295 & 235 & 51.7 & 34.3 & 0.006 & 0.003 & 0.68 & 0.21 & 1.48 & 0.13 & 0.13 & 0.04 & 0.019 & 0.003 & 136 & 9 & 400 & 28 \\
\hline NOV & 454 & 415 & 73.1 & 55.5 & 0.016 & 0.007 & 0.51 & 0.21 & 1.30 & 0.17 & 0.10 & 0.03 & 0.016 & 0.002 & 143 & 11 & 322 & 25 \\
\hline DEC & 402 & 348 & 67.3 & 48.3 & 0.017 & 0.007 & 0.54 & 0.19 & 1.64 & 0.20 & 0.09 & 0.03 & 0.014 & 0.002 & 155 & 10 & 315 & 22 \\
\hline JAN & 1066 & 899 & 127.2 & 72.6 & 0.033 & 0.013 & 2.02 & 0.64 & 4.01 & 0.31 & 0.61 & 0.35 & 0.062 & 0.014 & 266 & 18 & 466 & 0 \\
\hline FEB & 1016 & 601 & 124.3 & 58.5 & 0.022 & 0.006 & 1.73 & 0.39 & 4.56 & 0.31 & 0.33 & 0.09 & 0.040 & 0.005 & 310 & 17 & 522 & 31 \\
\hline MAR & 2006 & 1264 & 217.8 & 108.5 & 0.080 & 0.019 & 2.64 & 0.58 & 6.38 & 0.43 & 0.62 & 0.18 & 0.053 & 0.006 & 530 & 29 & 759 & 3 \\
\hline APR & 671 & 479 & 106.7 & 62.6 & 0.040 & 0.008 & 1.55 & 0.31 & 3.83 & 0.24 & 0.26 & 0.06 & 0.019 & 0.002 & 341 & 18 & 608 & 33 \\
\hline MAY & 317 & 227 & 66.0 & 39.0 & 0.016 & 0.005 & 0.80 & 0.23 & 2.16 & 0.20 & 0.16 & 0.04 & 0.011 & 0.001 & 156 & 10 & 415 & 27 \\
\hline JUN & 522 & 392 & 78.5 & 48.0 & 0.017 & 0.006 & 0.46 & 0.15 & 1.49 & 0.16 & 0.19 & 0.06 & 0.014 & 0.002 & 87 & 7 & 285 & 4 \\
\hline JUL & 646 & 508 & 83.0 & 54.3 & 0.018 & 0.006 & 0.34 & 0.10 & 1.39 & 0.14 & 0.18 & 0.06 & 0.015 & 0.002 & 82 & 7 & 271 & 2 \\
\hline AUG & 336 & 246 & 48.8 & 29.5 & 0.006 & 0.002 & 0.29 & 0.08 & 1.24 & 0.10 & 0.12 & 0.03 & 0.013 & 0.002 & 81 & 6 & 290 & 1 \\
\hline SEP & 179 & 152 & 35.8 & 25.3 & 0.002 & 0.001 & 0.35 & 0.10 & 1.09 & 0.09 & 0.09 & 0.03 & 0.013 & 0.002 & 83 & 6 & 315 & 23 \\
\hline Total & 910 & 766 & 080.2 & 636.4 & 0.273 & 0.083 & 11.91 & 3.19 & 30.57 & 2.48 & 2.88 & 1.00 & 0.289 & 0.043 & 2370 & 148 & 4968 & \\
\hline
\end{tabular}


Appendix. (continued) Estimated monthly loads and associated error for nine constituents at four sites in the Irondequoit Creek basin and at four sites in western Monroe County, N.Y., water years 1997-99.

\begin{tabular}{|c|c|c|c|c|c|c|c|c|c|c|}
\hline & $\begin{array}{c}\text { Total } \\
\text { suspended } \\
\text { solids }\end{array}$ & $\begin{array}{l}\text { Volatile } \\
\text { suspended } \\
\text { solids }\end{array}$ & $\begin{array}{c}\text { Ammonia } \\
\text { nitrogen as } \\
\mathrm{N} \text {, dissolved }\end{array}$ & $\begin{array}{c}\text { Ammonia + } \\
\text { organic } \\
\text { nitrogen as } \\
\mathrm{N} \text {, total }\end{array}$ & $\begin{array}{c}\text { Nitrite }+ \\
\text { nitrate as } \mathrm{N} \\
\text { total }\end{array}$ & $\begin{array}{r}\text { To } \\
\text { phosp } \\
\text { as }\end{array}$ & $\begin{array}{l}\text { tal } \\
\text { thaous, } \\
\text { s P }\end{array}$ & $\begin{array}{c}\text { Ortho- } \\
\text { phosphate } \\
\text { as P, } \\
\text { dissolved }\end{array}$ & & $\begin{array}{l}\text { Sulfate, } \\
\text { dissolved }\end{array}$ \\
\hline Month & Load Error & Load Error & Load Error & Load Error & Load Error & Load & Error & Load Error & Load Error & Load Error \\
\hline
\end{tabular}

\section{East Branch Allen Creek at Pittsford (0423204920)}

\section{Water year 1997}

\begin{tabular}{|c|c|c|c|c|c|c|c|c|c|c|c|c|c|c|c|c|c|c|}
\hline OCT & 303 & 182 & 36.7 & 18.8 & 0.025 & 0.010 & 1.04 & 0.18 & 1.56 & 0.28 & 0.51 & 0.13 & 0.091 & 0.030 & 93 & 10 & 92 & 10 \\
\hline $\mathrm{NOV}$ & 156 & 84 & 23.0 & 10.5 & 0.027 & 0.012 & 0.94 & 0.17 & 1.67 & 0.32 & 0.32 & 0.07 & 0.060 & 0.017 & 115 & 11 & 84 & \\
\hline DEC & 107 & 57 & 18.6 & 8.5 & 0.040 & 0.017 & 1.02 & 0.19 & 2.01 & 0.39 & 0.23 & 0.05 & 0.041 & 0.011 & 193 & 18 & 89 & \\
\hline JAN & 34 & 16 & 6.6 & 2.7 & 0.021 & 0.007 & 0.34 & 0.05 & 0.87 & 0.13 & 0.05 & 0.01 & 0.008 & 0.002 & 122 & 11 & 43 & \\
\hline FEB & 60 & 35 & 9.4 & 4.8 & 0.022 & 0.008 & 0.46 & 0.07 & 2.61 & 0.45 & 0.08 & 0.02 & 0.013 & 0.003 & 181 & 18 & 50 & \\
\hline MAR & 68 & 37 & 10.1 & 5.0 & 0.024 & 0.008 & 0.77 & 0.12 & 4.47 & 0.70 & 0.12 & 0.02 & 0.016 & 0.003 & 250 & 21 & 83 & 7 \\
\hline APR & 18 & 10 & 2.8 & 1.4 & 0.010 & 0.003 & 0.29 & 0.04 & 0.90 & 0.15 & 0.04 & 0.01 & 0.003 & 0.001 & 82 & 8 & 43 & \\
\hline MAY & 26 & 14 & 4.3 & 2.0 & 0.020 & 0.007 & 0.30 & 0.04 & 0.37 & 0.06 & 0.05 & 0.01 & 0.004 & 0.001 & 52 & 5 & 43 & \\
\hline JUN & 34 & 13 & 5.4 & 1.9 & 0.020 & 0.006 & 0.23 & 0.03 & 0.38 & 0.05 & 0.07 & 0.01 & 0.008 & 0.001 & 35 & 3 & 41 & \\
\hline JUL & 20 & 9 & 3.1 & 1.3 & 0.008 & 0.003 & 0.11 & 0.02 & 0.26 & 0.04 & 0.05 & 0.01 & 0.008 & 0.002 & 19 & 2 & 33 & \\
\hline AUG & 32 & 19 & 4.4 & 2.3 & 0.005 & 0.002 & 0.13 & 0.02 & 0.24 & 0.04 & 0.05 & 0.01 & 0.010 & 0.002 & 20 & 2 & 41 & \\
\hline SEP & 77 & 50 & 10.2 & 5.6 & 0.006 & 0.002 & 0.21 & 0.03 & 0.25 & 0.04 & 0.07 & 0.02 & 0.015 & 0.004 & 27 & 3 & 46 & \\
\hline Total & 935 & 526 & 134.6 & 64.8 & 0.228 & 0.085 & 5.84 & 0.96 & 15.59 & 2.65 & 1.64 & 0.37 & 0.277 & 0.077 & 1189 & 112 & 688 & \\
\hline
\end{tabular}

\section{Water year 1998}

\begin{tabular}{|c|c|c|c|c|c|c|c|c|c|c|c|c|c|c|c|c|c|}
\hline OCT & 59 & 26 & 9.7 & 3.8 & 0.008 & 0.003 & 0.24 & 0.03 & 0.29 & 0.04 & 0.06 & 0.01 & 0.013 & 0.003 & 34 & 3 & 46 \\
\hline NOV & 63 & 29 & 11.7 & 4.9 & 0.016 & 0.006 & 0.42 & 0.06 & 0.61 & 0.10 & 0.08 & 0.01 & 0.019 & 0.004 & 70 & 6 & 58 \\
\hline DEC & 35 & 17 & 7.7 & 3.4 & 0.021 & 0.008 & 0.36 & 0.05 & 0.59 & 0.09 & 0.05 & 0.01 & 0.010 & 0.002 & 100 & 8 & 51 \\
\hline JAN & 395 & 265 & 58.0 & 32.1 & 0.118 & 0.055 & 1.87 & 0.34 & 3.84 & 0.68 & 0.66 & 0.23 & 0.110 & 0.046 & 382 & 42 & 108 \\
\hline FEB & 128 & 63 & 20.1 & 8.9 & 0.037 & 0.012 & 0.72 & 0.09 & 3.51 & 0.48 & 0.12 & 0.02 & 0.023 & 0.005 & 264 & 23 & 72 \\
\hline MAR & 111 & 55 & 16.4 & 7.4 & 0.032 & 0.010 & 0.89 & 0.11 & 4.23 & 0.56 & 0.14 & 0.02 & 0.021 & 0.004 & 270 & 22 & 90 \\
\hline APR & 14 & 7 & 2.5 & 1.1 & 0.009 & 0.003 & 0.20 & 0.02 & 0.46 & 0.06 & 0.02 & 0.00 & 0.002 & 0.000 & 61 & 5 & 36 \\
\hline MAY & 13 & 6 & 2.4 & 1.1 & 0.013 & 0.004 & 0.14 & 0.02 & 0.13 & 0.02 & 0.02 & 0.00 & 0.002 & 0.000 & 28 & 2 & 27 \\
\hline JUN & 78 & 40 & 11.1 & 4.8 & 0.027 & 0.009 & 0.30 & 0.04 & 0.47 & 0.08 & 0.11 & 0.02 & 0.017 & 0.005 & 37 & 4 & 45 \\
\hline JUL & 461 & 290 & 48.4 & 25.8 & 0.060 & 0.029 & 1.02 & 0.20 & 1.99 & 0.42 & 0.89 & 0.25 & 0.160 & 0.057 & 75 & 9 & 91 \\
\hline AUG & 114 & 67 & 14.0 & 7.2 & 0.009 & 0.003 & 0.27 & 0.04 & 0.40 & 0.06 & 0.10 & 0.02 & 0.026 & 0.006 & 31 & 3 & 58 \\
\hline SEP & 106 & 48 & 15.4 & 6.4 & 0.008 & 0.002 & 0.25 & 0.03 & 0.25 & 0.03 & 0.07 & 0.01 & 0.017 & 0.003 & 34 & 3 & 60 \\
\hline Total & 1577 & 913 & 217.4 & 106.9 & 0.358 & 0.144 & 6.68 & 1.03 & 16.77 & 2.62 & 2.32 & 0.60 & 0.420 & 0.135 & 1386 & 130 & 742 \\
\hline
\end{tabular}

\section{Water year 1999}

\begin{tabular}{|c|c|c|c|c|c|c|c|c|c|c|c|c|c|c|c|c|c|}
\hline \multirow[t]{2}{*}{ OCT } & 28 & 17 & 4.9 & 2.6 & 0.004 & 0.001 & 0.09 & 0.01 & 0.08 & 0.01 & 0.02 & 0.00 & 0.005 & 0.001 & 16 & 2 & 26 \\
\hline & 4 & 3 & 1.2 & 0.8 & 0.004 & 0.001 & 0.05 & 0.01 & 0.05 & 0.01 & 0.01 & 0.00 & 0.002 & 0.000 & 13 & 1 & 15 \\
\hline DEC & 7 & 4 & 1.7 & 1.1 & 0.007 & 0.003 & 0.08 & 0.01 & 0.09 & 0.02 & 0.01 & 0.00 & 0.002 & 0.000 & 28 & 3 & 18 \\
\hline JAN & 214 & 163 & 32.8 & 20.9 & 0.057 & 0.027 & 0.76 & 0.14 & 1.72 & 0.34 & 0.18 & 0.06 & 0.038 & 0.016 & 195 & 25 & 55 \\
\hline FEB & 84 & 43 & 15.2 & 7.1 & 0.028 & 0.009 & 0.41 & 0.05 & 1.43 & 0.18 & 0.05 & 0.01 & 0.012 & 0.002 & 169 & 16 & 51 \\
\hline MAR & 150 & 81 & 22.2 & 10.8 & 0.038 & 0.012 & 0.95 & 0.12 & 3.54 & 0.47 & 0.15 & 0.02 & 0.024 & 0.005 & 260 & 23 & 91 \\
\hline APR & 26 & 14 & 4.7 & 2.4 & 0.014 & 0.004 & 0.29 & 0.03 & 0.47 & 0.06 & 0.03 & 0.00 & 0.003 & 0.001 & 73 & 6 & 44 \\
\hline MAY & 26 & 15 & 4.8 & 2.6 & 0.019 & 0.006 & 0.22 & 0.03 & 0.18 & 0.03 & 0.03 & 0.00 & 0.003 & 0.001 & 38 & 4 & 36 \\
\hline JUN & 33 & 16 & 5.9 & 2.6 & 0.019 & 0.006 & 0.15 & 0.02 & 0.16 & 0.02 & 0.04 & 0.01 & 0.006 & 0.001 & 24 & 2 & 32 \\
\hline JUL & 34 & 16 & 5.7 & 2.5 & 0.011 & 0.003 & 0.12 & 0.02 & 0.18 & 0.03 & 0.04 & 0.01 & 0.010 & 0.002 & 18 & 2 & 33 \\
\hline AUG & 39 & 25 & 5.8 & 3.3 & 0.005 & 0.002 & 0.10 & 0.01 & 0.12 & 0.02 & 0.03 & 0.01 & 0.009 & 0.002 & 15 & 1 & 34 \\
\hline SEP & 45 & 27 & 7.3 & 4.0 & 0.004 & 0.002 & 0.10 & 0.01 & 0.08 & 0.01 & 0.03 & 0.00 & 0.007 & 0.001 & 15 & 2 & 33 \\
\hline Total & 690 & 424 & 112.2 & 60.7 & 0.210 & 0.076 & 3.32 & 0.46 & 8.10 & 1.20 & 0.62 & 0.12 & 0.121 & 0.032 & 864 & 87 & 468 \\
\hline
\end{tabular}


Appendix. (continued) Estimated monthly loads and associated error for nine constituents at four sites in the Irondequoit Creek basin and at four sites in western Monroe County, N.Y., water years 1997-99.

\begin{tabular}{|c|c|c|c|c|c|c|c|c|c|c|c|}
\hline \multirow[b]{2}{*}{ Month } & \multirow{2}{*}{$\begin{array}{c}\text { Total } \\
\text { suspended } \\
\text { solids }\end{array}$} & $\begin{array}{c}\text { Volatile } \\
\text { suspended } \\
\text { solids }\end{array}$ & $\begin{array}{c}\text { Ammonia } \\
\text { nitrogen as } \\
\mathrm{N} \text {, dissolved }\end{array}$ & $\begin{array}{c}\text { Ammonia }+ \\
\text { organic } \\
\text { nitrogen as } \\
\mathrm{N}, \text { total }\end{array}$ & $\begin{array}{c}\text { Nitrite + } \\
\text { nitrate as } \mathrm{N}, \\
\text { total }\end{array}$ & $\begin{array}{c}\text { Total } \\
\text { phosphaous, } \\
\text { as P }\end{array}$ & \multicolumn{2}{|c|}{$\begin{array}{c}\text { Ortho- } \\
\text { phosphate } \\
\text { as P, } \\
\text { dissolved }\end{array}$} & \multicolumn{2}{|c|}{$\begin{array}{l}\text { Chloride, } \\
\text { dissolved }\end{array}$} & $\begin{array}{c}\text { Sulfate, } \\
\text { dissolved }\end{array}$ \\
\hline & & Load Error & Load Error & Load Error & Load Error & Load Error & Load & Error & Load & Error & Load Error \\
\hline
\end{tabular}

Allen Creek near Rochester (04232050)

Water year 1997

\begin{tabular}{|c|c|c|c|c|c|c|c|c|c|c|c|c|c|c|c|c|c|}
\hline OCT & 295 & 221 & 66.2 & 38.2 & 0.070 & 0.026 & 2.45 & 0.69 & 2.88 & 0.47 & 0.73 & 0.26 & 0.160 & 0.039 & 307 & 44 & 145 \\
\hline $\mathrm{NOV}$ & 120 & 87 & 24.2 & 13.8 & 0.043 & 0.014 & 1.76 & 0.52 & 2.52 & 0.43 & 0.30 & 0.08 & 0.090 & 0.016 & 368 & 43 & 134 \\
\hline DEC & 250 & 172 & 38.0 & 21.1 & 0.064 & 0.022 & 2.77 & 0.78 & 4.50 & 0.74 & 0.42 & 0.11 & 0.096 & 0.019 & 788 & 88 & 195 \\
\hline JAN & 103 & 59 & 15.7 & 6.7 & 0.032 & 0.009 & 1.28 & 0.30 & 2.15 & 0.28 & 0.10 & 0.02 & 0.019 & 0.003 & 531 & 57 & 90 \\
\hline FEB & 222 & 164 & 29.8 & 16.8 & 0.053 & 0.016 & 2.21 & 0.64 & 3.86 & 0.62 & 0.19 & 0.05 & 0.027 & 0.005 & 745 & 92 & 116 \\
\hline MAR & 253 & 170 & 33.6 & 18.5 & 0.066 & 0.019 & 3.19 & 0.79 & 5.94 & 0.83 & 0.25 & 0.04 & 0.026 & 0.003 & 1078 & 113 & 203 \\
\hline APR & 78 & 47 & 12.7 & 6.0 & 0.030 & 0.008 & 1.27 & 0.28 & 2.32 & 0.29 & 0.09 & 0.02 & 0.008 & 0.001 & 481 & 52 & 116 \\
\hline MAY & 62 & 40 & 14.2 & 6.7 & 0.035 & 0.010 & 1.01 & 0.24 & 1.40 & 0.19 & 0.10 & 0.02 & 0.010 & 0.001 & 253 & 29 & 84 \\
\hline JUN & 93 & 51 & 19.9 & 8.3 & 0.047 & 0.014 & 1.23 & 0.30 & 1.36 & 0.19 & 0.18 & 0.03 & 0.029 & 0.004 & 182 & 21 & 78 \\
\hline JUL & 54 & 39 & 8.9 & 4.6 & 0.023 & 0.008 & 0.52 & 0.16 & 0.65 & 0.11 & 0.14 & 0.03 & 0.025 & 0.004 & 87 & 11 & 46 \\
\hline AUG & 168 & 139 & 20.2 & 11.9 & 0.018 & 0.005 & 0.59 & 0.18 & 0.66 & 0.10 & 0.18 & 0.05 & 0.021 & 0.004 & 97 & 13 & 56 \\
\hline SEP & 233 & 194 & 41.1 & 25.6 & 0.026 & 0.009 & 0.92 & 0.26 & 1.00 & 0.15 & 0.27 & 0.09 & 0.041 & 0.010 & 137 & 19 & 79 \\
\hline Total & 931 & 1383 & 24.5 & 78.2 & 0.507 & 0.160 & 9.20 & 5.14 & 29.24 & 4.40 & 2.95 & 0.80 & 0.552 & 0.109 & 5054 & 582 & 342 \\
\hline
\end{tabular}

Water year 1998

\begin{tabular}{|c|c|c|c|c|c|c|c|c|c|c|c|c|c|c|c|c|c|}
\hline OCT & 52 & 33 & 12.3 & 5.7 & 0.018 & 0.005 & 0.56 & 0.13 & 0.75 & 0.10 & 0.11 & 0.02 & 0.032 & 0.005 & 121 & 14 & 64 \\
\hline NOV & 86 & 61 & 16.2 & 9.4 & 0.030 & 0.008 & 1.11 & 0.30 & 1.80 & 0.29 & 0.19 & 0.04 & 0.064 & 0.009 & 303 & 34 & 121 \\
\hline DEC & 112 & 77 & 16.1 & 9.0 & 0.031 & 0.008 & 1.21 & 0.28 & 2.23 & 0.31 & 0.14 & 0.02 & 0.037 & 0.005 & 503 & 52 & 130 \\
\hline JAN & 1410 & 938 & 168.9 & 92.1 & 0.242 & 0.115 & 5.02 & 1.21 & 11.41 & 1.99 & 2.24 & 1.07 & 0.317 & 0.108 & 1687 & 244 & 330 \\
\hline FEB & 476 & 321 & 54.6 & 29.4 & 0.076 & 0.020 & 3.01 & 0.72 & 5.68 & 0.77 & 0.32 & 0.07 & 0.047 & 0.007 & 1058 & 117 & 185 \\
\hline MAR & 471 & 342 & 52.8 & 31.3 & 0.085 & 0.023 & 3.35 & 0.71 & 7.14 & 0.88 & 0.40 & 0.08 & 0.044 & 0.007 & 1221 & 128 & 257 \\
\hline APR & 59 & 41 & 8.9 & 4.8 & 0.021 & 0.005 & 0.72 & 0.14 & 1.53 & 0.17 & 0.07 & 0.01 & 0.006 & 0.001 & 347 & 36 & 95 \\
\hline MAY & 70 & 55 & 13.0 & 7.0 & 0.028 & 0.007 & 0.68 & 0.16 & 1.12 & 0.15 & 0.08 & 0.02 & 0.009 & 0.001 & 211 & 25 & 77 \\
\hline JUN & 481 & 334 & 62.1 & 31.8 & 0.073 & 0.026 & 1.71 & 0.49 & 2.01 & 0.33 & 0.54 & 0.17 & 0.084 & 0.019 & 210 & 28 & 107 \\
\hline JUL & 2185 & 1308 & 244.4 & 115.4 & 0.234 & 0.101 & 4.61 & 1.36 & 5.97 & 1.09 & 3.68 & 1.31 & 0.492 & 0.126 & 448 & 64 & 264 \\
\hline AUG & 1328 & 933 & 126.3 & 68.2 & 0.054 & 0.018 & 1.74 & 0.46 & 2.04 & 0.30 & 0.94 & 0.32 & 0.098 & 0.023 & 234 & 32 & 153 \\
\hline SEP & 464 & 259 & 62.1 & 25.1 & 0.029 & 0.007 & 1.07 & 0.23 & 1.19 & 0.14 & 0.31 & 0.06 & 0.045 & 0.006 & 177 & 20 & 115 \\
\hline Total & 7194 & 4702 & 837.7 & 429.2 & 0.921 & 0.343 & 24.79 & 6.19 & 42.87 & 6.52 & 9.02 & 3.19 & 1.275 & 0.317 & 6520 & 794 & 1898 \\
\hline
\end{tabular}

\section{Water year 1999}

\begin{tabular}{|c|c|c|c|c|c|c|c|c|c|c|c|c|c|c|c|c|c|c|}
\hline OCT & 91 & 65 & 18.3 & 9.3 & 0.020 & 0.005 & 0.56 & 0.14 & 0.81 & 0.11 & 0.14 & 0.03 & 0.040 & 0.006 & 135 & 15 & 81 & 4 \\
\hline NOV & 10 & 9 & 2.4 & 1.7 & 0.010 & 0.003 & 0.21 & 0.06 & 0.49 & 0.09 & 0.05 & 0.01 & 0.021 & 0.003 & 108 & 14 & 49 & \\
\hline DEC & 21 & 22 & 3.0 & 2.3 & 0.010 & 0.003 & 0.22 & 0.06 & 0.58 & 0.09 & 0.04 & 0.01 & 0.012 & 0.002 & 164 & 22 & 48 & \\
\hline JAN & 913 & 778 & 90.4 & 60.5 & 0.096 & 0.043 & 2.11 & 0.64 & 5.02 & 0.95 & 0.69 & 0.30 & 0.105 & 0.032 & 823 & 142 & 166 & 14 \\
\hline FEB & 317 & 221 & 33.6 & 18.8 & 0.043 & 0.011 & 1.51 & 0.35 & 3.11 & 0.40 & 0.16 & 0.03 & 0.030 & 0.005 & 684 & 81 & 131 & \\
\hline MAR & 490 & 406 & 49.3 & 33.6 & 0.075 & 0.021 & 2.52 & 0.51 & 6.24 & 0.76 & 0.41 & 0.10 & 0.045 & 0.007 & 1092 & 124 & 261 & 15 \\
\hline APR & 104 & 75 & 13.5 & 7.8 & 0.024 & 0.006 & 0.77 & 0.14 & 1.75 & 0.18 & 0.09 & 0.02 & 0.008 & 0.001 & 392 & 42 & 122 & 6 \\
\hline MAY & 87 & 55 & 14.8 & 7.2 & 0.028 & 0.007 & 0.63 & 0.14 & 1.10 & 0.14 & 0.09 & 0.02 & 0.010 & 0.002 & 216 & 25 & 90 & \\
\hline JUN & 75 & 41 & 13.0 & 5.5 & 0.029 & 0.008 & 0.52 & 0.12 & 0.79 & 0.10 & 0.12 & 0.02 & 0.024 & 0.003 & 120 & 14 & 65 & \\
\hline JUL & 47 & 27 & 7.4 & 3.4 & 0.018 & 0.006 & 0.31 & 0.08 & 0.50 & 0.07 & 0.12 & 0.02 & 0.025 & 0.004 & 75 & 10 & 49 & \\
\hline AUG & 305 & 202 & 29.6 & 14.0 & 0.019 & 0.005 & 0.52 & 0.12 & 0.72 & 0.09 & 0.21 & 0.05 & 0.030 & 0.005 & 113 & 14 & 82 & \\
\hline SEP & 366 & 212 & 46.3 & 20.2 & 0.021 & 0.006 & 0.64 & 0.15 & 0.84 & 0.11 & 0.23 & 0.05 & 0.037 & 0.006 & 134 & 16 & 99 & 6 \\
\hline Total & 2826 & 2113 & 321.6 & 184.3 & 0.393 & 0.124 & 10.52 & 2.51 & 21.95 & 3.09 & 2.35 & 0.66 & 0.387 & 0.076 & 4056 & 519 & 1243 & \\
\hline
\end{tabular}


Appendix. (continued) Estimated monthly loads and associated error for nine constituents at four sites in the Irondequoit Creek basin and at four sites in western Monroe County, N.Y., water years 1997-99.

\begin{tabular}{|c|c|c|c|c|c|c|c|c|c|}
\hline & $\begin{array}{l}\text { Total } \\
\text { suspended } \\
\text { solids }\end{array}$ & $\begin{array}{l}\text { Volatile } \\
\text { suspended } \\
\text { solids }\end{array}$ & $\begin{array}{c}\text { Ammonia } \\
\text { nitrogen as } \\
\mathrm{N} \text {, dissolved }\end{array}$ & $\begin{array}{c}\text { Ammonia }+ \\
\text { organic } \\
\text { nitrogen as } \\
\mathrm{N}, \text { total }\end{array}$ & $\begin{array}{l}\text { Nitrite }+ \\
\text { nitrate as } \mathrm{N}, \\
\text { total }\end{array}$ & $\begin{array}{c}\text { Total } \\
\text { phosphaous, } \\
\text { as P }\end{array}$ & $\begin{array}{c}\text { Ortho- } \\
\text { phosphate } \\
\text { as P, } \\
\text { dissolved }\end{array}$ & & $\begin{array}{l}\text { Sulfate, } \\
\text { dissolved }\end{array}$ \\
\hline Month & Load Error & Load Error & Load Error & Load Error & Load Error & Load Error & Load Error & Load Error & Load Error \\
\hline
\end{tabular}

\section{Irondequoit Creek at Blossom Road (0423205010)}

Water year 1997

\begin{tabular}{|c|c|c|c|c|c|c|c|c|c|c|c|c|c|c|c|c|c|c|}
\hline OCT & 6556 & 6293 & 642 & 492 & 0.158 & 0.078 & 15.01 & 3.34 & 12.45 & 0.62 & 6.51 & 2.71 & 0.296 & 0.049 & 1413 & 92 & 1717 & 134 \\
\hline NOV & 1301 & 997 & 165 & 107 & 0.133 & 0.043 & 10.02 & 1.57 & 14.16 & 0.56 & 2.13 & 0.65 & 0.206 & 0.026 & 1699 & 91 & 1678 & 114 \\
\hline DEC & 2038 & 1509 & 249 & 152 & 0.344 & 0.103 & 15.20 & 2.27 & 23.38 & 0.90 & 3.10 & 0.89 & 0.257 & 0.029 & 2689 & 140 & 1992 & 134 \\
\hline JAN & 597 & 242 & 88 & 32 & 0.143 & 0.033 & 5.06 & 0.57 & 14.64 & 0.53 & 0.65 & 0.11 & 0.092 & 0.009 & 1767 & 87 & 1212 & 77 \\
\hline FEB & 1712 & 887 & 175 & 74 & 0.146 & 0.042 & 7.76 & 1.08 & 17.50 & 0.69 & 1.31 & 0.31 & 0.101 & 0.011 & 2101 & 113 & 1245 & 85 \\
\hline MAR & 2197 & 795 & 227 & 72 & 0.228 & 0.051 & 13.42 & 1.40 & 24.79 & 0.85 & 1.81 & 0.28 & 0.113 & 0.010 & 3071 & 147 & 1820 & 113 \\
\hline APR & 810 & 333 & 104 & 36 & 0.165 & 0.037 & 7.33 & 0.82 & 13.59 & 0.49 & 0.80 & 0.13 & 0.053 & 0.005 & 1738 & 87 & 1374 & 87 \\
\hline MAY & 757 & 367 & 113 & 47 & 0.148 & 0.036 & 5.65 & 0.69 & 9.26 & 0.34 & & & & 0.007 & 1059 & 53 & 200 & 77 \\
\hline JUN & 1055 & 402 & 145 & 49 & 0.105 & 0.025 & 5.10 & 0.59 & 7.99 & 0.30 & 1.23 & 0.21 & 0.120 & 0.012 & 816 & 41 & 1042 & 67 \\
\hline JUL & 725 & 297 & 90 & 33 & 0.044 & 0.010 & 2.21 & 0.25 & 4.38 & 0.16 & 0.57 & 0.09 & 0.076 & 0.008 & 478 & 24 & 690 & 45 \\
\hline AUG & 796 & 374 & 107 & 44 & 0.039 & 0.010 & 1.99 & 0.26 & 3.99 & 0.16 & 0.53 & 0.11 & 0.071 & 0.008 & 474 & 25 & 726 & 48 \\
\hline SEP & 1434 & 1093 & 193 & 116 & 0.054 & 0.020 & 3.67 & 0.74 & 5.23 & 0.24 & 1.34 & 0.51 & 0.125 & 0.020 & 644 & 39 & 1004 & 71 \\
\hline Total & 978 & 5889 & 298 & 255 & 1.707 & 0.488 & 2.42 & .58 & 51.36 & 5.84 & 0.91 & 6.20 & 1.580 & 0.194 & 8949 & 939 & 700 & \\
\hline
\end{tabular}

\section{Water year 1998}

\begin{tabular}{lrrrrrrrrrrrrrrrrrr} 
OCT & 359 & 169 & 59 & 60 & 0.035 & 0.008 & 2.35 & 0.27 & 4.80 & 0.17 & 0.47 & 0.08 & 0.086 & 0.009 & 654 & 32 & 1014 & 64 \\
NOV & 377 & 213 & 59 & 59 & 0.088 & 0.021 & 4.66 & 0.54 & 9.39 & 0.34 & 0.81 & 0.15 & 0.146 & 0.015 & 1239 & 62 & 1344 & 86 \\
DEC & 391 & 193 & 63 & 63 & 0.171 & 0.037 & 5.15 & 0.53 & 13.39 & 0.46 & 0.75 & 0.11 & 0.139 & 0.012 & 1724 & 83 & 1421 & 88 \\
JAN & 42121 & 39309 & 2649 & 2118 & 2.158 & 1.093 & 40.65 & 9.63 & 39.58 & 1.85 & 27.03 & 11.73 & 0.608 & 0.086 & 4370 & 268 & 2621 & 201 \\
FEB & 2951 & 1340 & 287 & 106 & 0.272 & 0.069 & 11.17 & 1.36 & 23.41 & 0.86 & 2.56 & 0.51 & 0.197 & 0.020 & 2854 & 144 & 1652 & 106 \\
MAR & 3489 & 1325 & 328 & 104 & 0.361 & 0.084 & 15.69 & 1.70 & 26.65 & 0.92 & 3.10 & 0.53 & 0.176 & 0.016 & 3402 & 162 & 2043 & 125 \\
APR & 621 & 222 & 83 & 26 & 0.174 & 0.038 & 5.56 & 0.59 & 11.33 & 0.39 & 0.72 & 0.12 & 0.057 & 0.005 & 1540 & 74 & 1301 & 80 \\
MAY & 552 & 233 & 84 & 31 & 0.151 & 0.036 & 4.10 & 0.49 & 7.51 & 0.27 & 0.74 & 0.14 & 0.065 & 0.006 & 927 & 46 & 1107 & 69 \\
JUN & 1737 & 1035 & 200 & 94 & 0.129 & 0.037 & 5.17 & 0.81 & 7.25 & 0.30 & 2.21 & 0.64 & 0.187 & 0.027 & 759 & 41 & 1005 & 66 \\
JUL & 15598 & 13852 & 1188 & 807 & 0.348 & 0.154 & 16.23 & 3.24 & 14.03 & 0.65 & 14.11 & 5.47 & 0.620 & 0.092 & 1336 & 81 & 1533 & 113 \\
AUG & 1929 & 1185 & 236 & 116 & 0.083 & 0.025 & 3.71 & 0.58 & 6.08 & 0.24 & 1.61 & 0.47 & 0.179 & 0.023 & 713 & 38 & 1013 & 66 \\
SEP & 856 & 349 & 131 & 46 & 0.054 & 0.013 & 2.57 & 0.29 & 4.98 & 0.18 & 0.82 & 0.15 & 0.133 & 0.013 & 651 & 32 & 1058 & 67 \\
\hline Total & 70981 & 59425 & 5368 & 3631 & 4.024 & 1.615 & 117.01 & 20.03 & 168.4 & 6.63 & 54.93 & 20.10 & 2.593 & 0.324 & 20169 & 1063 & 17112 & 1131
\end{tabular}

Water year 1999

\begin{tabular}{lrrrrrrrrrrrrrrrrrr} 
OCT & 353 & 177 & 58 & 26 & 0.041 & 0.010 & 2.09 & 0.24 & 4.48 & 0.16 & 0.53 & 0.10 & 0.107 & 0.011 & 643 & 32 & 1039 & 66 \\
NOV & 102 & 59 & 17 & 10 & 0.044 & 0.010 & 1.39 & 0.15 & 4.08 & 0.15 & 0.22 & 0.03 & 0.059 & 0.006 & 627 & 32 & 835 & 55 \\
DEC & 121 & 64 & 20 & 11 & 0.087 & 0.020 & 1.57 & 0.18 & 5.64 & 0.21 & 0.23 & 0.04 & 0.057 & 0.006 & 840 & 43 & 844 & 56 \\
JAN & 6228 & 6271 & 488 & 392 & 0.526 & 0.272 & 10.08 & 2.42 & 16.09 & 0.84 & 5.33 & 2.40 & 0.248 & 0.042 & 1995 & 134 & 1349 & 105 \\
FEB & 1221 & 474 & 138 & 47 & 0.199 & 0.050 & 5.69 & 0.67 & 15.68 & 0.60 & 1.34 & 0.24 & 0.160 & 0.017 & 2069 & 108 & 1319 & 88 \\
MAR & 3712 & 1655 & 332 & 121 & 0.451 & 0.118 & 14.31 & 1.72 & 24.13 & 0.89 & 3.69 & 0.72 & 0.209 & 0.021 & 3245 & 164 & 2036 & 132 \\
APR & 694 & 250 & 92 & 30 & 0.236 & 0.054 & 5.66 & 0.61 & 11.60 & 0.41 & 0.95 & 0.15 & 0.080 & 0.007 & 1637 & 80 & 1421 & 90 \\
MAY & 563 & 205 & 86 & 29 & 0.192 & 0.043 & 4.01 & 0.43 & 7.74 & 0.28 & 0.89 & 0.14 & 0.093 & 0.009 & 993 & 49 & 1211 & 77 \\
JUN & 606 & 226 & 82 & 27 & 0.098 & 0.022 & 2.45 & 0.26 & 4.90 & 0.17 & 0.84 & 0.13 & 0.117 & 0.011 & 577 & 29 & 859 & 55 \\
JUL & 633 & 253 & 78 & 29 & 0.060 & 0.013 & 1.68 & 0.18 & 3.74 & 0.13 & 0.65 & 0.10 & 0.110 & 0.010 & 453 & 22 & 708 & 45 \\
AUG & 761 & 303 & 102 & 36 & 0.059 & 0.013 & 1.72 & 0.19 & 3.84 & 0.14 & 0.67 & 0.11 & 0.118 & 0.012 & 501 & 25 & 807 & 51 \\
SEP & 659 & 285 & 102 & 39 & 0.055 & 0.014 & 1.90 & 0.23 & 3.99 & 0.15 & 0.73 & 0.14 & 0.134 & 0.015 & 559 & 29 & 973 & 65 \\
\hline Total & 15653 & 10222 & 1596 & 797 & 2.048 & 0.639 & 52.55 & 7.28 & 105.91 & 4.13 & 16.07 & 4.30 & 1.492 & 0.167 & 14139 & 747 & 13401 & 885
\end{tabular}


Appendix. (continued) Estimated monthly loads and associated error for nine constituents at four sites in the Irondequoit Creek basin and at four sites in western Monroe County, N.Y., water years 1997-99.

\begin{tabular}{|c|c|c|c|c|c|c|c|c|c|}
\hline & $\begin{array}{c}\text { Total } \\
\text { suspended } \\
\text { solids }\end{array}$ & $\begin{array}{l}\text { Volatile } \\
\text { suspended } \\
\text { solids }\end{array}$ & $\begin{array}{c}\text { Ammonia } \\
\text { nitrogen as } \\
\mathrm{N} \text {, dissolved }\end{array}$ & $\begin{array}{c}\text { Ammonia }+ \\
\text { organic } \\
\text { nitrogen as } \\
\mathrm{N}, \text { total }\end{array}$ & $\begin{array}{l}\text { Nitrite }+ \\
\text { nitrate as } N \text {, } \\
\text { total }\end{array}$ & $\begin{array}{c}\text { Total } \\
\text { phosphaous, } \\
\text { as P }\end{array}$ & $\begin{array}{c}\text { Ortho- } \\
\text { phosphate } \\
\text { as P, } \\
\text { dissolved }\end{array}$ & $\begin{array}{l}\text { Chloride, } \\
\text { dissolved }\end{array}$ & $\begin{array}{l}\text { Sulfate, } \\
\text { dissolved }\end{array}$ \\
\hline Month & Load Error & Load Error & Load Error & Load Error & Load Error & Load Error & Load Error & Load Error & Load Error \\
\hline
\end{tabular}

\section{Northrup Creek at North Greece (0422026250)}

\section{Water year 1997}

\begin{tabular}{|c|c|c|c|c|c|c|c|c|c|c|c|c|c|c|c|c|c|}
\hline \multirow{2}{*}{$\begin{array}{l}\text { OCT } \\
\text { NOV }\end{array}$} & 220 & 125 & 33.4 & 12.7 & 0.059 & 0.014 & 1.82 & 0.32 & 2.68 & 0.24 & 0.99 & 0.33 & 0.285 & 0.053 & 122 & 11 & 106 \\
\hline & 51 & 34 & 12.0 & 6.3 & 0.173 & 0.032 & 1.71 & 0.19 & 2.58 & 0.16 & 0.32 & 0.06 & 0.111 & 0.012 & 162 & 10 & 108 \\
\hline DEC & 25 & 25 & 7.3 & 5.6 & 0.487 & 0.087 & 1.85 & 0.20 & 2.90 & 0.18 & 0.25 & 0.04 & 0.082 & 0.009 & 226 & 14 & 107 \\
\hline JAN & 94 & 64 & 14.2 & 7.6 & 0.692 & 0.126 & 1.62 & 0.17 & 2.53 & 0.15 & 0.22 & 0.03 & 0.075 & 0.007 & 210 & 13 & 75 \\
\hline FEB & 269 & 110 & 28.0 & 8.3 & 0.774 & 0.147 & 2.28 & 0.26 & 2.93 & 0.18 & 0.30 & 0.05 & 0.066 & 0.007 & 259 & 17 & 84 \\
\hline MAR & 122 & 55 & 16.3 & 5.5 & 0.441 & 0.076 & 2.09 & 0.20 & 2.92 & 0.16 & 0.20 & 0.03 & 0.032 & 0.003 & 273 & 16 & 85 \\
\hline APR & 28 & 12 & 5.3 & 1.7 & 0.083 & 0.017 & 0.83 & 0.09 & 1.58 & 0.09 & 0.10 & 0.01 & 0.021 & 0.002 & 118 & 8 & 40 \\
\hline MAY & 41 & 18 & 8.0 & 2.5 & 0.025 & 0.005 & 0.73 & 0.08 & 1.33 & 0.09 & 0.22 & 0.03 & 0.074 & 0.008 & 63 & 4 & 34 \\
\hline JUN & 50 & 20 & 8.7 & 2.7 & 0.020 & 0.004 & 0.73 & 0.08 & 1.19 & 0.07 & 0.30 & 0.04 & 0.119 & 0.012 & 45 & 3 & 34 \\
\hline JUL & 16 & 8 & 2.7 & 1.0 & 0.007 & 0.001 & 0.29 & 0.03 & 0.70 & 0.05 & 0.15 & 0.02 & 0.066 & 0.008 & 19 & 1 & 19 \\
\hline AUG & 37 & 14 & 5.3 & 1.5 & 0.006 & 0.001 & 0.28 & 0.03 & 0.77 & 0.05 & 0.17 & 0.02 & 0.065 & 0.007 & 24 & 2 & 25 \\
\hline SEP & 119 & 51 & 15.5 & 4.8 & 0.008 & 0.002 & 0.37 & 0.05 & 0.93 & 0.06 & 0.23 & 0.04 & 0.107 & 0.012 & 32 & 2 & 35 \\
\hline Total & 1072 & 536 & 156.7 & 60.2 & 2.775 & 0.512 & 14.60 & 1.70 & 23.04 & 1.48 & 3.45 & 0.70 & 1.103 & 0.140 & 1553 & 101 & 752 \\
\hline
\end{tabular}

\section{Water year 1998}

\begin{tabular}{|c|c|c|c|c|c|c|c|c|c|c|c|c|c|c|c|c|c|}
\hline OCT & 48 & 25 & 8.3 & 3.3 & 0.011 & 0.002 & 0.33 & 0.04 & 0.87 & 0.06 & 0.12 & 0.02 & 0.081 & 0.009 & 32 & 2 & 31 \\
\hline NOV & 43 & 35 & 11.3 & 7.4 & 0.165 & 0.032 & 1.31 & 0.13 & 2.16 & 0.13 & 0.22 & 0.03 & 0.087 & 0.008 & 141 & 9 & 103 \\
\hline DEC & 40 & 42 & 10.8 & 8.9 & 0.496 & 0.087 & 1.68 & 0.16 & 2.78 & 0.16 & 0.23 & 0.03 & 0.081 & 0.007 & 223 & 13 & 118 \\
\hline JAN & 501 & 321 & 59.9 & 28.5 & 1.171 & 0.228 & 3.77 & 0.60 & 5.15 & 0.45 & 1.14 & 0.41 & 0.245 & 0.050 & 402 & 31 & 177 \\
\hline FEB & 462 & 184 & 43.7 & 12.5 & 0.700 & 0.127 & 2.10 & 0.22 & 2.82 & 0.17 & 0.29 & 0.05 & 0.068 & 0.007 & 248 & 15 & 94 \\
\hline MAR & 221 & 105 & 25.9 & 8.9 & 0.390 & 0.069 & 1.92 & 0.19 & 2.80 & 0.16 & 0.22 & 0.03 & 0.036 & 0.003 & 254 & 15 & 93 \\
\hline APR & 51 & 19 & 9.1 & 2.6 & 0.072 & 0.012 & 0.81 & 0.08 & 1.59 & 0.09 & 0.12 & 0.02 & 0.025 & 0.002 & 117 & 7 & 47 \\
\hline MAY & 118 & 40 & 20.3 & 4.9 & 0.044 & 0.008 & 1.10 & 0.12 & 1.82 & 0.11 & 0.33 & 0.05 & 0.095 & 0.009 & 102 & 7 & 59 \\
\hline JUN & 100 & 31 & 15.6 & 3.6 & 0.021 & 0.004 & 0.75 & 0.07 & 1.23 & 0.07 & 0.34 & 0.04 & 0.135 & 0.013 & 47 & 3 & 44 \\
\hline JUL & 138 & 44 & 18.7 & 4.2 & 0.024 & 0.005 & 0.88 & 0.10 & 1.35 & 0.08 & 0.44 & 0.07 & 0.132 & 0.014 & 51 & 3 & 61 \\
\hline AUG & 154 & 59 & 18.4 & 4.8 & 0.011 & 0.002 & 0.47 & 0.05 & 1.07 & 0.07 & 0.31 & 0.05 & 0.096 & 0.010 & 39 & 3 & 48 \\
\hline SEP & 217 & 83 & 26.4 & 7.6 & 0.008 & 0.002 & 0.39 & 0.04 & 0.99 & 0.06 & 0.26 & 0.04 & 0.119 & 0.012 & 36 & 2 & 45 \\
\hline Total & 2093 & 988 & 268.4 & 97.2 & 3.113 & 0.578 & 15.51 & 1.80 & 24.63 & 1.61 & 4.02 & 0.84 & 1.200 & 0.144 & 1692 & 110 & 920 \\
\hline
\end{tabular}

\section{Water year 1999}

\begin{tabular}{|c|c|c|c|c|c|c|c|c|c|c|c|c|c|c|c|c|c|}
\hline OCT & 110 & 63 & 17.3 & 7.6 & 0.013 & 0.003 & 0.38 & 0.04 & 0.96 & 0.06 & 0.15 & 0.02 & 0.097 & 0.010 & 37 & 3 & 43 \\
\hline $\mathrm{NOV}$ & 14 & 13 & 3.6 & 2.6 & 0.022 & 0.005 & 0.28 & 0.03 & 0.80 & 0.06 & 0.06 & 0.01 & 0.040 & 0.005 & 34 & 3 & 31 \\
\hline DEC & 3 & 4 & 1.1 & 1.0 & 0.033 & 0.009 & 0.17 & 0.03 & 0.71 & 0.07 & 0.03 & 0.01 & 0.026 & 0.004 & 30 & 3 & 18 \\
\hline JAN & 280 & 197 & 29.1 & 15.0 & 0.347 & 0.091 & 0.96 & 0.15 & 1.69 & 0.13 & 0.19 & 0.04 & 0.067 & 0.009 & 123 & 10 & 58 \\
\hline FEB & 300 & 158 & 29.3 & 11.6 & 0.335 & 0.070 & 0.92 & 0.11 & 1.59 & 0.10 & 0.13 & 0.02 & 0.042 & 0.005 & 126 & 9 & 55 \\
\hline MAR & 379 & 203 & 41.8 & 16.6 & 0.372 & 0.069 & 1.91 & 0.20 & 2.87 & 0.17 & 0.24 & 0.04 & 0.039 & 0.004 & 260 & 16 & 111 \\
\hline APR & 75 & 34 & 12.5 & 4.2 & 0.059 & 0.011 & 0.69 & 0.07 & 1.44 & 0.08 & 0.11 & 0.01 & 0.025 & 0.002 & 104 & 6 & 48 \\
\hline MAY & 190 & 62 & 30.3 & 7.3 & 0.037 & 0.007 & 0.98 & 0.10 & 1.70 & 0.11 & 0.32 & 0.04 & 0.100 & 0.010 & 93 & 6 & 64 \\
\hline JUN & 191 & 62 & 27.1 & 6.6 & 0.021 & 0.004 & 0.77 & 0.08 & 1.27 & 0.08 & 0.37 & 0.05 & 0.151 & 0.015 & 49 & 3 & 53 \\
\hline JUL & 155 & 54 & 20.3 & 5.3 & 0.016 & 0.003 & 0.61 & 0.06 & 1.12 & 0.07 & 0.32 & 0.04 & 0.113 & 0.012 & 40 & 3 & 55 \\
\hline AUG & 246 & 95 & 28.4 & 8.1 & 0.011 & 0.002 & 0.47 & 0.05 & 1.09 & 0.07 & 0.32 & 0.05 & 0.104 & 0.011 & 41 & 3 & 59 \\
\hline SEP & 483 & 230 & 54.2 & 19.5 & 0.010 & 0.002 & 0.46 & 0.05 & 1.13 & 0.08 & 0.33 & 0.05 & 0.146 & 0.016 & 43 & 3 & 63 \\
\hline Total & 2426 & 1175 & 295.0 & 105.4 & 1.276 & 0.276 & 8.60 & 0.97 & 16.37 & 1.08 & 2.57 & 0.38 & 0.950 & 0.103 & 980 & 68 & 658 \\
\hline
\end{tabular}


Appendix. (continued) Estimated monthly loads and associated error for nine constituents at four sites in the Irondequoit Creek basin and at four sites in western Monroe County, N.Y., water years 1997-99.

\begin{tabular}{|c|c|c|c|c|c|c|c|c|c|c|c|c|}
\hline \multirow[b]{2}{*}{ Month } & \multirow{2}{*}{$\begin{array}{c}\text { Total } \\
\text { suspended } \\
\text { solids }\end{array}$} & $\begin{array}{c}\text { Volatile } \\
\text { suspended } \\
\text { solids }\end{array}$ & $\begin{array}{c}\text { Ammonia } \\
\text { nitrogen as } \\
\mathrm{N} \text {, dissolved }\end{array}$ & $\begin{array}{c}\text { Ammonia }+ \\
\text { organic } \\
\text { nitrogen as } \\
\mathrm{N}, \text { total }\end{array}$ & $\begin{array}{c}\text { Nitrite }+ \\
\text { nitrate as } \mathrm{N} \\
\text { total }\end{array}$ & \multicolumn{2}{|c|}{$\begin{array}{c}\text { Total } \\
\text { phosphaous, } \\
\text { as P }\end{array}$} & \multicolumn{2}{|c|}{$\begin{array}{c}\text { Ortho- } \\
\text { phosphate } \\
\text { as P, } \\
\text { dissolved }\end{array}$} & \multicolumn{2}{|c|}{$\begin{array}{l}\text { Chloride, } \\
\text { dissolved }\end{array}$} & $\begin{array}{l}\text { Sulfate, } \\
\text { dissolved }\end{array}$ \\
\hline & & Load Error & Load Error & Load Error & Load Error & Load & Error & Load & Error & Load & Error & Load Error \\
\hline
\end{tabular}

\section{Oatka Creek at Garbutt (04230500)}

\begin{tabular}{|c|c|c|c|c|c|c|c|c|c|c|c|c|c|c|c|c|c|c|}
\hline \multicolumn{19}{|c|}{ Water year 1997} \\
\hline OCT & -- & -- & -- & -- & -- & -- & -- & -- & -- & -- & -- & -- & -- & -- & -- & -- & -- & -- \\
\hline NOV & -- & -- & -- & -- & -- & -- & -- & -- & -- & -- & -- & -- & -- & -- & -- & -- & -- & -- \\
\hline DEC & -- & -- & -- & -- & -- & -- & -- & -- & -- & -- & -- & -- & -- & -- & -- & -- & -- & -- \\
\hline JAN & -- & -- & -- & -- & -- & -- & -- & -- & -- & -- & -- & -- & -- & -- & -- & -- & -- & -- \\
\hline FEB & -- & -- & -- & -- & -- & -- & -- & -- & -- & -- & -- & -- & -- & -- & -- & -- & -- & -- \\
\hline MAR & -- & -- & -- & -- & -- & -- & -- & -- & -- & -- & -- & -- & -- & -- & -- & -- & -- & -- \\
\hline APR & -- & -- & -- & -- & -- & - & -- & -- & -- & -- & -- & -- & -- & -- & -- & -- & -- & -- \\
\hline MAY & -- & -- & -- & -- & -- & $\ldots$ & -- & -- & -- & -- & -- & -- & -- & -- & -- & -- & -- & -- \\
\hline JUN & -- & -- & -- & -- & -- & - & -- & -- & -- & -- & -- & -- & -- & -- & -- & -- & - & -- \\
\hline JUL & 91 & 30 & 34.4 & 15.0 & 0.072 & 0.011 & 1.78 & 0.20 & 7.42 & 0.25 & 0.18 & 0.02 & 0.033 & 0.004 & 221 & 6 & 1694 & 71 \\
\hline AUG & 48 & 16 & 14.9 & 6.6 & 0.035 & 0.005 & 1.06 & 0.11 & 4.67 & 0.15 & 0.09 & 0.01 & 0.017 & 0.002 & 176 & 5 & 1466 & 77 \\
\hline SEP & 65 & 25 & 19.3 & 8.8 & 0.026 & 0.005 & 1.20 & 0.17 & 5.09 & 0.20 & 0.12 & 0.02 & 0.026 & 0.006 & 197 & 6 & 1506 & 92 \\
\hline Total & 204 & 71 & 68.6 & 30.4 & 0.133 & 0.021 & 4.04 & 0.48 & 17.18 & 0.60 & 0.39 & 0.05 & 0.076 & 0.012 & 594 & 17 & 4666 & 240 \\
\hline
\end{tabular}

\section{Water year 1998}

\begin{tabular}{|c|c|c|c|c|c|c|c|c|c|c|c|c|c|c|c|c|c|c|}
\hline OCT & 151 & 46 & 67.7 & 26.0 & 0.045 & 0.008 & 2.5 & 0.31 & 9.46 & 0.34 & 0.27 & 0.04 & 0.068 & 0.010 & 330 & 9 & 1913 & 160 \\
\hline $\mathrm{NOV}$ & 1283 & 451 & 613.5 & 287.0 & 0.290 & 0.054 & 12.49 & 1.65 & 35.12 & 1.35 & 1.78 & 0.27 & 0.469 & 0.076 & 930 & 29 & 2868 & 163 \\
\hline DEC & 1713 & 548 & 564.3 & 247.8 & 0.764 & 0.123 & 15.95 & 1.86 & 54.18 & 1.89 & 2.25 & 0.30 & 0.614 & 0.086 & 1286 & 37 & 3252 & 189 \\
\hline JAN & 8434 & 4333 & 1080 & 564.0 & 5.071 & 1.599 & 54.32 & 12.13 & 145.5 & 7.36 & 11.75 & 3.35 & 3.738 & 1.118 & 2487 & 95 & 4564 & 265 \\
\hline FEB & 622 & 189 & 168.7 & 65.5 & 1.152 & 0.180 & 13.31 & 1.59 & 71.00 & 2.47 & 1.70 & 0.24 & 0.568 & 0.083 & 1304 & 37 & 3370 & 172 \\
\hline MAR & 903 & 314 & 289.1 & 123.4 & 1.313 & 0.219 & 22.91 & 2.91 & 99.90 & 3.57 & 2.94 & 0.44 & 0.683 & 0.105 & 1895 & 55 & 4616 & 237 \\
\hline APR & 394 & 103 & 121.2 & 38.9 & 0.439 & 0.065 & 10.80 & 1.21 & 48.59 & 1.60 & 1.16 & 0.15 & 0.182 & 0.025 & 1156 & 31 & 3660 & 179 \\
\hline MAY & 685 & 208 & 124.2 & 38.5 & 0.447 & 0.083 & 11.69 & 1.67 & 39.49 & 1.52 & 1.57 & 0.28 & 0.244 & 0.046 & 930 & 28 & 3360 & 169 \\
\hline JUN & 241 & 63 & 53.9 & 15.0 & 0.202 & 0.031 & 4.76 & 0.59 & 15.07 & 0.52 & 0.60 & 0.09 & 0.124 & 0.021 & 404 & 11 & 2174 & 105 \\
\hline JUL & 2884 & 1424 & 378.9 & 182.5 & 0.916 & 0.286 & 25.45 & 5.84 & 40.70 & 2.21 & 6.07 & 1.79 & 1.296 & 0.404 & 834 & 32 & 2830 & 156 \\
\hline AUG & 48 & 10 & 11.3 & 3.2 & 0.053 & 0.007 & 1.48 & 0.15 & 4.91 & 0.15 & 0.14 & 0.02 & 0.029 & 0.004 & 206 & 5 & 1470 & 68 \\
\hline SEP & 26 & 5 & 6.4 & 2.0 & 0.028 & 0.004 & 0.96 & 0.10 & 3.43 & 0.10 & 0.08 & 0.01 & 0.020 & 0.002 & 171 & 4 & 1347 & 62 \\
\hline
\end{tabular}

Water year 1999

\begin{tabular}{|c|c|c|c|c|c|c|c|c|c|c|c|c|c|c|c|c|c|c|}
\hline OCT & 24 & 5 & 10.7 & 3.1 & 0.026 & 0.004 & 0.99 & 0.11 & 3.33 & 0.11 & 0.08 & 0.01 & 0.024 & 0.003 & 176 & 5 & 1381 & 66 \\
\hline $\mathrm{NOV}$ & 20 & 5 & 14.3 & 4.1 & 0.037 & 0.006 & 0.91 & 0.10 & 3.02 & 0.10 & 0.06 & 0.01 & 0.021 & 0.003 & 170 & 5 & 1244 & 64 \\
\hline DEC & 27 & 7 & 11.8 & 3.8 & 0.093 & 0.015 & 1.07 & 0.12 & 4.31 & 0.15 & 0.08 & 0.01 & 0.026 & 0.004 & 214 & 6 & 1301 & \\
\hline JAN & 764 & 316 & 96.8 & 42.0 & 1.441 & 0.381 & 12.64 & 2.53 & 38.65 & 2.05 & 2.12 & 0.52 & 0.879 & 0.227 & 841 & 32 & 2215 & 121 \\
\hline FEB & 355 & 93 & 70.4 & 21.8 & 1.195 & 0.200 & 11.34 & 1.42 & 49.02 & 1.81 & 1.39 & 0.20 & 0.578 & 0.088 & 1098 & 33 & 2866 & 155 \\
\hline MAR & 251 & 75 & 72.0 & 26.8 & 0.783 & 0.134 & 12.21 & 1.60 & 47.57 & 1.77 & 1.34 & 0.21 & 0.355 & 0.058 & 1193 & 36 & 354 & 178 \\
\hline APR & 198 & 45 & 49.8 & 15.5 & 0.452 & 0.069 & 9.48 & 1.07 & 34.99 & 1.19 & 0.94 & 0.12 & 0.180 & 0.024 & 1016 & 28 & 3217 & 164 \\
\hline MAY & 111 & 25 & 20.3 & 6.2 & 0.230 & 0.034 & 4.74 & 0.53 & 15.95 & 0.54 & 0.46 & 0.06 & 0.087 & 0.012 & 536 & 15 & 2441 & 122 \\
\hline JUN & 29 & 6 & 6.3 & 1.9 & 0.100 & 0.015 & 1.58 & 0.17 & 4.80 & 0.16 & 0.14 & 0.02 & 0.033 & 0.004 & 199 & 5 & 1496 & \\
\hline JUL & 15 & 3 & 3.8 & 1.2 & 0.062 & 0.009 & 0.97 & 0.10 & 2.62 & 0.08 & 0.08 & 0.01 & 0.021 & 0.003 & 131 & 3 & 1186 & \\
\hline AUG & 8 & 2 & 1.6 & 0.6 & 0.031 & 0.005 & 0.58 & 0.06 & 1.63 & 0.05 & 0.04 & 0.00 & 0.011 & 0.001 & 103 & 3 & 1026 & \\
\hline SEP & 5 & 1 & 1.1 & 0.5 & 0.018 & 0.003 & 0.43 & 0.05 & 1.28 & 0.04 & 0.03 & 0.00 & 0.009 & 0.001 & 94 & 3 & 982 & \\
\hline 1 & & 83 & & & 4.468 & 0.875 & 56.94 & 7.86 & 07.17 & 8.05 & 576 & 1.17 & 2.224 & 420 & 5771 & 174 & 709 & \\
\hline
\end{tabular}


Appendix. (continued) Estimated monthly loads and associated error for nine constituents at four sites in the Irondequoit Creek basin and at four sites in western Monroe County, N.Y., water years 1997-99.

\begin{tabular}{|c|c|c|c|c|c|c|c|c|c|c|c|c|c|c|c|c|c|c|}
\hline \multirow[b]{2}{*}{ Month } & \multicolumn{2}{|c|}{$\begin{array}{c}\text { Total } \\
\text { suspended } \\
\text { solids }\end{array}$} & \multicolumn{2}{|c|}{$\begin{array}{c}\text { Volatile } \\
\text { suspended } \\
\text { solids }\end{array}$} & \multicolumn{2}{|c|}{$\begin{array}{c}\text { Ammonia } \\
\text { nitrogen as } \\
\mathrm{N} \text {, dissolved }\end{array}$} & \multicolumn{2}{|c|}{$\begin{array}{c}\text { Ammonia }+ \\
\text { organic } \\
\text { nitrogen as } \\
\mathrm{N}, \text { total }\end{array}$} & \multicolumn{2}{|c|}{$\begin{array}{l}\text { Nitrite }+ \\
\text { nitrate as } \mathrm{N}, \\
\text { total }\end{array}$} & \multicolumn{2}{|c|}{$\begin{array}{c}\text { Total } \\
\text { phosphaous, } \\
\text { as P }\end{array}$} & \multicolumn{2}{|c|}{$\begin{array}{c}\text { Ortho- } \\
\text { phosphate } \\
\text { as P, } \\
\text { dissolved }\end{array}$} & \multicolumn{2}{|c|}{$\begin{array}{l}\text { Chloride, } \\
\text { dissolved }\end{array}$} & \multicolumn{2}{|c|}{$\begin{array}{l}\text { Sulfate, } \\
\text { dissolved }\end{array}$} \\
\hline & Load & Error & Load & Error & Load & Error & Load & Error & Load & Error & Load & Error & Load & Error & Load & Error & Load & Error \\
\hline \multicolumn{19}{|c|}{ Honeoye Creek at Honeoye Falls (04229500) } \\
\hline \multicolumn{19}{|c|}{ Water year 1998} \\
\hline OCT & - & -- & - & - & -- & -- & -- & -- & -- & -- & -- & -- & -- & -- & -- & -- & -- & -- \\
\hline NOV & $\ldots$ & -- & - & - & -- & -- & -- & -- & -- & -- & -- & -- & -- & -- & -- & -- & -- & -- \\
\hline DEC & $\ldots$ & -- & - & - & -- & -- & -- & -- & -- & -- & -- & -- & -- & -- & -- & -- & -- & -- \\
\hline JAN & - & -- & - & - & -- & -- & -- & -- & -- & -- & -- & -- & -- & -- & -- & -- & -- & -- \\
\hline FEB & - & -- & - & - & -- & -- & -- & -- & -- & -- & -- & -- & -- & -- & -- & -- & -- & -- \\
\hline MAR & - & -- & - & - & 0.196 & 0.044 & 14.61 & 1.85 & 34.45 & 12.70 & 2.47 & 0.33 & 0.565 & 0.073 & 1115 & 62 & 792 & 68 \\
\hline APR & - & -- & - & - & 0.173 & 0.032 & 8.32 & 0.88 & 3.60 & 1.00 & 1.27 & 0.15 & 0.222 & 0.023 & 554 & 25 & 443 & 31 \\
\hline MAY & - & -- & - & - & 0.131 & 0.023 & 4.57 & 0.51 & 1.45 & 0.45 & 0.89 & 0.12 & 0.177 & 0.022 & 269 & 12 & 211 & 15 \\
\hline JUN & - & -- & - & -- & 0.019 & 0.003 & 0.66 & 0.07 & 0.27 & 0.07 & 0.10 & 0.01 & 0.030 & 0.003 & 44 & 2 & 32 & 2 \\
\hline JUL & - & -- & - & - & 0.089 & 0.020 & 5.34 & 0.73 & 3.66 & 1.43 & 1.41 & 0.24 & 0.299 & 0.046 & 186 & 11 & 153 & 13 \\
\hline AUG & - & -- & - & - & 0.005 & 0.001 & 0.25 & 0.03 & 0.07 & 0.02 & 0.03 & 0.00 & 0.009 & 0.001 & 14 & 1 & 14 & 1 \\
\hline SEP & - & -- & & - & 0.003 & 0.001 & 0.15 & 0.02 & 0.03 & 0.01 & 0.02 & 0.00 & 0.007 & 0.001 & 11 & 1 & 13 & 1 \\
\hline Total & - & -- & & - & 0.616 & 0.124 & 33.90 & 4.09 & 43.53 & 15.68 & 6.19 & 0.85 & 1.309 & 0.169 & 2193 & 114 & 1658 & $\overline{131}$ \\
\hline \multicolumn{19}{|c|}{ Water year 1999} \\
\hline OCT & $\ldots$ & -- & & - & 0.003 & 0.001 & 0.19 & 0.02 & 0.02 & 0.01 & 0.02 & 0.00 & 0.008 & 0.001 & 19 & 1 & 21 & 1 \\
\hline NOV & - & -- & & - & 0.007 & 0.002 & 0.29 & 0.03 & 0.02 & 0.01 & 0.03 & 0.00 & 0.008 & 0.001 & 32 & 2 & 30 & 2 \\
\hline DEC & $\ldots$ & -- & & - & 0.021 & 0.004 & 0.50 & 0.06 & 0.06 & 0.02 & 0.07 & 0.01 & 0.012 & 0.001 & 56 & 3 & 45 & 3 \\
\hline JAN & - & -- & & - & 0.148 & 0.045 & 4.85 & 0.95 & 13.80 & 7.67 & 1.59 & 0.40 & 0.257 & 0.058 & 400 & 31 & 252 & 29 \\
\hline FEB & - & -- & & - & 0.109 & 0.022 & 3.61 & 0.44 & 11.41 & 3.65 & 0.65 & 0.09 & 0.118 & 0.016 & 432 & 23 & 274 & 22 \\
\hline MAR & - & -- & & - & 0.233 & 0.048 & 9.19 & 1.13 & 11.73 & 3.86 & 1.48 & 0.21 & 0.174 & 0.022 & 805 & 42 & 546 & 43 \\
\hline APR & - & -- & & - & 0.221 & 0.036 & 5.88 & 0.59 & 2.24 & 0.62 & 0.81 & 0.09 & 0.082 & 0.008 & 493 & 22 & 368 & 25 \\
\hline MAY & - & -- & & - & 0.102 & 0.019 & 1.83 & 0.22 & 0.41 & 0.13 & 0.29 & 0.04 & 0.035 & 0.004 & 146 & 7 & 108 & 8 \\
\hline JUN & - & -- & & - & 0.008 & 0.001 & 0.14 & 0.02 & 0.04 & 0.01 & 0.02 & 0.00 & 0.004 & 0.000 & 13 & 1 & 8 & 0 \\
\hline JUL & - & -- & & - & 0.003 & 0.001 & 0.08 & 0.01 & 0.03 & 0.01 & 0.01 & 0.00 & 0.002 & 0.000 & 6 & 0 & 4 & 0 \\
\hline AUG & - & -- & & - & 0.003 & 0.001 & 0.09 & 0.01 & 0.02 & 0.01 & 0.01 & 0.00 & 0.002 & 0.000 & 6 & 0 & 5 & 0 \\
\hline SEP & - & -- & & - & 0.002 & 0.001 & 0.08 & 0.01 & 0.01 & 0.00 & 0.01 & 0.00 & 0.002 & 0.000 & 8 & 0 & 8 & 0 \\
\hline Total & - & -- & & - & 0.860 & 0.181 & 26.73 & 3.49 & 39.79 & 16.00 & 4.99 & 0.84 & 0.704 & 0.111 & 2416 & 132 & 1669 & 133 \\
\hline
\end{tabular}


Appendix. (continued) Estimated monthly loads and associated error for nine constituents at four sites in the Irondequoit Creek basin and at four sites in western Monroe County, N.Y., water years 1997-99.

\begin{tabular}{|c|c|c|c|c|c|c|c|c|c|}
\hline & $\begin{array}{c}\text { Total } \\
\text { suspended } \\
\text { solids }\end{array}$ & $\begin{array}{c}\text { Volatile } \\
\text { suspended } \\
\text { solids }\end{array}$ & $\begin{array}{c}\text { Ammonia } \\
\text { nitrogen as } \\
\mathrm{N} \text {, dissolved }\end{array}$ & $\begin{array}{c}\text { Ammonia + } \\
\text { organic } \\
\text { nitrogen as } \\
\mathrm{N} \text {, total }\end{array}$ & $\begin{array}{c}\text { Nitrite }+ \\
\text { nitrate as } \mathrm{N}, \\
\text { total }\end{array}$ & $\begin{array}{c}\text { Total } \\
\text { phosphaous, } \\
\text { as } P\end{array}$ & $\begin{array}{c}\text { Ortho- } \\
\text { phosphate } \\
\text { as P, } \\
\text { dissolved }\end{array}$ & $\begin{array}{l}\text { Chloride, } \\
\text { dissolved }\end{array}$ & $\begin{array}{l}\text { Sulfate, } \\
\text { dissolved }\end{array}$ \\
\hline Montl & Load & Load & Frror & I oad & Load & Frror & 10 & & \\
\hline
\end{tabular}

\section{Black Creek at Churchville (04231000)}

\section{Water year 1998}

\begin{tabular}{|c|c|c|c|c|c|c|c|c|c|c|c|c|c|c|c|c|c|c|}
\hline OCT & -- & -- & -- & -- & -- & -- & -- & -- & -- & -- & -- & -- & -- & -- & -- & -- & -- & -- \\
\hline NOV & -- & -- & -- & -- & -- & -- & -- & -- & -- & -- & -- & -- & -- & -- & -- & -- & -- & -- \\
\hline DEC & -- & -- & -- & -- & -- & -- & -- & -- & -- & -- & -- & -- & -- & -- & -- & -- & -- & -- \\
\hline JAN & -- & -- & -- & -- & -- & -- & -- & -- & -- & -- & -- & -- & -- & -- & -- & -- & -- & -- \\
\hline FEB & -- & -- & -- & -- & -- & -- & -- & -- & -- & -- & -- & -- & -- & -- & -- & -- & -- & -- \\
\hline MAR & -- & -- & -- & -- & -- & -- & -- & -- & -- & -- & -- & -- & -- & -- & -- & -- & -- & -- \\
\hline APR & -- & -- & -- & -- & 0.143 & 0.030 & 5.81 & 0.50 & 20.09 & 2.58 & 0.39 & 0.04 & 0.079 & 0.010 & 556 & 19 & 1716 & 104 \\
\hline MAY & -- & -- & -- & -- & 0.280 & 0.058 & 7.63 & 0.74 & 16.21 & 2.38 & 0.80 & 0.11 & 0.154 & 0.025 & 509 & 18 & 1790 & 68 \\
\hline JUN & -- & -- & -- & -- & 0.189 & 0.038 & 4.48 & 0.45 & 5.79 & 0.88 & 0.66 & 0.10 & 0.174 & 0.034 & 276 & 9 & 1142 & 75 \\
\hline JUL & -- & -- & -- & -- & 0.154 & 0.033 & 5.48 & 0.52 & 6.75 & 0.98 & 0.86 & 0.12 & 0.237 & 0.038 & 312 & 11 & 1286 & 47 \\
\hline AUG & -- & -- & -- & -- & 0.078 & 0.017 & 2.49 & 0.25 & 3.36 & 0.56 & 0.30 & 0.04 & 0.061 & 0.010 & 149 & 5 & 772 & 36 \\
\hline SEP & -- & -- & -- & -- & 0.066 & 0.013 & 1.48 & 0.12 & 2.01 & 0.25 & 0.14 & 0.02 & 0.027 & 0.003 & 106 & 3 & 610 & 34 \\
\hline Total & -- & -- & -- & -- & 0.910 & 0.189 & 27.37 & 2.58 & 54.21 & 7.63 & 3.15 & 0.43 & 0.732 & 0.120 & 1908 & 65 & 7316 & $\overline{364}$ \\
\hline
\end{tabular}

\section{Water year 1999}

\begin{tabular}{|c|c|c|c|c|c|c|c|c|c|c|c|c|c|c|c|c|c|c|}
\hline OCT & -- & -- & -- & -- & 0.055 & 0.012 & 1.12 & 0.10 & 1.65 & 0.22 & 0.09 & 0.01 & 0.021 & 0.003 & 104 & 4 & 569 & 43 \\
\hline NOV & -- & -- & -- & -- & 0.062 & 0.014 & 1.18 & 0.11 & 1.89 & 0.26 & 0.09 & 0.01 & 0.024 & 0.003 & 127 & 5 & 651 & 39 \\
\hline DEC & -- & -- & -- & -- & 0.091 & 0.021 & 1.19 & 0.11 & 2.11 & 0.29 & 0.10 & 0.01 & 0.028 & 0.004 & 120 & 4 & 606 & 185 \\
\hline JAN & -- & -- & -- & -- & 0.327 & 0.096 & 12.59 & 1.91 & 42.05 & 9.51 & 1.79 & 0.38 & 0.836 & 0.221 & 618 & 33 & 1593 & 135 \\
\hline FEB & -- & -- & -- & -- & 0.319 & 0.074 & 11.27 & 1.09 & 41.12 & 5.90 & 1.24 & 0.17 & 0.400 & 0.062 & 761 & 28 & 2062 & 135 \\
\hline MAR & -- & -- & -- & -- & 0.221 & 0.049 & 10.92 & 1.07 & 31.92 & 4.57 & 0.96 & 0.13 & 0.198 & 0.032 & 920 & 34 & 2407 & 152 \\
\hline APR & -- & -- & -- & -- & 0.222 & 0.045 & 5.19 & 0.43 & 9.66 & 1.20 & 0.46 & 0.05 & 0.045 & 0.006 & 468 & 15 & 1744 & 102 \\
\hline MAY & -- & -- & -- & -- & 0.249 & 0.050 & 2.61 & 0.22 & 2.58 & 0.33 & 0.31 & 0.04 & 0.026 & 0.003 & 209 & 7 & 1057 & 62 \\
\hline JUN & -- & -- & -- & -- & 0.094 & 0.019 & 0.73 & 0.06 & 0.37 & 0.05 & 0.10 & 0.01 & 0.015 & 0.002 & 64 & 2 & 377 & 22 \\
\hline JUL & -- & -- & -- & -- & 0.035 & 0.008 & 0.36 & 0.03 & 0.14 & 0.02 & 0.05 & 0.01 & 0.010 & 0.001 & 33 & 1 & 208 & 12 \\
\hline AUG & -- & -- & -- & -- & 0.046 & 0.011 & 0.65 & 0.07 & 0.37 & 0.07 & 0.09 & 0.01 & 0.011 & 0.002 & 46 & 2 & 309 & 21 \\
\hline SEP & -- & -- & -- & -- & 0.040 & 0.008 & 0.41 & 0.03 & 0.21 & 0.03 & 0.04 & 0.00 & 0.006 & 0.001 & 35 & 1 & 250 & 14 \\
\hline Total & -- & -- & -- & -- & 1.761 & 0.407 & 48.22 & 5.24 & 134.07 & 22.45 & 5.32 & 0.83 & 1.620 & 0.340 & 3505 & 136 & 11833 & 222 \\
\hline
\end{tabular}

